University of Rhode Island

DigitalCommons@URI

Open Access Master's Theses

1961

\title{
A Comparison of the Characteristics and Scholastic Achievement Between the Transient and Permanent Children in Grades Four, Five and Six in North Kingstown
}

Gabriella Hamilton Adams

University of Rhode Island

Follow this and additional works at: https://digitalcommons.uri.edu/theses

\section{Recommended Citation}

Adams, Gabriella Hamilton, "A Comparison of the Characteristics and Scholastic Achievement Between the Transient and Permanent Children in Grades Four, Five and Six in North Kingstown" (1961). Open Access Master's Theses. Paper 832.

https://digitalcommons.uri.edu/theses/832

This Thesis is brought to you for free and open access by DigitalCommons@URI. It has been accepted for inclusion in Open Access Master's Theses by an authorized administrator of DigitalCommons@URI. For more information, please contact digitalcommons-group@uri.edu. 


\section{A COMPARISON OF THE CHARACTERISTICS AND SCHOLASTIC \\ AGEI EVEMENT BETWEEN THE TRANSIENT AND PERMANTENT \\ CHILDREN IN GRADES FOUR, FIVE, AND SIX IN \\ NORTH KINGSTOWI}

BI

GABRIETLIA HAMILTON ADAMS

$\triangle$ THESIS SUBAITTED IN PARTIAL FULFIILIMENT OF THE REQUIREMENTS FOR THE DEGREE OF

MASTER OF SCIEANCE

IN

EDUCATION

UNIVERSITY OF RHODE ISLAND

1961 
MASTER OF SCIEACE THESIS

or

GABRIEIICA HAMILTON ADAMS

Approved:

Major Professor

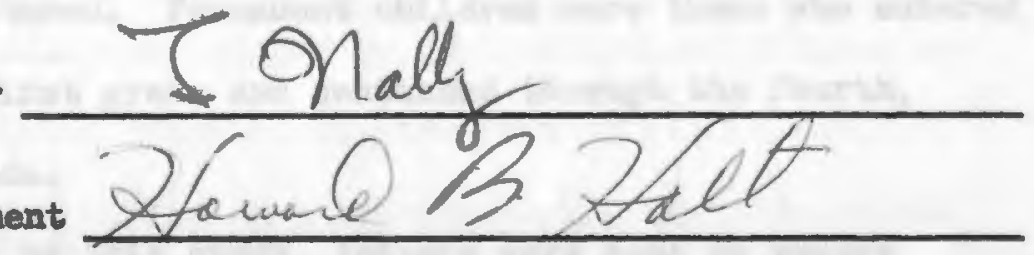

Head of Department

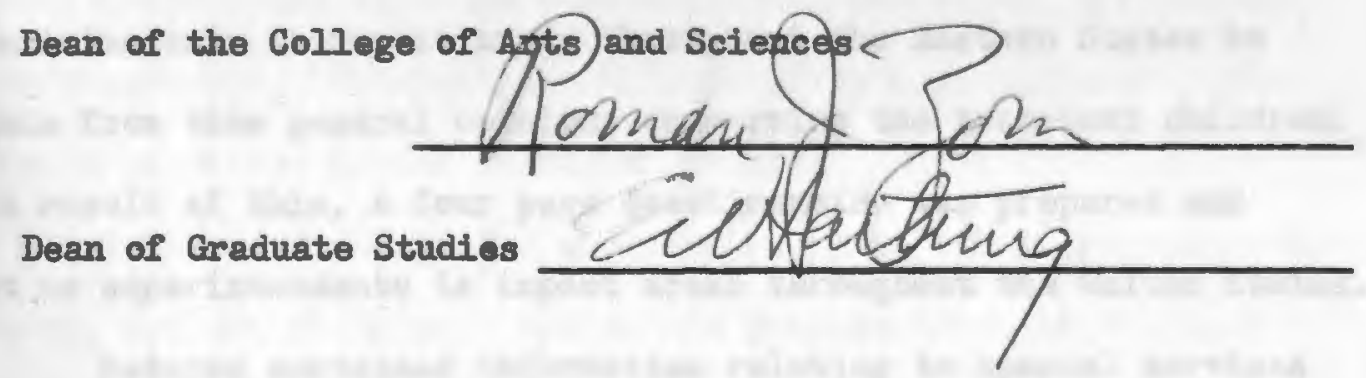

UNIVERSITY OF RHODE ISIAND

1961 


\section{ABSTRACT}

The problem involved in this thesis was to determine if any significant difference in scholastic achievement and characteristics existed between the transient and permanent children in grades four through six in North Kingstorm. Transient children were those who had been enrolled in the North Kingstorm School System for one year and a half or less when the Iowa Tests of Basic Skills were administered. Permanent children were those who entered the systen in the first grade and continued through the fourth, fifth, or sixth grade.

Preliminary to this atudy, letters were sent to twelve suparintendents in impact areas throughout the Eastern States to obtain from them genaral opinions concerning the transient children. As a result of this, a four page queationnaire was prepared and sent to superintendents in impact areas throughout the United States.

Returns contained information relating to special services rendered the transient child, the availability of records, opinions concerning the achievement of the transient ohild in reading, the number of ehildren in a classroen, arithmetic, knowledge of social studies, resources, adaptability, and miscellaneous information of a like nature. 
The Iowa Tests of Basic Skills were administered to all the chilldren in grades four through six. Results from a statistical analysis of these tests revealed no significant differences between the two groups. Both groups scored above the national norms in all tests except map reading in grade five in the transient group and map reading and arithmetic problem solving in grade four in the permanent group.

Writing samples were obtained by having each child write a short couposition. These writing samples were rated on a four point scale. These ratings were compared through the chi-square tochnique. No significant differences were found.

Characteristics were marked by the teachers on a three and four point rating scale. Results obtained from a statistical analysis disclosed few differences in characteristics. Transient children were found to be more resourceful, adaptable, persistent, and enthusiastic. Punctuality and shyness were significant diffarences possessed by the permanent groups.

Pertinent information was obtained from office records, the teacher, and the children. Due to the preponderance of children coming from broken homes in the transient group, statistical tables were made of groups from broken homes and non-broken homes. Iransient and permament children were grouped together. This analysis achibited the children from broken homes to be less alert, less creative, less popular, and less honest. Deficiencies also occurred in attitude, verbal expression and work habits. The study of enly transient children from broken homes and yph-broken homes revealed the children from broken homes to be less popular, less punctual, 
and less honest. Doficiencies also eccurred in attitude and work habits.

No statistical significant differences were revealed in the number of children repeating a grade between the transient and permanent groups of children. Likewise, no difference was disclosed in their participation in community activities.

An analyais of the writing samples of the transient children showed their concerns relating to changing schools. These children, on the whole, were concerned about moeting new friends and leaving old friends. They worried about the differences in their school work. Yany felt a change at the beginning of the year was all right but did not care for a change during the year. Many felt that changing schools was an adventure and that it took little time to adjust to a new school situation.

The socio-econoulc status of these transient and pernanent children undorbtedly had some bearing on the results of this study. Studies of children from Puerto Rican families, Hexican fanilies, and children from migratory families may be rastly different.

As this study pertained only to children in grades four through six, the writer trusts it will be an incentive to someone to make a study of the children in grades one through three. It is possible that results obtained may be significantly different. 


\section{ACKNOWLEDEMINS}

To Doctor Thomas P. Hally, who was wy najor advisor for this thes1s, I am indebted for many hours of helprul guidance and spervision. Nlso, I am indebted to Doctor Irving 1. Spaulding and Mr. Edmund J. Farrell for their suggestions and assistance.

I ackouledge with gratitude the co-operation recelved from the prineipals and teachers in grades, four, five, and $8 i x$ in North Kingstorm. My thanics are extended to Mr. Hiran A. Davis, Hss M. Corinne Barden, and Mr. Burton Froberg for placing at ny disposal data from children's records and peruitting me to administer the tests in each grade.

I am also indebted to the many superintendents who took time from their busy day to answer the lengthy questionnaire and forward it to me imediately.

To all others, especially my seeretary, Roberta Spink, who have been of assistance to me, I am deeply grataful. 
TABLE OF CONTENTS

Page

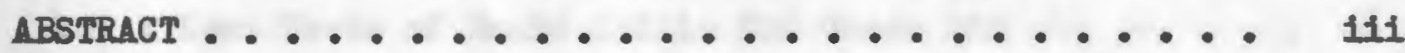

ACKNOWLDGMETS ................. V1

LIST OF TABLES ....................... vili

Chapter

I. STATESENT OF THE PROBLEA ........... 1

II. REVIEW OF THE IITERATURE ........... 19

III. METHODS AND PROCEDURES ............ 43

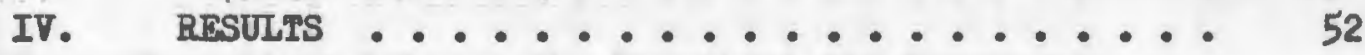

v. CONCLUSIONS AND RECOMLENDATIONS ........ 94

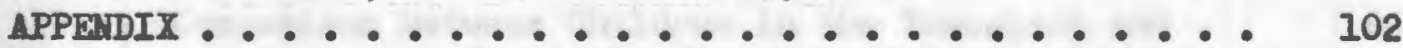

BIBLIOCRAPHY ................................ 149 


\section{LIST OF TABLES}

Table

1. Number of Different Schools Transient Children have

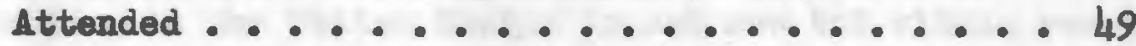

2. Iorra Tests of Besic Skills for Grade Pour . . . . 62

3. Iowa Tests of Basic Skills for Grade Five ..... 64

4. Iowa Tests of Basic Skills for Grade Six ...... 66

5. Comparison of the Characteristics between the Transient and Permanent Children in Crades Four,

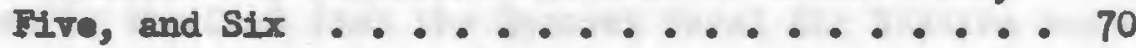

6. Comperison between Broken Homes and Mon-Broken

Homes in Transient and Permanent Chtldren ... 78

7. Broken Homes and Hon-Broken Homes - Transient and

Permanent ............. 80

8. Comparison of the Characteristics Between Transient

Children frem Broken Homes and Non-Broken

Hones ............. 84

9. Comparison between the Transient and Permanent

Children in Regard to Repeating A Grade .... 87

10. Comparison between Children in the Transient and

Permanent Groups in Regard to Entering Outside

Activities ................ 88

11. Comparison of Writing Samples between Permanent

and Iransient Children .......... 89 


\section{STATEMEAT OF THE PROBLEM}

I. Introduction (Problen of Iransiency)

Iransiency in the United States is not new but within recent years it has become a comnon occurrence. It is a problon facing schools and commoities. Fren the moving man is cencerned, for Mocomackl states some helpful suggestions to parants when moving from one area to another. Iranalonoy is quite typical of North Fingstown, due to the fact that the Gronset Naval Iir Station and Davisville Construction Battalion are situated here.

To present a clear picture of the backgroand and problems faced by the Town of Morth Kingstom and the people in this torm, this chaptar is uritten. It is hoped that the information contained harein will present a picture of an old colonial village steeped in tradition and nost conservative.

Quite suddenly, the peeple within the Town were confronted with an influx of Iavy Persennel, who through travel and cxperience, had acquired 2 broad background of this country and various parts of the world. The stationary childree at once faced a group of children from almost orory state in the United States. The permanent children took their places with them in the school systom and commaity and competed with them.

Ipatricle McCormack, When Moving Prepare Children for Change in Thoir Enviromont", (No. 36; Hone Edition; Prov;, R. I.: The Brening Belletin), Vol. XCIX, (Konday, Febrwary 13, 1961), p. I6. 
An historic introduction to the tewn is provided by the Jowrnal Bolletin 1959 Mmanac, 1 as follows:

Incorporated Oet. 28, 1674. First settlement, 1641. Incorperated in 1674, under the name of Kings Iowne, as the seventh tom in the colony. Inserporation reaffirmed in 1679. Name changed to Rochester, June 23, 1686, bat was restored in 1689. Kings Towne divided into Jorth Kingstom and South Kingstorm, February, 172223. The act provided that North Kingstorm shovld be the eldest torm. $44.15 \mathrm{sq}$. ni.

Educationally, the torm has progressed trenendously in the last tro centuries. Education begen in 1800. According to the friters Progran of the W. P. A., 2 the first aeadeng in Rhode Island was estabIIshed in the village of Whakford and was knom as the Wishington 1eadary. The Wickford Gramar Sohool stands on this present site today.

\section{Setting of Probles}

In V1ew of the fact that North Kingstorm is in a derinitely transient area, the problen of mobility in the school population is outstanding.

North Kingstem is situated on Jarragansett Bay in the State of Rhode Ialand. It is bounded on the north by the Town of East Greenrich, on the south by the Town of South Kingstorm and on the west by the Town of Rreter. The east boundary 1s Nerragansett Bay, North Kingstorm having several wiles of coastline.

The center of the Torm is riseiford, an old New Fngland Village. Previous to the 1938 muricane, all the streets were lined with beautiful otately alm trees. The steps of the houses on Main Street are flush

IJomral Balletin 1959 Almanac, 1 Rhode Irland Reference Book, Soventy-1wrd Trenal Leition; (Prov., R. I.: The Providence Journal Eomany), p. 44 .

2Rhode Island, Wiriters Program of the W. P. A., Mran Mass. Iine to com. Inine," (Bosten: Houghton VifIIin Co.), p. 333. 
with the sidewalk and many of the trunks of these eln trees practically touch the stairs leaving vary little sidewalk. The residences in the village are very old colonial dwellings, some dating back to the eighteenth century. Houses are close togethor with the back Jards rwaning down to the shoreline.

Beautiful colonial doorways previde an ever present interest to Nisitors. The Writers Progran of the W. P. $1{ }^{1}$ rafers to these drellings as a rich field for students of early American architecture. On this short Main Street, there are no less than twenty houses built between 1728 and 1804. On adjoining or near-by streets, there are more than forty other old realdences, most of then dating from the eighteenth century.

Before the 1938 hurricane and the establishment of the guons at Iaval fir Base, the town had no water sapply, each individual house having a wall. In the center was a town well where one night see someone draring water at 211 times of the day. With the advent of the 1938 burricane, the sea water rushed into the torn, inundating many houses and making the water from the wells absolutely useless. This incident brought quick action from the town fathers and the people voted for the installation of tom water. During the time between the hurricane and the installation of town water, the people were supplied with water from a fire truck which went from house to house.

Iside from Hiakford, the center, the rest of the town included eight other small villages, most of which included a store, a rural sahool, and a post office which was usually located in the store. 
These villages also included woolen mills, a narrow fabric mill, and farm lands - the main product from the farms being potatoes.

Previons to 1932, rural schools deminated the Torm. In the villages of Saunderstown, Slocum, Quidnessett, and Belleville were to be found one room schools, most educating children in grades one through eight. The villages of Davisville, Hamilton and Allenton had two room buildings and Lafayette a three room building. This latter is now the smallest school in Town. Wickford, being the center, housed the high school and grammar school in a two floor nine room building. Being a sparsely popolated Town, except for the center, Wlckford, everyone seemed to know everyone else. A large proportion of the population were descendents of old New Fngland families. Most of the people worked in the mills, engaged in fishing, or "followed the shore". There was little opportmity for college educated people in the Town to find a place of employment. These residents of the town were average people, taking pride in the town and its. people. It was possible while walling in the center of the village or shopping in the stores to chat with all the people, for evergone knew all the neighbors and "gossip of the day".

The one exception was the surmer time when an influx of summer residents saturated the area. Many of these sumer residents were quite wealthy and added much to the town. Some have become quite active in torm affairs during recent jears. On the whole, the permanent residents were of average middle-class families with practically none of non-Mnglish speaking parentage.

According to White, 1 Wickford had many of the earnarks of an

ICol. Hunter C. White, "Wlickford and Its Old Houses", Old Wickford, (North Kingstorm, R. I.: The Main Street Assoc., May, I960), p. 18. 
oighteenth century village until the vineteen thirties. It remained about the same in its colonial spirit and genaral appearance. What in provements had been made were sporadic and were merely an atterut to hring some of the material comforts of a modern age to an ancient Village without destrojing its character and charm. Hickford was an Intensely conservative village and what changes had been adopted were made anly after long consideration and delay.

Not far fraa the village the construction of the Quonset Naval Air Station began in 1940. The population grouth began with the influx of Hary parsonnel and civilian workers into this colonial setting. Ihe popalation of the town aty-rooketed in the ten years between 1940 and 1950. In the Journal-Bulletin 1959 Nimanac, I the popnlation of Jorth Kingstom for 1940 , is listed as baing 4,604. In 1950, the pepriation is Iisted as 14,810 , a gain of 10,206 or 221.7 par cent. The grouth af pepratation eased between 1950 and 1960. However, the Providence Brening Baletin2 lists the pepulation in 1960 as 21,604 , a gain of 46 per cent. This created a housing and school shortage. The scheol shortage was lessened scmewhat by an addition to the Senior-Junier High Sohool, the Illelford Grammar School and the erection of a ten room chonset Filementary School. Since 1950, an elghtecn roon elementary school was erected In the north end of torm and an eight room elementary school at the Hockins Park Howsing Derelopment. The Iavy rented the Construction Battalion Hese Hall to the town which added eighteon more classroons.

IJouran Bulletin 1959 11manac, A Rhode Island Reference Book,

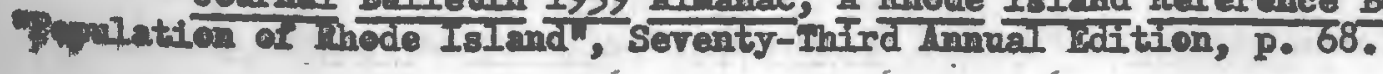

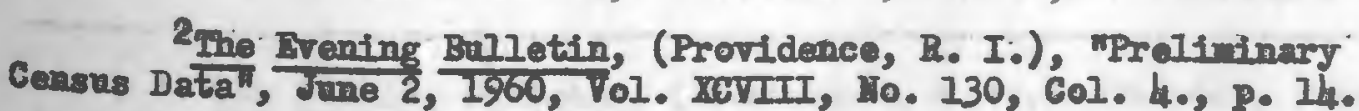


In September, 1959, the new Senior High was opened and the old JuniorSenior High was used exclusively as a Junior High. To alleriate crowded conditions in the present schools and take care of the future growth of the school population, the Providence Balletinl states that the North Kingatown School Committee adopted a $\$ 1,236,000$ proposal to build two new elementary schools and additions to two schools by 1962. The school population is still growing faster than schools can be constructed. This situation is confusing to the new parent who may have ehildren entering a fourth grade, a fifth grade, a sixth and a seventh grade. To accomplish the registration for each child, the parent may possibly have to register at four different schools, for all but one of the elementary schools cannot take care of any chtldren above the fourth grade. In fact, the smallest school in torm, three rooms, which in 1930 was the second largest, can take care of only the first three grades.

The population grewth way have slowed down but the town 1s atill confronted every year with a vast number of transient chtldren who will enter the schools. The questions are always, "What will the school enrollment be next September? Are there enough rooms araflable if some grade is extremaly large?" Registration day is a week before the opening of school. If held any earlier or in June, it would be inpossible to formate classes for the coming year. The shifting population would hinder this. School officials wait to discover what the week before school opening will bring. The turnover in school pepolation during the year is tremendous. Pettar ${ }^{2}$ gives the enroll-

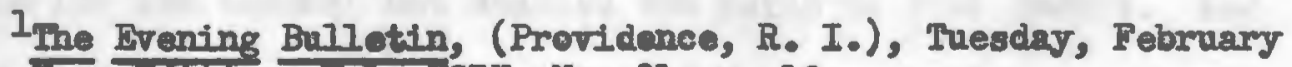
7, 1961, Home Edition, Vol. XCIX, No. 31, p. 19.

PRuth E. Potter, "Table VI", Statistical Tables, (Rhode Island: Dept. of Education, 1958-1959). 
ment of the elementary schools in North Kingstown for the year 19581959 as 2,177 , and the average membership as $1,764.76$, making a difference of 412.24 between the enroliment and the avarage memborship or a 23.36 per cent turnover during the year. This actually means that twenty-three children out of every one hundred who entered the schools in September were not there in June. In couparison with another town in this state, Cumberland, which is not an impact area, the turnover was only 3.04 per cent. This turnover in school population is a serious problex. It is, however, interesting, itimalating, and a challonge to the teachers in the syotem.

The mobile school popalation is mainly composed of children of Havy persomnel, for many of the eivilian workers at the base have established homes in town, some having been here for a period of twenty years. They're almost out of the "carpet-bagger" class now. laturally this influx of school population has resulted in an acute teacher shortage. Many of the wives of the Mary personnel began to teach in the schools. This makes for not only mobile school

pepalation but a mobile teacher population. The Navy wives, generally, have been a distinct advantage to the school system. Transiency is natural to them and they are interested in the mobile child. Some of the ahildrens' parents may be in the same squadron or live in the same Havy housing or private development. This gives the children a sense of security. For example, there was the case of a child in the fourth grade who upon entrance to school seemed to be entirely lost. His tencher lired in the same apartment house. It was, no doubt, a trying situation for the teacher but enabled the child to feel secure. Had this not been the case, the adjustment of this particular pupil may II pact: an area where a number of military fandlies are
situated. 
have been difficult. Due to the closeness of his teacher, he had something the other children in the room failed to possess.

Wany of the teachers are wires of Naval officers. Being wheh, they have an insight into the difficulties some of the enlisted mens' children have. These teachers have traveled greatly thenselves. They have been, more than once, uprooted from familiar grounds, and traveled to parts of the cowatry or world completely unknown to them. Here they attenpted to make friends and put doum roots horisontally rather than vartically.

The enlisted men's children live in a Havy housing project where the socio-economic pieture is lower than those living outside the projects. The teachers realize the small anount of pay receired by many of these onlisted men and the budgetary problea they face. Consequently, these teachers, along with others, have many times loaned children money to bry lunch or milk.

These nobile teachers have sometimes lived where some of the pupils have resided. They know a little about the schools which these children have attended and what resources the children way have. Several of the teachers have children of their oum; consequently, they have firsthand experience with the difficulties confronting the mobile ahilidren.

The veteran teachers ware faced with a situation quite remote Irom any experienced previously. They took it all in their stride, welcomed the new child, and attempted to discover his assets, schoIastic achievement, and potentials. In so doing, they aided the new child and made hin feel he had a definite place in his new environment. If the child was timid or $a k y$, boastful, a trouble maker, what conld 
best be done for him? The reading groups in an individual classroom grew from three to five or more. Individual work was a must. These veteran teachers along with new teachers coming into the system have had an experience which teachers in stable populated schools miss. After the opening of the Naval Base, the type of person in North Kingstown has changed. Not only was the establishment of the Haval Base responsible for this, but traveling being much simpler today, many families have moved from the cities to the country and commite to their work in other parts of the state. Now families are found in town with names which were foreign to the town a few years ago. Iooling through a school registar today, along with the names of Gardiner, Green, Arnold, and others will be found Maysnarsky, Liello, Bouchard and the like. The school population contains ehildren of Admirals, Captains, Commanders, Lieutenants, and so on down the line. The toin has grown and with it have come many very fine aducated people. Some, after retirement from the Iary, have settled here making it their permanent home and in so doing have contributed much to the torm.

The Providence Evening Balletinl gives a few points on the effect of the Navy Installations in town. The North Kingstown Planning Comission was reviening a thirty-six page report. The surmary of the report made these points:

The Havy has utilized prime industrial waterfront land which exrrently is non-taxable, and which on December 1, 1956, had an

IProvidence Evening Bulletin, "North Kingstown Study Stresses Fffects of Navy Installations", (April. 15, 1960), p. 23. 
assessed valuation of an estimated $\$ 54,260,000$. (The Tax Book 1 for the Town of North Kingstown shows the valuation of. Iand owned by the United States Government to be $\$ 2,235,500$. This is not all waterfront land.)

Because of a constant turnover in certain of its segments, the Havy-connected popralation does not have as much community identification and interest as does the permanent population.

The installations have overburdened the town's school system at times, whereby the system finds itself with a sudden surge in anrollment of Mavy children. As a result, this adds to the difficulty of planning for future school needs.

It has shifted the cost of certain community services which benefit all the people on to those persons who pay taxes in the community.

The report also said that although the Federal Govermment has contributed toward the school costs, the town's expenses in educating "impact" children exceeds funds received from the Federal Government. On the credit side, however, the worksheet noted that establishment of two naval installations was the most significant factor in the town's industrial development.

Prior to their establishment, the report said, the town had very little industrial standing, and, in fact, currently has only twenty-nine acres utilized for private industrial purposes. It also noted that the naval installations have increased employment, and have holped to broaden the town's industrial base.

It is easy to envision the effect the impact of the Havy has had on the town. The center, Lickford, is still an old New Hingland Village, 4ctually there was little room for expansion here, but the outlying parts of the town, especially the north end, have grown by leaps and bounds. For a torm to cope with this rapid expansion is

ITown of North Kingstorm, R. I., Tax Book, "Valuation of Property 
difficult, but North Kingstown has made great strides in the right direction.

The schools are of high quality and school personnel attempt to do ali they can to aid the mobile children in their new enviroment. In the amount of money spent per pupil in the elementary school in 1958-1959, Potter'sl figures show the town ranked ninth in the State. The amount spent per pupil in the elenentary school was $\$ 323.63$.

Classes are kept to a minimum, the average being twenty-five pupils per classroom. This is necessary due to the changover in school popalation. In one school, which approximates one hundred per cent Mary, only two children ay carry over from one grade to another. The teacher is continually being challenged by new pupils entering the system. It is a rare occasion when a grade has the same pupils in June who were there in September. With smaller classes, the teacher is able to devote more of her time to the individual pupil.

Veteran teachers in town were indeed unfamiliar with a transient school population. Through the prevailing years they have become accustomed to this situation. Through their careful guidence, the parents have expreased thoir appreciation of the work accomplished by the students.

It is hoped that this description of the Town of North Kingstorm and the situation it faced may provide some background for a comparison of mobile and stationary children.

\section{The Problem}

The purpose of this study is to discover through testing and

I Iruth E. Potter, "Table VI", Statistical Tables, (Rhode Island: Dept. of Bd., 1958-59). 
questionnaires whether any distinct characteristics or outstanding abilities or disabilities are present in the transient school population in the Town of North Kingstorm, as compared with the stationary ehildren.

Where any armed forces base is located, a vast number of children enter and leave the schools in the loeality during the year. 1 floating population is inevitable with pupils entering schools for a short or indefinite period of time. The previous discussion of the history of Iorth Kingstown clearly reveals that the town is definitely affected in this manner with the presence of the gaonset Haval Lir Station and the Davisville Construction Battalion Installations. Children have been entered in the schools for as short a peried as three days. They then leave, to travel to other parts of the country or outside the country. These children present specific problens. Ortentimes no records come with the children and wast be acquired from the school systen from which they came. Problems arise from the fact that very little or nothing is knorm concerning these children. A considerable anount of time is spent each year determining the charactaristios, and achievements of these pupils.

Lecording to Francis Martin, ${ }^{1}$ it is estimated that trenty-five per cent of our population is on the move. If this is true of the population throughout the country, the situation at armed force bases would seem to be considerably higher.

IV. Importance

It would appear, from the surface, that many problens arise

ITrancis Hartin, "Lobility", Childhood Education, Vol. 34, (September, 1958), pp. 25-28. 
from these transient students. Is this 80 Would the situation be entirely different had the students been enrolled in the sehool system from the beginning? Teachers know the stable childrea. Their records are available; any problans connected with them nay be checked and constantly revierred. Records of eje examinations, audiometer tests, physical disabilities, speech handicaps, and scholarship achievements are arailable. All these must be established for the new child. If the child enrolls for only a short period, it would seem almost useless to spend endless hours checking his physical makeup and scholastic achievement. Iet it must be done.

An example of a single problem may be useful in presenting a clear idea of the difficulties encountered. Johnnie entered third grade in Horth Kingstorm from another state. He at once became a problem to his teacher. Records from the previous school were sent for. Three days after the records were received, Johnnie left to attend school in another state.

The impression that the stable children of school age in the Town of North Kingstown are superior to the floating school population is open to question. How can its validity be assessed unless an intensive study is made? In checking penmanship papers from a specific grade, it might be concluded that the mobile children were better writers than the stable population. For a comparison and conclusion, observations from several children in different grades must be made. How does the transient school population compare with the stable popalation in efficiency, honesty and work habits? Are the transient children as well-adjusted? Do they compare favorably with the stable population? Is their scholastic achievement according to ability up 
to standard? Are they better writers? 171 of these questions may be answered through an intense study of the mobile and transient population.

Vice-Aduiral Hyman G. Rickover, I stated that we should have federal standards in education. One problem this would eliminate for the transient child would be studying the geography and history of a specific country for three years instead of one with the elimination of the other cowntries. Phillips2 states that problems resulting from educational defieiencies should become less important in dealing with the migrant pupil when educational opportunities become more cogralized in different sections of the country.

In social studies it may be assumed that children who have traveled greatly may possess information not available to the stable child. Martin 3 mentions that experiences as members of service fanilies provide a rich resource for school children. These children become the source of important information. How do these experiences compare with those of stable children? Do mobile children present to thoir fellow classmates and teachers items of more interest and value than those of the children remaining in one system?

V. Iinitations

In a public school systan, all children are accepted regardless

IVice-1dmiral Hywan G. Rickover, Meet the Press, January 24, 1960. (Television)

2Beeman N. Phillips, "Impact of Pupil Mobility of the Schools", Fdneational Administration and. Suparvision, Vol. 43, (February, 1957), pp. 101-107.

3rancis Martin, Mobility", Childhood Education, Vol. 34, (September, 1958). p. 25 . 
of their intelligence. Therafore, in this study, intelligence is not 2 factor in determining comparisons. Consequently, all the children anrolled in grades four, Iive, and six were tested, but not all were included in this study.

To include grades one, two and three in this study would have created twice the amount of time included in this stady. The cest of tosting would have been tremendous and arrangements for testing would have been most diffieult. Hore children are enrolled in grades one through three. Using anly grades four through six, over six hundred tests had to be corrected and the same number of characteristics and questions to be tabulated. Those also not included in the study were pupils who did not enter the first grade in this system, but eatered sonetime later and were enrolled more than a year and a half prior to May 1, 1960. In order to be considered transient, the children must have entered the North Kingstom School Systen on or after December I, 1958.

Testing was not done by one person exclusively, but by the various teachers in the system. All teachers administering the tests had had previous experience in testing. The tests from one fifth grade were wisplaced, approxinately thirty of them; therafore, this grade could not be included in the thesis. The scoring was done manually once and not checked.

Characterlstics were marked by the teacher. This could not be considered conclusive evidence for there are possible inaccuracies and aisudgments. This is a comon limitation of the questionnaire tochnique. 
Pertinent information was acquired from school records, the teacher, and the children themselves. It was not easy for some of the mpils to determine how many different schools they had attended. Inaceuracies may have occurred here.

Pemmanship was determined by each child mriting a short composition entitled, "What Changing Schools Means to Me." This device was utilized primarily to obtain a sample of the student's handwriting and at the same time hils immediate thoughts conearning his opinions of changing schools. These were graded by one person.

In the questionnaire sent to fifty superintendents in impact areas throughout the country, the words elementary schools were atilized. The questionnaire, when referring to elementary schools, did not specify grades one through six. A few of the superintendents included grades seven and eight. However, only three superintendents made the questionnaires fall into this category. A few of the questions were left unanswered for reasons unknown to the writer. The majority of the questions, however, were answered and an explanation written under the column remarks.

The letters, sent to the superintendents previous to the miting of this thesis, were designed mainly to obtain a persenal opiniton coacerning the transient child. Inaccuracies may have occurred. For example, a superintendent sent his views concerning all schools in his area. A response from a principal of one school in this area indicated that mch more was done for the transient child than the superintendent realized.

VI. Terms

Flementary School is moant exclusively for grades one through 
six. The words transient and mobile are used exclusively to mean those children who had not been enrolled in the schools of North Kingstown for at least a year and a half prior to Kay 1, 1960. Stable, stationary or permanent are used interchangeably to mean those who enrolled in the first grade in the North Kingstom System, and had continued through the fourth, fifth or sixth grade at the time this study was conducted.

VII. Conclusion

Pupils changing schools present a problem both to the teachers and to the school system. The Nex York Timesl stated that children changing schools are four times as likely to fail a grade as those who stay in one school. This conclusion was reached by a State University of Iowa graduate student, who analyzed the records of 5,128 grade school pupils in 125 Iowra Public Schools. If this is so, the majority of students in North Kingstown schools would be retarded one year. \& study of the children in grades four through six way well bring tö light dominant characteristics and scholastic achievements of these transient children as compared with the child who stays for six years in one educational systax.

Wahlquist2 states that pupils arrive in high school without oufficient reading ability to carry on work at this level. Two of the reasons given were: (I) the movement of pupils to many schools, the interruption of the continuity of the reading program. If all this

\section{IIE York Times, (September 25, 1955), IV-EII.}

2Tahlquist, Arnold ; Campbell, Reller, Sands, "Pupil Accounting",

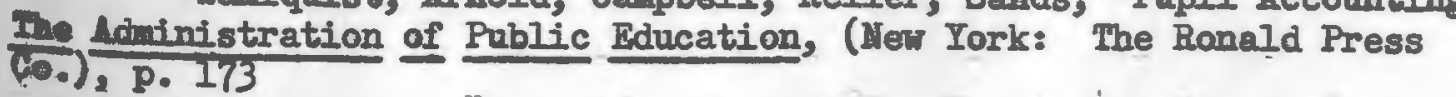


is so, then mobile children are at a distinct disadvantage. It might be concluded that these robile children are motionally upset, below standard in achilevement, and madaptable. However, quite the opposite night be true. With the continusl uprooting of their enviroment, they may possibly be more alert, adaptable, resourceful, democratic, and up to standard in acaderic achievement. Through this stady, the writer hopes to obtain more accurate answers to many of the questions arising from the problen of mobility. 
CHAPTER II

REVIEW OF THE LITERATURE

I. Iiterature

The literature reviewed, pertaining to mobile and transient ebildren, contained mostly opinfons except for studies relating to the mobility of the population of the United States. When this thesis was first formulated in the summer of 1959, nothing could be found concerning a comparisen of a mobile child with a stationary child. More literature was available the following year, but this dealt mainly with the transient child.

Sources of information came from such educational magazines as Eucational Leadership, Educational Administration and Supervision, School Iife, and Childhood Education. Books consulted were The AdminIstration of Public Education, Rhode Island Writers Program of the Hi P. A., Old Wickford, Journal Bulletin 1959 Almanac, and The Principal at Work. Other sources were from current pamphlets, newspapers, and records from the Department of Education, State of Rhode Island.

One excellent source of information was a pamphlet, When Children Move from School to School, published by the Association for Childhood Education International, and an article in Changing TimesThe Kiplinger Magazine. 
The writers of the articles read were concerned about the transient ehild. Ways in which to make his adjustment less complicated were suggested.

Buchmellerl did not make an actual stady of these children but did consult, informally, parents and children to obtain their reaction to the changing of schools. Hammond 2 made a study of the ahievement and adjustment patterns of service-connected children, and Hayes 3 wrote in detail relating what was being accomplished at Fort Campbell, Kentucky, A Strategic Arwy Comand, in making adjustments for these mobile children. Larsent made an extensive study of the affect changing schools have in relation to repeating a grade.

Much of the literature revietred pertained to the increasing mobility of the popralation and the effects this mobility has on a child and the ability of the schools to secure records of the child's work. These writers explained in detail what wust be done to make transition from one school to another with ease.

\section{Iransiency}

Iransiency today is a comonplace occurrence. Fanilies are moving at all periods of the Jear, regardless of the transition the children must make when changing from one school to another.

11. D. Buchmueller, When Children Move from School to School, (Arsociation for Childhood Education International, 1960).

2Prances Proctor Hamond, A Study of the Achievenent and Adjustment Patterns of Service-Connected Children. (Rhode IsIand: iniv. of R. I., 1960).

3Elsie Hayes, "Changing Neighborhood-Changing Schools", Eheational Leadership, (February, 1960).

4Dr. "Robert E. Larsen, New York Times, Section IV-KII, (September 25, 1955). 
Mobility is increasing. Americans are on the move as never before. Several centwries ago, the "Pilgrim", I meaning wanderer, traveled from Fngland to Holland, thence to America to discover for himself a better way of living in keeping with his religious beliefs. These Pilgrims, when once settled in America, were the beginning of the shifting population of the United States of America.

For approximately three hundred fifty years, since the beginning of Mnorica, the poprlation of the United States has been on the move. Freedom of religion and the ideal of each to become an individual himself was the beginning of the trend to move from one area to another. As other areas were discovered, curiosity and a thought that, "The grass is greener elsewhere", continually kept the people on the more.

Iravel was difficult but with the advent of the Conostoga Wagon this was made easier. Families packed their possessions, boarded the wagon, and departed for the West not actually knoring what awaited them at their destination. The spirit of discovery and searching for a better life drelt high in the minds of these Miloneering Americans. Maturally, moving from one place to another did not have the same effects on the children, for education was not madatory as it is today. With compulsory education a rule in all states, children must attend school and adjust to conditions in various schools throughout the country.

Inventions of the train, automobile, and airplane made traveling comparatively easy. Corporations grew, many having plants in various parts of the country. Employees were transferred and the mingfleld, Hassachusetts: Webster's G. \& C. Merriam Co., 1951). 
family moved. Relatives, instead of betng in one particular area, were in other parts of the states from north to south, and east to west.

Phillipsl writes that pupil mobility will increase and problems created by such mobility may become more widespread. The writer quastions whether problems bern by this mobility may be outstanding as compared with children who stay in one area throughout their six years in the elementary school?

Phillips2 also states that as education opportunities become more and more equal in different sections of the state and country as a wole, the problens resulting from educational deficiencies should become less important in dealing with the migrant pupil.

In Changing Times ${ }^{3}$ we find the statement, Most children go through the ordeal of a change of schools at least once bafore they reach the ninth grade."

As before stated, Americans are on the move as never before. The change may mean a move from a city to a suburb, a cold climate to a warm elinate, a small town to a metropolls, a house to an apartment, a modest neighborhood to a lancy residential neighborhood, or Irom outside the country to the United States or vice versa. These changes, regardless of where or what they are, are necessary to the family and on the whole may have a vast bearing on the total

1Beeman M. Phillips, "Impact of Pupil Mobility on the Schools", Educational Administration and Supervision, Vol. 43, (Pebruary, 1957).

2 Inid.

3"Changing Schools Next Month", Changing Times-The Kiplinger Yagazine, (August, 1959), pp. 17-18. 
picture of the child's growth and emotional stability. School Lifel states that seren and a quarter million children of school age, one out of every five, wored to a different house during the year between Yarch 1955 and Karch 1956.

Hayes 2 mentions that the Census Bureau claims that forty million Americans move every year. Mobility at armed force bases is the rule rather than the exception.

Mobility is a problem for all schools to face. As Iano states, some $34,000,000$ of us will be moving to other quarters during the coming year. Some families will move just around the comer or dorn the street, some to the next covnty, others to bordering states, and still others across many states. Mearly six million children aged fire to thirteen will be inrolved in this migration.

This increase in mobility of population will continue to grow through technological advances, scientific discoveries and inventions, and changes in modes of living. In recent years, since World War II, our industrial society has become more highly organized and as transpertation facilities have increased, there has been a tremendous increase in the number of fanilies moving from one place to another.

Bechmellerl states that there are two major reasons why families move. They are as follows: (I) The father seeks a better

Ischool Life, (June, 1957), p. 4.

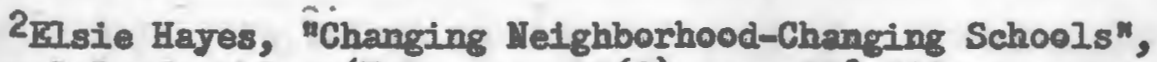
Rducational Leadership, (February, 1960), pp. 298-330.

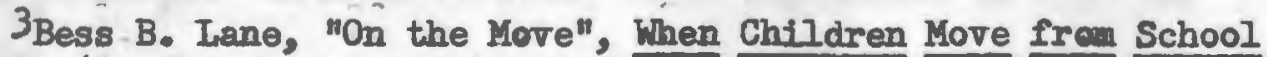
to School, (Assoctation for Childhood Education International, 1960), p. 3.

44. D. Buchmueller, "Foreword", When Children Move from

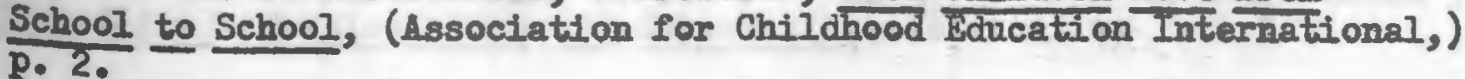


job with a higher salary, perhaps a larger home, a better neighborhood in which the children can grow up. It is a personal choice. (2) Increasing number of fanilies have moved because of some change in a parent's eccupation.

The fact that millians of children are annually uprooted frem known naighborhoods to the unknown, and from schools and communities faniliar to the child to those of unfamiliarity, challenges the home, school, and commanity to aid the child in his adjustment to these changes. Mobility will continue; each generation will become more adjusted to the change. Schools will be better prepared to meet these new children as they entar a new phase in thair school and community life.

III. Problems

Papil mobility, as mentioned by Phillips, 1 cites two problems for the schools.

1. Gotting pertinent information concerning the pupil's past parformances.

2. Problens of helping the pupil to adjust to his new school enviroment.

One of the outstanding problems with transient children is the lack of records. This problem limits the knowledge of placing the child in his proper grouping. Oftentimes this results in a hit and miss procedure. Tine elapses, the child has been enrolled for perhaps a week or more before pertinent information from his previous sehool is obtained. Without records, it is impossible to know why little Susan in third grade is still saying "tat" for cat. Was there

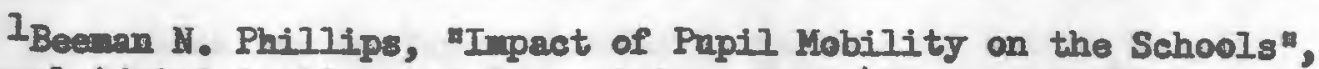
Bucational Adninistration and Supervision, Vol. 43, pp. 101-107. 
a seech therapist in the school from which she transforred? Had she had any speech training? Is this defective phonation her way of making herself known to the group? This is only an example, but it is such an occurrence as this that distrubs the new teacher. Susan nay have a hearing defect but no health record was available to inform the teacher. Records are important and a timesaver when a spectfic child is handicapped in some way.

With 25 per cent of our population on the move as stated by Martin, I it would appear that more schools should become accustomed to and have a knowledge of a transient popalation. If this were so, then imediate transfer of records may possibly take place. Information received from superintendent's questionnaires ${ }^{2}$ shows that records are transferred imediately when the transfer occurs within the state but only sent on request from outside the state. Otbers send a photostatic copy of records, the originals remaining with them. Many schools send, along with the transfer card, a card to be returned by the new school requesting other infornation and also giving proof the child has entered school. This is by far an easier and more rapid way of acquiring information than waiting for a letter of request to be sent from the new school. Oftentimes not even a transfer is arailable: then it is difficult to obtain the correct name of the school the child had attended.

In one of the North Kingstorm schools, a child entered the second grade without any records from the previous school. The child

IFrancis Martin, Mobility", Childhood Education, Vol. 34, (September, 1958), p. 25.

${ }^{2}$ questionnaires to Superintendents, results in fourth chapter and questionnaires in Appendix II. 
had difficulty from the beginning. It wasn't until four weeks later that the parent brought a report card to the school and informed us of a hearing difficulty the child had. The child was small for his age, younger than most of the children in the room, and his scholastic aduievement in the first grade did not warrant a pronotion although the ahild had been promoted. With these facts available and finally a transcript from his previous school, the child was then placed in the proper grade and grouping. However, fire to six weeks had elapsed before proper records were available. How much valuable school time is boing lost by lack of information?

Records also affect pupil accounting. Wahlquistl writes, Mnarican administrators have believed for many years that the census of the school population should be kept continuously np-to-date."

\section{Vhlquist ${ }^{2}$ continues explaining thus:}

A aimple annual census of school pupils is inadequate because of the migratory habits of the American adult population and the desire for freedom from governmental restraints. As no central registry of citizens is required, the school is forced to ascertain the ages of young people who should be in school. Some parents prefer to use the services of their children to supplement the family inceme, and others are merely negligent in conforming to school attendance regulations. The complex circumstances associated with keeping an accurate, and up-to-date schoel census in this dynamic society make it one of the major problems in school adninistration. However, the situation is far less acute in the twentileth century. than formerly.

The North Kingstown Schools are confronted at all times with this moving population. Entrances into the schools and transfers to

lJohn T. Wahlquist and others, "Pupil Accounting", The Anduistration of Public Education, (New York: The Ronald Pross), Pe 173.

${ }^{2}$ Ibid. 
-ther schools are comon occurrences. As seen in Potter'sl statistical tables, the enrellment of the elementary schools in North Kingstown for the year 1958-1959, was 2,177. The average nembership was $1,764,76$, making a difference of 413.24 between the enrollment and the average membarship, or a 23.36 per cent turnover during the year. This proves that North Kingstom is definately a mobile area; comparisons between mobile and transient children might well prove invaluable. The teachers and administrators are vitally concerned with this transient school population. Do these transient children compare favorably with the stationary child, or has the continual uprooting of the child had some adverse effect on his characteristics and scholastic achievement?

Records are not necessary for a child to become part of the comunity. This participation in commoity activities is of vitel Inportance to the transient child. He becomes one of another group outside of school, meets more people, and tends to feel a part of the whole social life of the torm.

Kyte 2 states that transients tend to have little commanity interest, fail to becone an integral part of the larger group and may even be detrimental to it. From this study, the writer determines to discover whether or not this statenent is true. Do these Navy children have any community interest or are they completely set apart from the commonity?

As pupil mobility increases, probleans created by such mobility may become more widespread. Educational opportunities may becone more

Iruth E. Potter, "Table VI", Statistical Tables, (Rhode Island: Dept. of Education, 1958-59).

p. 40 .

2 George C. KJte, The Principal at Work, (Boston: Ginn \& Co.), 
and more equal in different sections of the cowntry resulting in fewer problems from educational deficiencies in dealing with mobile propils.

IV. Adrantages and Disadrantages

Viewing the literature read and opinions from several aperintendents concerning transient children and problens confronted by school systems, the question arises as to the advantages or disadvantrges of transiency.

The literature reviewed contained mostly opinions on the reactions of children changing schools. Hayesl made a complete study of ways of aiding the transient child in his adjustment to a new situation. Iarson's 2 study pertained to the possibility of repeating a grade if many changes were made. Lano ${ }^{3}$ interviewed children inforwally to obtain their opinions about changing schools. Blough 4 wrote concerning the resources of children. Most of the literature read was epinion rather than studies.

\section{Disadvantages}

Disadvantages resulting from children moving from one school to another presents a problen for the parent, the child, the commanity, and the school. The writer, in conversing with parents, discovered that many parents tend to disregard the disadvantages a child may encounter in moving during the school year; many families

\footnotetext{
Ithages, 10e. cit.

2íarsen, loc. cit.

3tane, loc. eit.

4Glenn O. Blough \& Nlan I. Dodd, "Children Are Their Own Resources", Childhood Edheration, Vol 34, (September, 1958), p. 24.
} 
continue to do so, even noving and enrolling a child in a new school in June. The companionship of the family is vital to the child's groith. Parents feel that regardless of dismupting the child's school and community enviroment, it is mach better to keep the fanily together. Havy children are with their father for comparatively short periods; these periods are only accouplished by the moving of families from one area to another.

Ghildren moving from one school to another during the school year or sumer vacations may come in contact with many disadvantages. These should be weighed and examined to determine whether the disadinntages heavily outweigh the advantages or vice versa.

The likelihood of failing a grade is a good possibility for the mobile pupil. In Larsen'gl study, he discovered that children changing sehools are four times as likely to fail a grade as those who stay in one school.

Lany varied opinions regarding the disadvantages of mobility for the school age child are mentioned in the educational literature. A sumation of these disadvantages taken from Iarsen, 2 Ahrens, 3 Puilips, 4 Ivte, 5 Martin, 6 and Buchmueller7 follow:

1. Hore likely to fail than the stationary children.

2. Difficulty of adjusting to a new situation.

IDr. Robert E. Larsen, New York Times, Section IV-EII, (Eoptember 25, 1955).

Iold.

3ilavice R. Ahrens, Educational Leadership, Vol. 16, (Hovember, 1958), pp. $75-89$.

4phillips, loc. cit.

5irte, loe cit.

Gilartin, loc. cit. 7Buchmeller, loc. eit. 
3. The repetition and/or amission of subjects.

4. Leaving friends in the old school and the expectancy of what araits in the new.

5. Loss of curiosity in an attent to find security.

6. Does not dare to put down roote-he lites on the surface.

7. Reading difficulties from intarruption of the continuity of the reading progran.

8. Sometimes mat learn in a few months what others have learned in several years.

9. Work is disconnected and fragnentary.

10. Difficulty of obtaining records from previous schools.

11. Inability of some schools to cope with the child's problem due to the inarailability of records.

12. Iacking a feeling of adequacy and worth.

13. Bocoming adjusted and accustomed to new surroundings, friends, and teachers.

I4. Leaking interest in a community.

15. Arriving in high school without sufficient reading ability to carry on the work at this level.

16. Interruptions in the testing progran in order to diagnose and correct errors in school work.

Ortentines, parents must at a moment's notice pack their belongings and move to a new area. Some parents consider the children and renain in a particular town throughout the school year. Bren if the break comes during the school year and is most upsetting to the parents, "Changing rimes"l suggests that the parents avoid making their own werries known. School officials say that some of their mest unreasonable critics are the parents of children who transfer often. They have a tendency to blame the schools for troubles cansed by thair frequent noves. Youth", (Ghanging Tines-The Kiplinger Magazine, "Changing Schools Hext 
If disadvantages are to be minimized, actions by parents may be of value. I distinct wnderstanding between the child and the parent is of axtreme importance. The child should know all about the move and anticipate with the parents all the advantages of the more.

Parents, by their acceptence of a school system, can be of more belp than they realize. If parents accept the new system, as a rule, the children will do likewise.

Ianel interviewed parents, teachers, and children concerning their inpressions of changing schools. Few children expressed apathy or indifference; a few expressed pleasure or satisfaction in moving. The majority of children approached revealed concerns, worries, fears, or resentments. Some of the comnents made by the children are typical and tell their own story:

I worry about my work. I'm afraid I can't do it.

I'm scared. If only it weren't for arithmetic!

I know I'll be left back.

I don't. know what she will want me to do.

I don't want everyone eyeing me when I go in.

I don't know where the toilet is and probably the boys won't tell me.

I wish w father had to go to school and then maybe we worldn't have to move.

Laybe no one vill like me. I'm not very pretty.

Haybe the kdds will bump me off at recess.

When I was new in un last school, I thought the walls were coming in on me.

Comments from children may lead the way to the discovery of means in which we may help these transient children to adjust more rapidly to their new school.

Iane ${ }^{2}$ reports that teachers feel that the changing of schools is serious and has in the past been neglected by both homes and

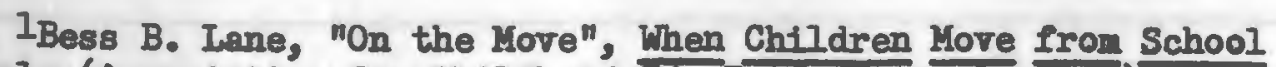
to School, (Association. for Childhood Ed. International, 1960$), \frac{1}{\text { p. } 3 .}$ 2Ibid. p. 4. 
sobools. The teachers montion the difficulties under which they work in ovarcrowded classrooms and the impossibility of giving needed help to newcomers.

One of the first concerns of teachers was the difficulty of getting reports from the last school attended. This is so often true, for in the North Kingstown school system sometires the child has moved again before reports from the previous school have been recelved. Not knowing, sometimes, exactly where the child is to attend school, the reports lie in the files until requested by the new school.

Each school is different; even in the same torm, changing from one school to another brings problens of rarying degrees. Is one man, new to toaching, sald, "It's as though Chevrolet started a car, two years later Ford added a bit to it, and some time later it was passed along to Rolle-Royce to get it ready for the long pull." This sums up quite clearly the variety of learning experiences by our transient children.

\section{Advantages of Mobility}

Advantages of mobility were mentioned slightly in the publications and books about the effects transiency has on a child. Bloughl writes that experiences in service provide a rich resource for school children. Children become a source of important inforration.

Many children, whose fathers are in the service, have received from them dolls from numerous countries of the world. These dolls often are brought to school when a specific country is

IGienn 0. Blough \& Mlan L. Dodd "Childran Are Their Oum Resources", Childhood Education, Vol. 34, (September, 1958), p. 24. 
being studied. They are shared with the children in the room and used as displays. This not only strengthens the transient child's stending in the group, but is a source of closer contact with the corntry being studied for the other children in the school.

Bloughl also mentions that the learning acquired by the children who travel widely in this country and abroad is assumed to be an aspect of importance.

The social studies program comes to ilfe in a room where there are many of these mobile children. They come from various states in the United States, have traveled through or Iired in them, and also other countries of the world. The interest shown by the children builds up like steam, each child contributing and receiring information from each other. Often parents vioit the schools with displays, novies or slides of states, peoples, and countries of the world. This brings to mind a child in one of the fifth grades in North Kingstown whose aunt had visited Buckingham Palace. In this fifth grade a piece of ivy was growing. This special piece of ivy had come directly from Buckingham Palace. How fortunate these children ware to have in their room something alive which came from a country many miles away. This is only one instance; there are others, for children from llavy families are rich in resources.

Yartin' ${ }^{2}$ states that it is important for schools to use the experiences of these children. If this is done, the child feels useful and respected.

\section{IIbid.}

2irancis Martin, "Lobility", Childhood Education, Vol. 34, (Septerber, 1958), pp. 25-28. 


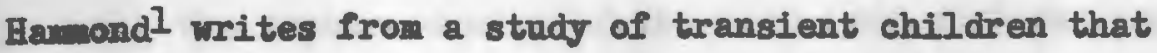
parontal opinion proved that the mobile child adapts very quickly, gets started imediately on class prejects, joins clubs and goes out for the athletic teams. They have very nice classroom manners, and seem to have a highly developed sense of social awareness. Parents agreed that their children made friends quickly, and usually ovaluate other children without undue reliance for consideration of background, raligion, or social status. The parents felt that advantages in Interrupted schooling outwrighed the disadvantages.

Whalquist ${ }^{2}$ states that mobile children learn to be alert, adaptable, rescurceful, and democratic. Iccording to Inne,3 nearly six million children aged five to thirteen will be involved in moving to other quarters during the coming year. These transient children are a challenge to the teachers in Imerica. The teachers will face a group of pupils who have lived in Burope, the Orient, other places in the Vorld, and all over the United States. The teachers will have the mique opportunity of aiding these pupils in their adjustment to a new situation, to determine their scholastic achievement, abilities and potentials, and make every offort to secure from them the best results possible.

VII. What others are doing

Teachers and parents can help secure the most from these

Irances Proctor Hamenond, A Study of the Achievement and Idjustment Patterns of Service-Connected children, p. 57.

2Wahlquist, Arnold, Canpbell, Reller, Sands, "Pupil Accounting", The Aduinistration of Public Education, p. 348 .

3Bess B. Lane, "On the Move", When Children Move from School to School, p. 3 . 
pupils by using the resources many of the transient children possess. [ares' writes concerning Fort Campell, Kentucley, A Strategic Irwy Cemand. It is comparable with most military areas. She states:

1. Hobility of the Fort Campbell population is the rule rather than the exception.

2. The tour of duty is two to three years.

3. A veritable strean of students flows through the schools.

4. Daily registration or withdrawal is routine.

5. Standardization does not extst in the schools.

Hajes $^{2}$ in the same article, presents several helpful procedures used by the Fort Campbell Schools.

1. Lobility makes mandatory a continuing evaluation of a systen of reporting pupil progress.

2. Continuing interpretation of school policies and procedures to parents.

3. Pupils are placed in groups that will encourage them to learn and will accelerate the adjustwent which each must make when he arrives at a new school.

4. Ieed for facilitating pupil-teacher adjustment.

5. Kaling it poseible to have the appropriate instructional materials in the hands of teachers and students at the right time.

6. Problem in predicting enrollments and providing adequate naterials.

7. Continuity of learning experiences toward educational objectives.

North Kingstown, being confronted with the same situation as Fort Campell, is using many of the procedures mentioned in Hayes'

IFlsie Hayes, "Changing Neighborhood-Changing Schools", Educational Leadership, (February, 1960), pp. 298-301.

2Ibid. 
article. Parent-teacher conferences are held regularly. Parents are ancouraged to visit the schools. When parents register their children, some of the schools present the parents with a school handbook and a P. T. A. Program for the year.

The P. T. A. publishes a monthly paper which is distributed to all the children.

If policies change or special events are at hand in the schools, bulletins are sent home.

Teachers are acclimated to receiving new pupils and each teacher has her own apecial way of introducing the new child and making him feel at home in his new surroundings.

Orientation programs for new teachers are conducted for three days prior to the opening of school. Many of the teachers, being the wives of naval parsonnel, have a real understanding of these transient children. Some have children themselves and so have had first hand experiences with the mobile child.

Instructional materials are alrars on hand making it possible for the new child to have available to hin at once all the materials being used by the other children.

Pupils entering with some clear record of past performances are placed in a group at his level of reading. Oftentimes teachers send with the pupil the title of the book and page in which the child was reading. This is a tremendous help in placing the student in a group conparable to the one in which he has been reading.

Undoubtedly one of the most difficult tasks is determining anrollments in September. Registration day is held a week before the opening of school. It is not until after this day that the 
number of different grades may be judged. A large turnover may take place from June.

The Providence Sunday Journal states that Superintendent Hiram 1. Davis mentioned that the vagaries of a constantly fluctuating school population - a large proportion of it from Navy families - have him stumped when it comes to predicting future trends. The elementary school enrollment rose only 1.3 per cent from 1958 to 1959 but soared on the opening day of school in September, 1960, to more than 10 per cent.

The Horth Kingstorm school system strives to do the best possible for these transient children. With registration day a week before school opens, the new child has an opportunity to view the school and plagground becoming slightly faniliar with his new environmant.

In Changing Times ${ }^{2}$ we find several ways parents may ald in the adjustment of the child to his new school. It suggests the following:

1. Let hin know early of the move, why it 18 necessary, and let him holp plan it.

2. Give hin a chance to visit the new school, meet the principal, teacher, and future classates.

3. Aroid making own worries known. "School officials say that some of their most unreasonable critics are the parents of children who transfer often. They have a tendency to blame the schools for troubles caused by their frequent moves."

4. See that the old school is prepared to send all necessary records to the new school.

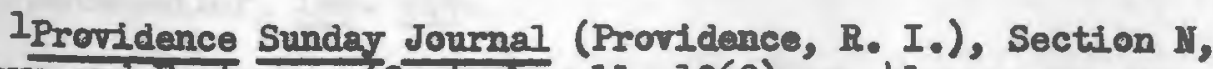
State New and reatures, (september 11, 1960), p. 41.

2"Charging Schools Next Month?", Changing Times-The Kiplinger Lagazine, (August, 1959), pp. 17-18. . 
5. Canfer with the youngster's current teachers and principal about his work and problens so you can discuss it with the new.

Hany parents are most co-operative in the above statements. They roalize the difficulties involved in changing schools and are willing to do 211 they can to assist. The majority let the school know ahead of time so records may be made ready. The one difficulty involved is not bowing exactly what new school the child may attend. This leaves some lapse of time before the new school can send for records which are not forwarded with the child. It sometimes occurs that before the records can reach the new school, the child has already transferred to another school.

Kiplinger Magazine, 1 Hayes, 2 Buchmeller, 3 Coldstain, 4 Ahrens, 5 Vartin, 6 and Lane 7 eite ways to enable the transient child to adjust antionally and scholastically. In most instances, the writers agreed on the following:

1. Classes of reasonable size to enable the classroom teacher to study individual children and their potentials.

2. Cumlative records transferred immediately to new school.

3. Parent-teacher conferences.

4. Heet needs of teachers - pernit creative and unvarul requests, for it is through these that creative and unusual needs are met.

5. Lttempt to make the child welcome in school. Goldstein 8 explains a sponsor system for new pupils. The sponsor is a friend of the new child and others help. The new child is

lKiplinger Magazine, loc. cit. 2 Hayes, loc. cit.

3Buchmeller, 10c. cit.

LGertrude Goldstein \& Paul Graubard, "Integrating the New Child", Childhood Education, Vol. 35, (November, 1958), pp. 111-113. 5Abrens, 10c. cit.

TLane, loc. cit. Grartin, loc. cit. 8oldatein, loc. oit. 
seated near the sponsor. This technique insured the integration of the new child rapidly and well.

6. Work in groups and individually.

7. After school visits.

8. Special classes, remedial instruction, counseling, and other means to facilitate the adjustment of the new pupil.

9. Provide needed learning experiences including testing, diagnosis, stress on specific neods, and subsequent reappraisal.

10. The help of agencies and community organizations.

11. If at all possible, let the child know about and view the school before his entry.

12. Home visits by the teacher and school visits by the parents.

13. Handbook of school policies and suggestions presented to the parents.

14. P. T. 1. bulletins and programs.

15. Bulletins from school.

16. Use in the classroom of avatlable material the child may possess, such as dolls, articles from other countries and states, mories, pictures, and slides from former places in which the child has resided.

17. Pre-school and post-school conferences for teachers.

18. Ffforts of curriculum steering to facilitate continuity.

19. Helping the child to read maps so that he may plan the route to his next destination.

As a rale, these mobile children travel a great deal more than their teacher. It is impertant to know when a child may be taken from one enviroment to another successfully. Kartinl

describes how the nursery man knows when to move a tree. He reglizes when the tree is small it developes balls of roots. These roots must

Irancis Martin, Mobility", Childhood Education, Vol. 34, (Septramber, 1958), pp. 25-28. 
be protected. The nursery man knows how to strengthen and protect these roots after each move. Martinl suggests that we study the same problem for our children in this mobile age. For a change of bed, the child might visit the neighbors, his grandparents and/or go on a camping trip. The child mast learn how to leave old friends. He writes letters and needs help in keeping up old friendships until the sadness and shock of parting has been eased.

The letter uriting often occurs in the North Kingstown Schools. Teachers are delighted to hear from all the children who transfer; teachers are especially interested to hear from a child who had been a problem. They are interested in how his adjustment is taking place. It brings to mind a boy who had been in our system for a year and a half. During practically all of his first year he was a continual trouble-maker. Gradually he found his place in the school and was liked by his classmates and teachers. Then the move came. The question was, "How will Kichael adjust to his new situation?" From being such a trouble-maker, it was anazing to note that all the children in his room cried when he was leaving. Hot long after arriving at his new school, Hichael wrote to his teacher and classmates. He axplatned many policies of the school, some of which differed from ours, described the school, teacher, and some of his classmates. Bridently, from the content of these letters, Michael had made the proper adjustment to a new situation. He continued to write but the space of time between letters gradually grew longer. We see in this respect how letter writing enabled 
Wf chrel to keep in contact with his old friends while making friends with his new classmates.

VIII. Summary

Educators are concerned about the mobile child. It may be that too moch exphasis is being placed on his adjustment. He, the nobile elatld, may be learning better than the stationary child the way of life which people will lire in the future. Children are living in a rapidly changing culture. Iransiency is growing but this could possibly be the true way of introducing our youngaters to a ahrinking world. Hobility may be a way of helping a child to recognize his life problems whether in home or school and furnishing him with techniques for attacking them intelligently. As we relieve a child, whether transient or stationary, from fear of failure or fear that his nolghbor will be better than he, the child can give his full attention to using all his resources to further his own progress. In June, in North Kingstown, the children transferring from a school they had attended for flve years were taken for an orientation program to another school in town which takes care of practically all the fifth and sixth grades. When the stationary children rotumed, dissatisfaction of their new school reigned supreme among then. Little was said by the mobile school population. These atationary children were being uprooted for the first time. They ware to attend a school in the same town, but having attended a school for five years and being acquainted with all 1ts aspects, Insecurity was outstanding in this stationary group.

As children continually move from school to school; from one tom to another, and/or from state to state, they are learning 
to live in a world with a rapidly changing culture. Whether this is to their advantage or atherwise is still a matter of much conjecture. It is hoped that this study of mobile and stationary children of Horth Kingstown will help to determine whether mobility has affected seholastic standing and adjustment as compared with a stable school population. 
CHAPTER III

\section{METHODS AND PROCEDURES}

\section{Introduction}

This research wes designed to investigate whether or not any aignificant differences exist between the transient and permanent children in an inpact area such as North Kingstorm. The academic achievenent as well as general characteristics were intensely studied. Since an extensive review of the literature partaining to this area revealed a fer factual studies, it was felt that a study such as this might well make a real contribution to knowledge in this fleld. To this end data was gathered on the approxinately 450 children in the town of North Kingsterm, Rhode Island. In addition, superintendents of schools in fifty inpact areas throughout the United States were queried for their views on the problems created by the continual flow of children through their school systems.

\section{Design}

1. Twelve letterglwere sent by the initer to superintendents of schools in impact areas similar to North Kingstown. These were sent prior to undertsking the main investigation for this thesis in order to obtain opinions concerning problems relating to 
transient children from superintendents who were confronted with a ditlar mobile population as North Kingstown.

Since one superintendent mentioned that he could be more apectfic if a questionnaire were sent, a four page questiomairel was propared and sent to fifty superintendents in inpact areas throughout the United States. I space was reserved beside each quastion for renarks from the superintendents. It was hoped that thits opportunity for free response might provide data of a more extansive nature.

The questions pertained to records and the ease in which they were forwarded when the pupils transfarred to new schools. Questions also referred to special classes, comnseling, conferences, remedial reading, groupings, speech therapy, foreign languages, and ifpressions of the acadentc achievements of the transient students.

Thirty-seran, or serenty-four per cent of these questionnaires were returned. The results will be sumarized and discussed in the following chapter.

B. Academic Achievement. The Iowa Tests of Basic Skills were achinistered to the children in Maj, 1960, to determine how well all the children had mastered the basic sicills. I comparison of the scores between the transient and permanent children should comonstrate the differences, if any, in the mastery of the basic akdis.

The I. T. B. 5.2 is a reputable group of tests 3 which assess

ISee Appendix II.

2I. T. B. S., Iowa Tests of Basic Skills.

30icar K. Buros, Ed., Fifth Mental Measurement Yearbook, (Island Park, New Jersey: Gryphon Press, 1959), pp. 30-37. 
strength and weakness in the following fundamental areas: (1) vocabulary, (2) reading, (3) mechanics of writing, (4) methods of study, (5) arithmetic.

Not only are these tests nationally known, but the writer felt that the children should be given a test which they had never had previously. In February, all children in the North Kingstown Henentary Schools were administered the Metropolitan Achievement Tests. Some of the transient children may have been fanilitar with the I. T. B. S., but it is doubtful that they had had it in the spring of 1960.

The I. T. B. S. are divided into five areas as follows:

i. Vocabulary

2. Reading Comprehension

3. Language Skills
4. Work Study Skills

5. Arithmetic

The teacher's Manuall describes each test in the following

manner:

1. Vocabulary: To determine the skill gatned in the use of tools involved, such as phonics, context, etc., and the understanding of the meaning of words.

2. Reading Comprehension: To test the chilld's abilitty in the following items:

a. To recogaize and understand stated or implied factual details and relationships.

b. To develop skill in discerning the purpose or main idea of a paragraph or selection.

c. To develop the ability to organize ideas.

d. To develop the skill in eveluating what is read.

3. Language Skills: These skills will show the abilities of the child in spelling, capitalization, punctuation, and usage.

l Teacher's Manual, Iowa Tests of Basic Skills, (Boston:

Doughton ifflin Co., 1955 \& 1956), pp. 23-40. 
4. Work Study Skills: These skills measure the child's ability in map reading, reading graphs and tables, and knorledge and use of reference material.

5. Arithmetic: To determine concepts involving knowledge of the number, systen, whole numbers, fractions, decimals, per cents, standard measures, geometric figares, ratio, and propertion. The arithmetic problem solving is set up to determine the ability of the child's understanding of the arithnatic processes.

These tests were administered by the principels in each school or the classroom teacher who had had previous experience in adinistering tests. The principal of one school corrected all the tests in that school. Some of the other tests were corrected by the tenchers, but the majority of correcting was done by the writer.

The scores on the test were tabulated according to assigned grade level for the categories here under consideration. Following the tabrlation, a statistical analysis of the tests was performed by testing the differences for significance through the critical ratio test of the mean differences.

C. Writing samples were obtained by each child writing a ceposition antitled, "What Changing Schools Means to Me." If the pormanent child did not care to write about this topic, he wrote concerning, "Thoughts About June". This devlce was used primarily to obtain a ample of the child's handwriting. The child's thoughts, opintons, and impressions relating to changing schools will be included in the folloring chapter.

The quality of penmanship was determined for each child from these compositions. Methods of teaching writing vary in the schools. Some children begin with cursive writing, others with manuscript. By the time a child reaches fourth grade, he has usually learned the cursive style. However, since each child's handwriting varles, no 
upectfic atyle was considered to be the best when grading the penmanship papers. The papers were marked for permanship by the writer utilizing numerals as follows:

$$
\begin{array}{ll}
1 \text { - Excellent } & 3 \text { - Fair } \\
2 \text { - Good } & 4 \text { - Poor }
\end{array}
$$

Saples of the handwriting from each grade in the categorles, $1,2,3$, and 4 listed above will be found in the Appendix III. The handwriting scores were analysed statistically by use of the chisquare technique.

D. Characteristics were studied through use of a teacher eraluation form on a four point scele.1 The characteristics included in the form were resourcefulness, alertness, adaptability, verbal cxpression, creativeness, enthusiast, work habits, popularity, care of school property, attitude, punctuality, honesty, afficiency, lhyness, being a show off, agressiveness, persistency, and distractibility.

Much of the literature read by the author contained expressions of concern regarding the adaptability of the transient child. Hence, the author felt a comparison of characteristics between the mobile and stationary children might demonstrate the existance, if any, of noticeable differences in the two groups of children.

Only the teacher's impression of the characteristics of the children was considered. Since this thesis concerned the child in the alassroom, the writer felt that the tercher's opinions would provide a basis for valid judgments. Each characteristic was marked with numerals. An explanation of the numerals follows: 


$$
\begin{array}{ll}
1 \text { - Brcellent } & 3 \text { - Fair } \\
2 \text { - Good } & 4 \text { - Poor }
\end{array}
$$

A few characteristics, namely, shyness, distractibleness, show offness, agressiveness, and persistentness were marked as follows:

$$
\begin{aligned}
& \text { Y - Yes } \\
& \text { N - No } \\
& \text { A - Average }
\end{aligned}
$$

All the characteristics were tabulated for the entire sample irrespectful of the grade level. These were then analyzed for statistical differences by the use of the chi-square technique.

B. Pertinent information pertaining to the ohflidren, such as broken homes, attending a number of schools, repetition of a grade, and entering community activities were discovered through another form 1 filled out by the teachers with some records being located in the uparintendent's office. The data collected relating to the incidence of broken homes, non-promotion and community activities among the two groups was analysed statistically by the use of the chi-square tochnique.

III. Population

of the six hundred or more children in grades four, five, and $s i x$ in North Kingstown, approximatel $y^{2} 460$ comprise the sample for this research. Approximately 150 did not meet the speeifications set for this study for either transient 3 or permanent 4 status.

\section{$I_{\text {See Appendix VI. }}$}

${ }^{2}$ Apprordmatelys This word is used because the number of children vary on the different tests. Some were absent, some left while the tests were being administered, and other tests were left mondone for reasons unknow to the writer. The forms, marked by the teachers, were not completely filled in; therefore, the number of children do not remain the same throughout the whole research.

${ }^{3}$ See Chapter I, p. 17. 
These children had been enrolled in the systen for more than one and one half years but had not entered in the first grade.

Transient children, numbering approximately 206, were children who had been enrolled for one year and a half or less by Kay, 1960. No child was considered if he entered in the system before December 1, 1958. These children were not classified as to intelligence and/or ability. The writer felt then to be an average group of children. Their parents' rank in the Navy ranged from Seaman to Captain. The seato-economic status of this group would doubtless range from lowerAlddle class to upper middle class. The range may even go higher or lower on the socio-economic scale. It was definitely not a selected group of children but a typical group to be found at almost any area where a lavy base is situated.

Table 1 gives a clearer picture of the transiency of these students. The number of different schools the children attended are listed. There is a noticeable difference in the number of children (221) as compared with the approximate number (206) used in this study. Before the tests were administered and during the testing children had transferred to another school.

\section{TABLE 1 - NOMBER OF DIFFERENT SCHOOIS} TRANSIENT CHIIDREA HAVE ATTEMDED

\section{Grade Four}

Wo. of Different Schools Number of Children

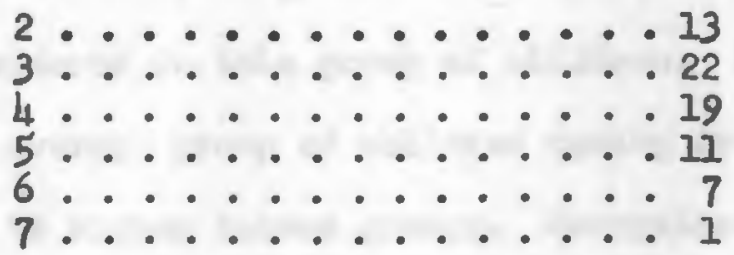


Grade Five

No. of Different Schools Number of Children

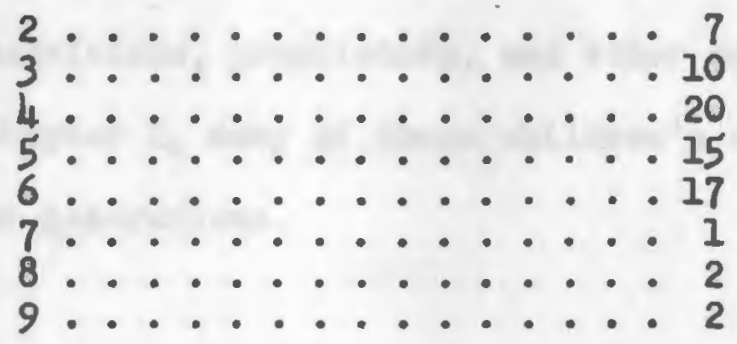

Grade Six

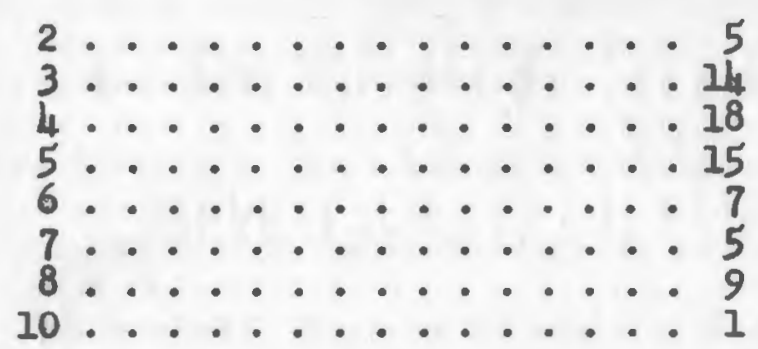

\section{Totals}

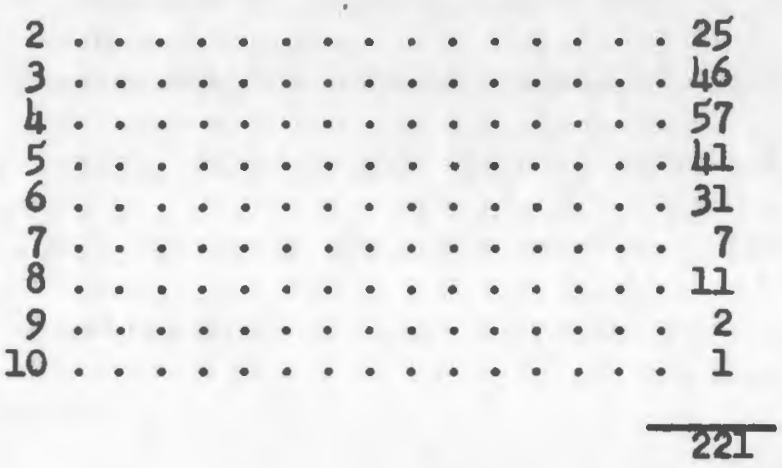

Permanent children, numbering approximately 243, were those who ontered first grade in North Kingstorm and continued throughout the fourth, fifth or sixth grade in the system. No intelligence range was considered in this group of children. They were considered to be a truly average group of children coming from families of lower income groups to higher income groups. Occupations of the parents 
of this permanent group included laborers, farmers, fisheren, business nen, teachers, carpenters, salesmen, supervisors, airplane mechanics, electricians, proprietors, and other occupations. As aplained in Chapter I, wany of these children's ancestors had lired in the area for generations. 
CHAPTER IV

\section{RESULTS}

\section{Letters from Superintendents}

of the twelve letters sent to superintendents in inpact areas, seven replies (58\%) were received. In these replies many aparintendents felt that these transient children prosented no extstanding problens waless below average in ability. If anv deficiencies were present, these were uswally in reading and arithmetic. These deficiencies were taken care of by remedial teachers or coordinators of reading, directors of special swbjects, and by small classes ranging between twenty to thirty pupils.

On the whole, there seemed to be a waninous feeling that the characteristics of these children were no different from the parmanent children and most of then adjusted very readily to a new school situation.

II. Questionnaires

Of the fifty questionnoires sent to superintendents, results, based upon the thirty-seven (74\%) returned, follows:

Question 1. Fleven superintendents (30\%) reported that a transcript was sent with the child when he transforred. Twenty-one (57\%) atated that the transcript was sent anly when requested by a sehool, and four (II\%) reported no transcripts were forwarded. One 
Wurintendent (2\%) did not answer. As a rule, most schools sent trengeripts by request.

Remarks included with question one are as follows:

Three superintendents reported that only a transfor and health cerd was sent with the child.

Some places sent photostatic copies, keeping the originals in their files.

One sehool sjsten reperted that the transcript is sent when it is known where the child is transferring to and does not wait for a request.

Gastion 2. The question of cumulative records vas sinilar to the transfers. In one system the cumlative records were kept in the papils' records office and a form issued for transcripts of gredes and other information. In North Carolina a cumelative Iolder aesompanies transferees within the state. In California the cumlative record transfer is antomatic within the state but only sent outside the state upon request.

Guestion 3. Irenty-four superintendents (65\%) reported sending achievement test records when requested by the principal. Irelve (32\%) reported these records were sent without a request. One (3\%) reported these results to be on the transcript sheet. Question 4. Intelligence quotients were sent by twenty-tre schools $(5 \%)$ then requested by the principal of the new school. One (3\%) experintendent reported that this information was not forwarded and twelve (32\%) reported sending it antomatically. One (3\%) mentioned it as being on the tranecript sheet. One superintendent (3\%) did not answer.

Question 5. Health records were sent along with the trangfers by twenty-two towns, $(60 \%)$ by request in thirteen (35\%), 
and not at all in two (5\%). As with other records, this is automatic in Cafifornia within the state and on request outside the state. One apporintendent reported that if the question was in regard to health, the information went through the Health Service Department.

Question 6. Lny specific difficulties about the child were sent by eighteen school systens (49\%) and by nineteen (51\%) when requested by the principals. One superintendent reported that if it were a mantal problem or one of serious illness, the signature of the parent or legal guardian must accompany the request. In two cases this information entered was on the permanent record or a photostatic copy was sent by request.

Question 7. Reading lists of the books read by the children were sent with the transferee by seventeen school systems (46\%). Ten (27\%) were sent by request and seven (19\%) did not send any. One mperintendent (3\%) mentioned they were beginning this year to send them and another (3\%) felt there was little value in forwarding this kind of information. One superintendent (2\%) did not answer.

Question 8. Confidential records were sent by twenty-five school systams (67\%) when requested by the principal of the new school. Two (5\%) systems sent this information with the child and Iive (I4\%) did not send any. One superintendent (3\%) stated that if the problem were mental, or a serious 117 ness, the sigmature of the parent or legal guardian must accompany the request. In another school system (3\%) coples were sent and one sxperintendent (3\%) stated that this nswally pertained to special class children. Two (5\%) did not answer the question.

Question 9. Conferences with the parents of new students were held by ten systems (27\%), if necessary. They were held by 
gine (24\%) always and by eighteen (49\%) sometimes. One superintendent mationed that a conference with the parent was mandatory within two weeks of the child's entrance into the school. Three superintendents stated that the principal always hes a conference with the parents. One aparintendent stated that an attenpt was made to see new parents when the child enrolled.

Question 10. Cwralative records or confidentiel records of students were sent imediately by thirty-two school systems (86\%), three (8\%) sometimes, and one (3\%) not at all. One superintendent (3\%) did not reply.

guestion 11. Counseling to facilitate the adjustment of new students is available in sixteen systems (43\%); nine (24\%) if necessary, and not available in eleven systens (30\%). One superintendent (3\%) Pelt that the elementary classroon teacher is the best counselor. In two sahools the prineipal, teacher, and/or visiting teacher aid the children in their adjustments. One systen had six frll-time guidance counselors.

Question 12. Parents were enceuraged to visit schools in thirty-two communities (86\%), four (17\%) if necessary and in one (3\%), somotimes. One superintendent stated that the parents were always meouraged to visit and parent-teacher conferences were expected. Both must be by appointment. Other superintendents mentioned that parents visited after students were disurissed or at specific times.

Guestion 13. Parents are requested to come with the children when thoy enter a new school in twenty-four systens (65\%). Seven (19\%) were requested to regiater the child if necessary, two (5\%) sometimes; two superintendents (5\%) stated that parents were not 
recrested to come with the children when they registered. One operintendent (3\%) stated that there was no specific rule and 211 parents seem to know enough to come with the pupils. One superintendent (3\%) did not reply.

Question 14. In regard to a handbook presented to parents at the time they register their children, there were various answers with only sixteen (43\%) actually presenting a handbook and seventeen (46\%) definitely not. Three superintendents (8\%) mentioned that some schools present a handbook and another (3\%) that individual schools derlse their own booklet or bulletin to meet this noed. One system sends out a handbook before the children are registered. Another has a handbook in the planning stage. One presents parents with a letter of greeting containing pertinent information.

Question 15. Twelve systems (32\%) reported having special elasses to take care of individual differences, if any, in the transient students. Twenty school systems (54\%) had no such classes. One suporintendent (3\%) reported the children making wonderful adjustments. In one system (3\%) the pupils were tested on the day they registered and then placed in groups according to their adhterement. Two (5\%) had special classes for the mentally retarded children and one (3\%) for those who were emotionally distrubed. Classes in renedial reading were held in some systems.

Question 16. Opinions concerning any outstanding differences botween the transient and permanent children were many and varied. Trelve superintendents (32\%) felt there were outstanding differences between the two groups. Nine (24\%) felt that no differences were gresent. Fifteen (4I\%) seemed to believe there was little difference. One mperintendent (3\%) did not answer. 
Results, entered beside the colvm "renarks", follow: (1) The transient children posses a wealth of information and knowlodge but lack technical slills, (2) There is a great deal of diffarence. The brightest are equal and above. The majority are below the stationary population. (3) Some contribute much to the class. (4) Some have emotional problems but so do the permanent children. (5) Service peoples' children tend to excel in social studies. It depends on the section of the country they come from. (7) Most of them are normal children. Some have been shorted on opportunities. (8) It dopends upon the area of the United States from which the children transforred. (9) We have fifty per cent Navg. They are typicel joungsters.

Qrestion 17. Thirteen school systens (35\%) reported renedial reading teachers. Fight systems (22\%) had none and ten (27\%) had remedial reading teachers in some schools. One school systen (3\%) had two full time reading coordinators who work with the teachers. In another school (3\%), grades four, five, and six had a reading teacher outside the core. One school superintendent (3\%) mentioned that the remedial reading classes were not a "catch-all" for poor students. Two superintendents (6\%) did not report.

Guestion 18. Pre-school conferences were held with new teachers to orient them to the situation of mobility in the classroom in thirty-one scheol systons (84\%). Two systems (5\%) had no pre-school conferences and four systens (Iis) held them sometimes. One ouparintendent reported that most of the staff are service connected and understood the problen. Another superintendent stated that a two week coupulsory workshop for all teachers is scheduled. 
question 19. In answer to the question of placing transient pupils in groups at or near their achievement level, sixteen school apprintendents (43\%) reported "yes", eleven (30\%) reported "no", and seven (19\%), "when pessible". Three superintendents $(8 \%)$ did not reply. The following remarks were made: (I) We have a modifled Joplin Plan for reading skills. (2) Grouping is at the discretion of each principal. (3) Within the class for specific purposes. (4) Within class itself.

Question 20. Speech therapy seemed to be outstanding in most school systems reporting. Twenty-seven systems (73\%) had apeech tharapists. Five systems $\left(i_{4} \%\right)$ had none and four (11\%) had speech tharapists in some schools. One superintendent ( $2 \%)$ mentioned that this service was very mach needed. Another had part-tine help, and one had a speech therapist on a limited basis.

Question 21. The size of the classes from the various merintendents follows:

$\begin{array}{lcc}\text { Class Size } & \text { No. Reporting } & \text { Percent } \\ \text { under } 20 & 1 & 3 \% \\ 20 \text { to } 25 & 1 & 3 \% \\ 20 \text { to } 30 & 20 & 54 \% \\ \text { above } 30 & 12 & 32 \% \\ 30 \text { to } 35 & 2 & 5 \%\end{array}$

One superintendent (3\%) reported thirty in grades one, two, and three - above in other grades.

Question 22. Opinions from superintendents about the question as to whether or not the mobile children would have progressed farther in reading had they had no interruptions in their learning are as Pollows:

$$
\text { Yes - } 20(54 \%) \text { No }-2(5 \%) \text { Doubtful - I4 (38\%) }
$$


One superintendent (3\%) did not reply.

Remarks are as follows: (I) Yes, if they were in a good system to begin. (2) Depends on the individual situation. (3) We find most children using the same text and materials as we do. (4) Depends upon the schools attended. (5) They lose a full jear after sereral moves. Many start too early. Most transfer students from some states are six months to a year behind in reading.

Question 23. The answers concerning progress in arithmetic were similar, with reports showing:

$$
\text { Yes }-18(4 \%) \text { No }-2(5 \%) \text { Doubtful - } 13(35 \%)
$$

One superintendent (3\%) reported that most slow readers were average in arithmetic. Three superintendents (8\%) did not reply. question 24. Superintendents in twenty-nine systems (78\%) felt that mobile children have rich experiences in history and geography. One superintendent (3\%) did not feel they had and seven (19\%) did not answer. Under remarks were the following: (1) Overall but not as much ahead as it would seem on specific subjects. (2) Many do. Not all. (3) It is possible. (4) Many do not capitalize on their experiences. (5) Mobile children have great advantages over our rural children and often are a big help in class. (6) Depends upon the degree of mobility. (7) Sometimes. It depands on the Thividual. (8) Depends on the type of fandly and the experiences indergone.

Question 25. Opinions concerning work study skills of mobile elilldren being on a level with the permanent children were:

$$
\text { Ies - } 18 \text { (49\%) No - } 11 \text { (30\%) No Answer - } 8 \text { (21\%) }
$$

Remarks were as follows: (I) It depends upon the background. 
In our case they are generally on the same level. (2) Interrupted iducation from varions vilitary locations seems to have its affect. (3) slightiy below. (4) Varies.

gmestion 26. Concern over the adjustment of children to a now aniroment seemed to have Iittle signifleance. Superintendents answared as follows:

$$
\text { Ies }-1(3 \%) \quad \text { No }-12(32 \%) \quad \text { Iittle }-17(46 \%)
$$

There was no reply from seven superintendents (19\%). Remarks fellow: (1) This depends on the parental attitude toward the new anvirenment. It is contageous with childran. (2) It depends on the ohild, fantly, school, and commeity. (3) Yot usmally. Brperience seems to have halped them. (4) Generally speaking, no. Individuals are bound to find change not to their liking. (5) It depends on the Individual.

Qrestion 27. Superintendents in sixteen systens (43\%) replied that a forelgn language was being taught, whereas fifteen aparintendents (415) reported it as not being taught. Six superintandents (16\%) did not reply. Remarks follow: (1) Spanish anly at present. We expect to expand. (2) Only in one school out of twoatydight. It is on an experimantal basis. (3) French - T. V. (4) Spanish - T. V. (5) Private classes in French. (6) In planning stage. (7) In nine out of sixty-one elenentary schools. We plan to discontinue 1t.

Question 28. The question arises as to what to de with the mobile child who enters a systen where a foreign language is being tuaght and the child has had no previous foreign languages. Thirteen cuporintendents (35\%) reported that these children enter the foreign 
language class. One reported (3\%) no, two (5\%), sometimes, and trenty-one (57\%) did not reply.

Remarks follow: (I) Yes, if they were taking Spanish elsewhere. (2) Some difficulty if the child had no previous background.

III. Iowa Tests of Basic Skills

111 of the T. T. B. S. were analyzed statistically through the use of a critical ratio test of the mean differences. No significant differences were found in any test at any of the grade levels. The only test which begins to approach a significant difference was the fourth grade test on map reading. Here the transient child seemed to be alightly superior. However, the critical ratio proved even this test to have no significant difference.

The means on each test reveal all children to be above grade level with the exception of the map reading and problem solving tests of the permanent children in grade four, and the map reading test of the transient children in grade five.

Table 2 gives the results of the tests for grade four, Table 3 for grade five, and Table 4 for grade six. In Appendix IV will be found graphs depicting the distributions for each test in the three grades.

Pallipsl stated that educational opportunities may become more and more equal in different sections of the country resulting in fewer problems from educational deficiencies in dealing with mobile pupils.

I Beeman N. Phillips, "Impact of Pupil Mobility of the Schools", Pheational Administration and Supervision, Vol. 43, (February, 1957), P. 101-107. 
TABLE 2

IOWA TESTS OF BASIC SKILIS POR GRADE FOUR

\begin{tabular}{|c|c|c|c|c|c|c|c|c|c|c|c|c|}
\hline $\begin{array}{l}\text { Iowa } \\
\text { Subtests }\end{array}$ & \multicolumn{2}{|c|}{ Vocabulary } & \multicolumn{2}{|c|}{$\begin{array}{l}\text { Reading Com- } \\
\text { prehension }\end{array}$} & \multicolumn{2}{|c|}{ Spelling } & \multicolumn{2}{|c|}{$\begin{array}{l}\text { Capital- } \\
\text { ization }\end{array}$} & \multicolumn{2}{|c|}{$\begin{array}{l}\text { Punctu- } \\
\text { ation }\end{array}$} & \multicolumn{2}{|c|}{ Usage } \\
\hline $\begin{array}{l}\text { Groups } \\
\text { Transient/Permanant }\end{array}$ & $\mathbf{T}$ & $\mathbf{P}$ & $\mathbf{T}$ & $\mathbf{P}$ & $T$ & $\mathbf{P}$ & $\mathbf{T}$ & $\mathbf{P}$ & $\mathbf{T}$ & $\mathbf{P}$ & $\mathbf{T}$ & P \\
\hline $\begin{array}{l}\mathrm{N} \cdot \cdot \cdot \cdot \cdot \cdot \cdot \cdot \\
\mathrm{R} \cdot \cdot \cdot \cdot \cdot \cdot \cdot \cdot \cdot \\
\mathrm{Mean} \cdot \cdot \cdot \cdot \cdot \cdot \cdot \\
\mathrm{SD} \cdot \cdot \cdot \cdot \cdot \cdot \cdot \cdot\end{array}$ & $\begin{array}{l}104 \\
2.7 \\
8.7 \\
5.08 \\
2.12\end{array}$ & $\begin{array}{l}100 \\
2.3- \\
8.7 \\
5.12 \\
2.16\end{array}$ & $\begin{array}{l}107 \\
2.3- \\
9.3 \\
5.28 \\
2.27\end{array}$ & $\begin{array}{l}96 \\
1.7 \\
8.7 \\
5.09 \\
2.21\end{array}$ & $\begin{array}{l}102 \\
2.7 \\
8.7 \\
5.43 \\
2.14\end{array}$ & $\begin{array}{l}99 \\
1.7- \\
9.3 \\
5.43 \\
2.40\end{array}$ & $\begin{array}{l}103 \\
2.7 \\
9.7 \\
5.53 \\
2.51\end{array}$ & $\begin{array}{l}100 \\
2.3- \\
9.3 \\
5.32 \\
2.36\end{array}$ & $\begin{array}{l}101 \\
3.3- \\
10.3 \\
5.67 \\
2.71\end{array}$ & $\begin{array}{l}102 \\
2.7- \\
9.3 \\
5.36 \\
2.33\end{array}$ & $\begin{array}{l}101 \\
2.3- \\
8.3 \\
5.15 \\
1.98\end{array}$ & $\begin{array}{l}103 \\
1.7 \\
8.7 \\
5.09 \\
2.15\end{array}$ \\
\hline $\begin{array}{l}\mathrm{GR} \cdot \cdot \cdot \cdot \cdot \cdot \cdot \\
\mathrm{P} \cdot \cdot \cdot \cdot \cdot \cdot \cdot \cdot\end{array}$ & .08 & S.* & & $\begin{array}{l}31 \\
\text { s. }\end{array}$ & $\begin{array}{l}.09 \\
\text { N. }\end{array}$ & & & & & & & 34 \\
\hline
\end{tabular}

Hot significant at the .10 level 
TABLE 2 - Continued

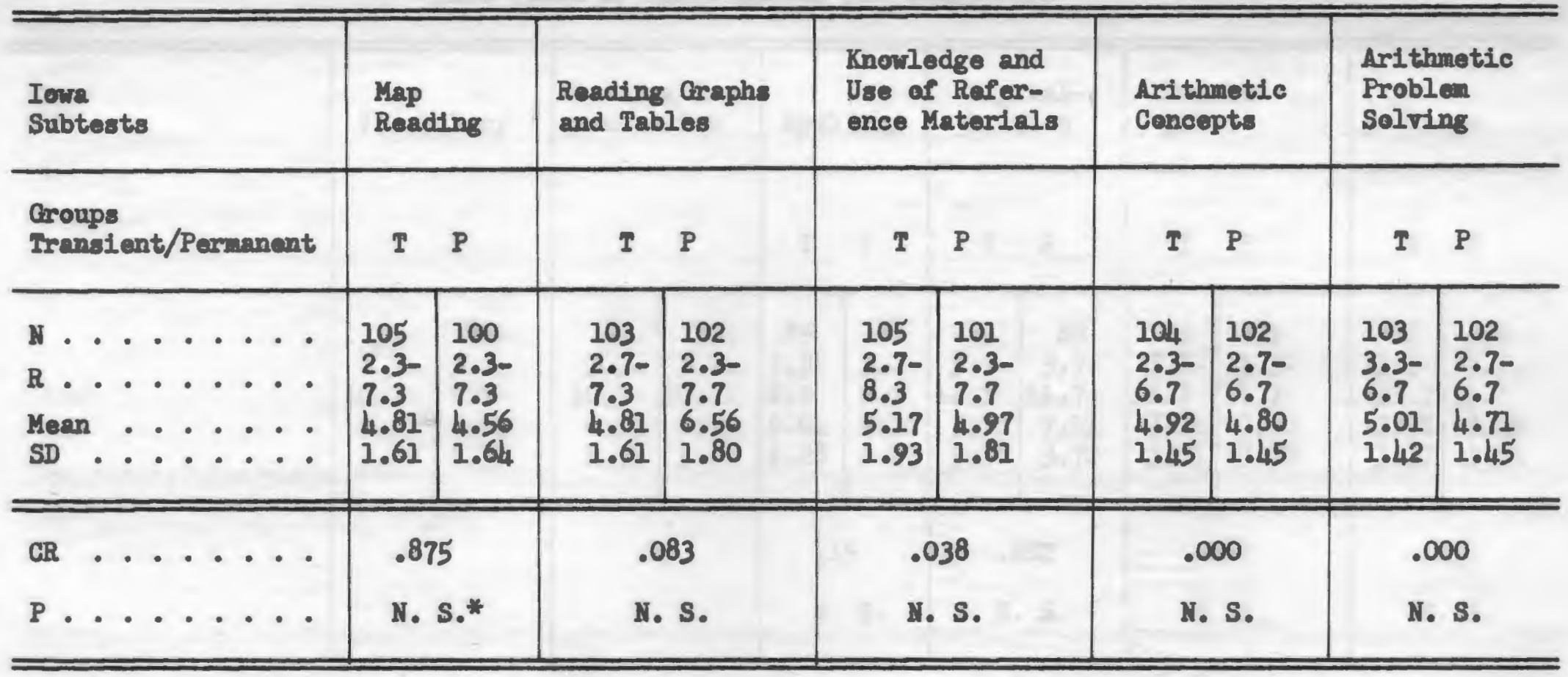

*iot signifleant at the .10 level 
TABLE 3

IOWA TESTS OF BASIC SKILLS FOR GRADE FIVE

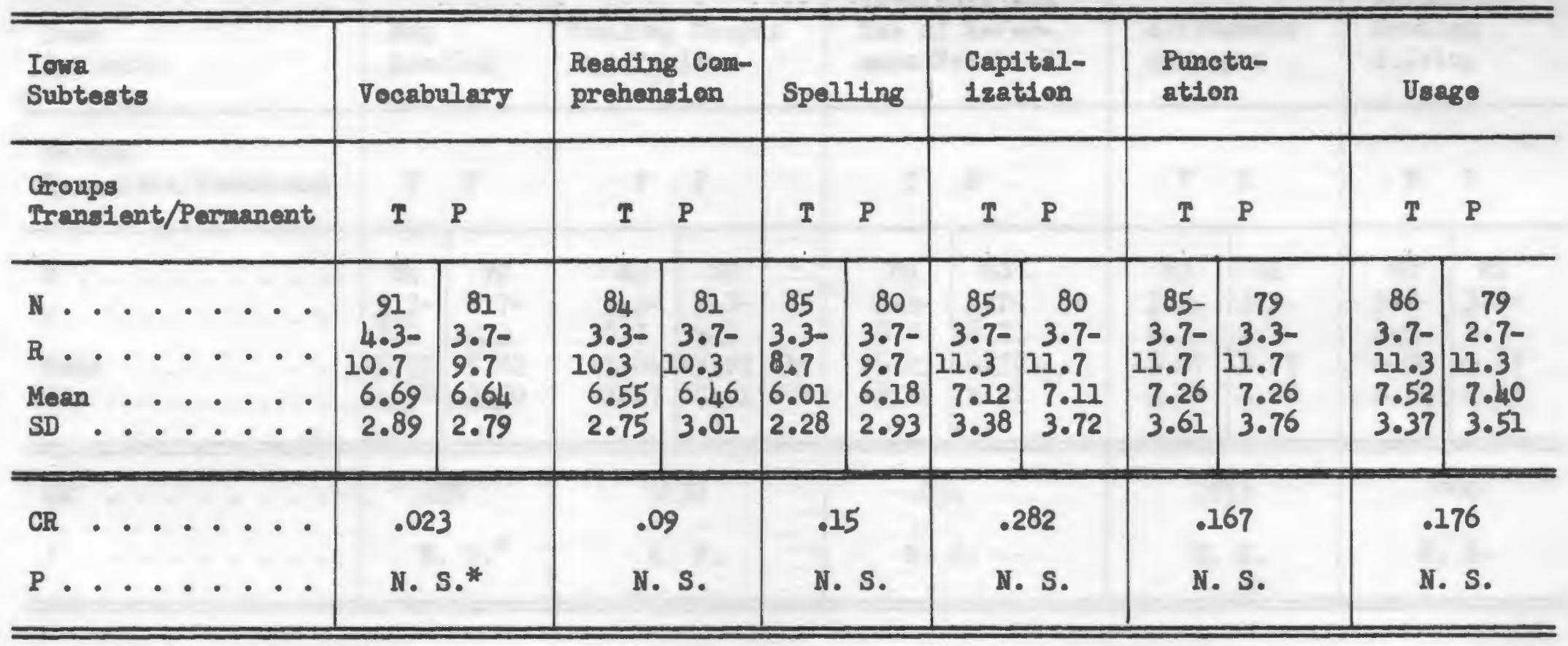

Not significant at the .10 level 
TABLE 3 - Continued

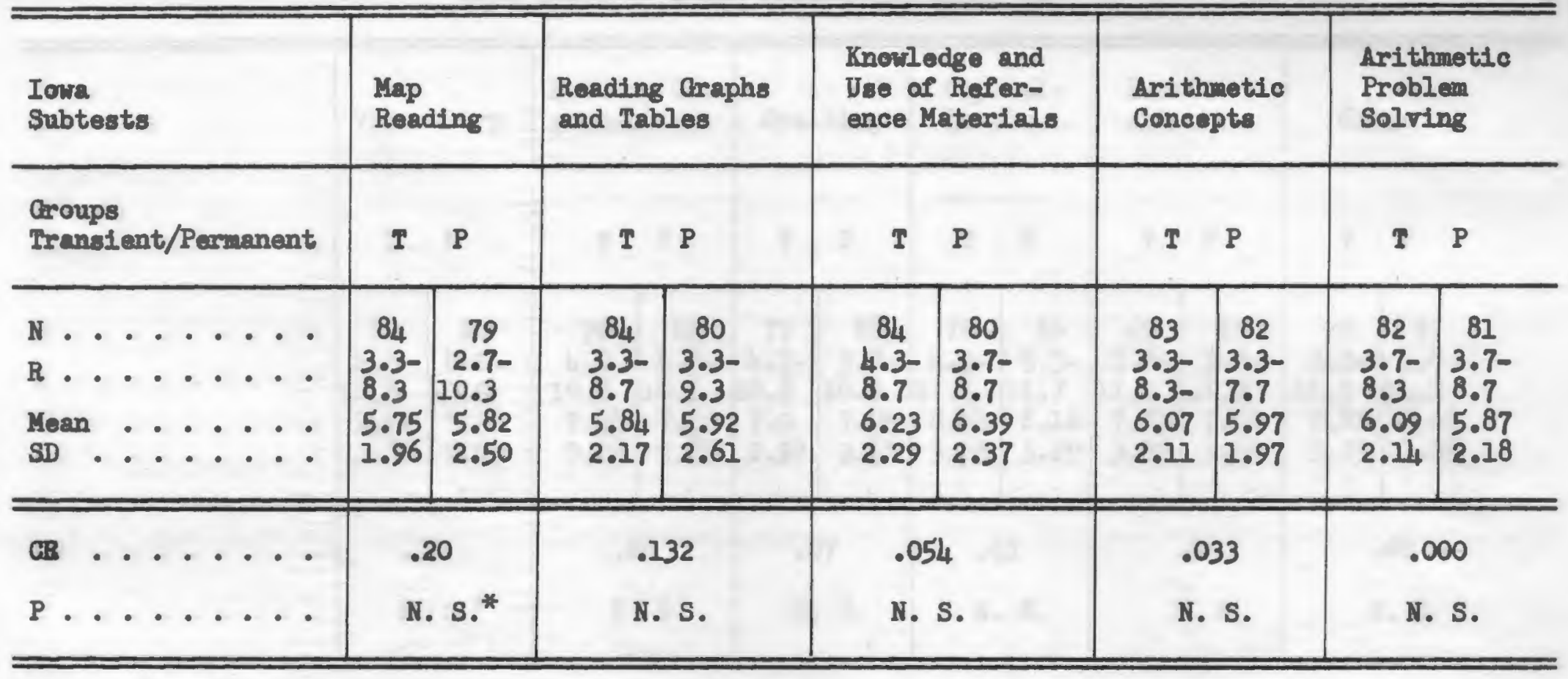

*iot signifioant at the .10 level 
TABLE 4

IOWA TESTS OF BASIC SKIIIS FOR CRADE SIX

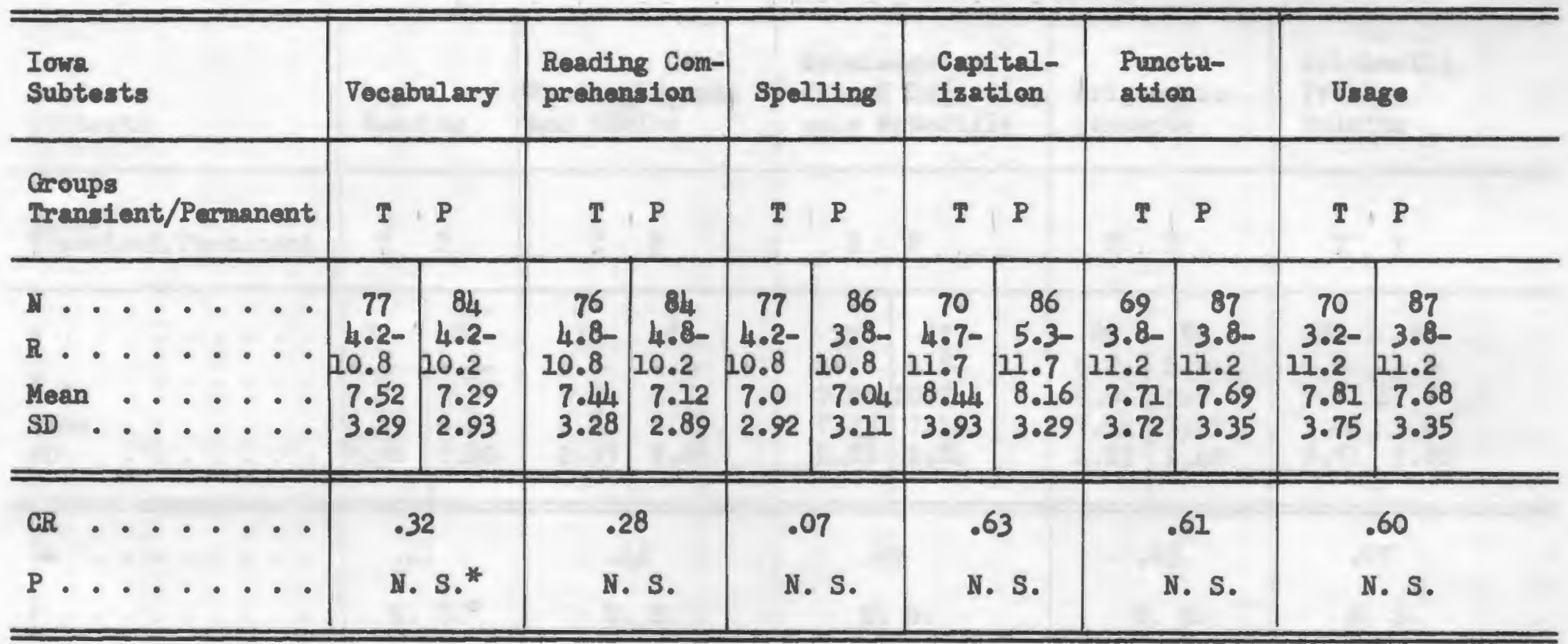

*ot aignificant at the .10 level 
TABLE 4 - Continued

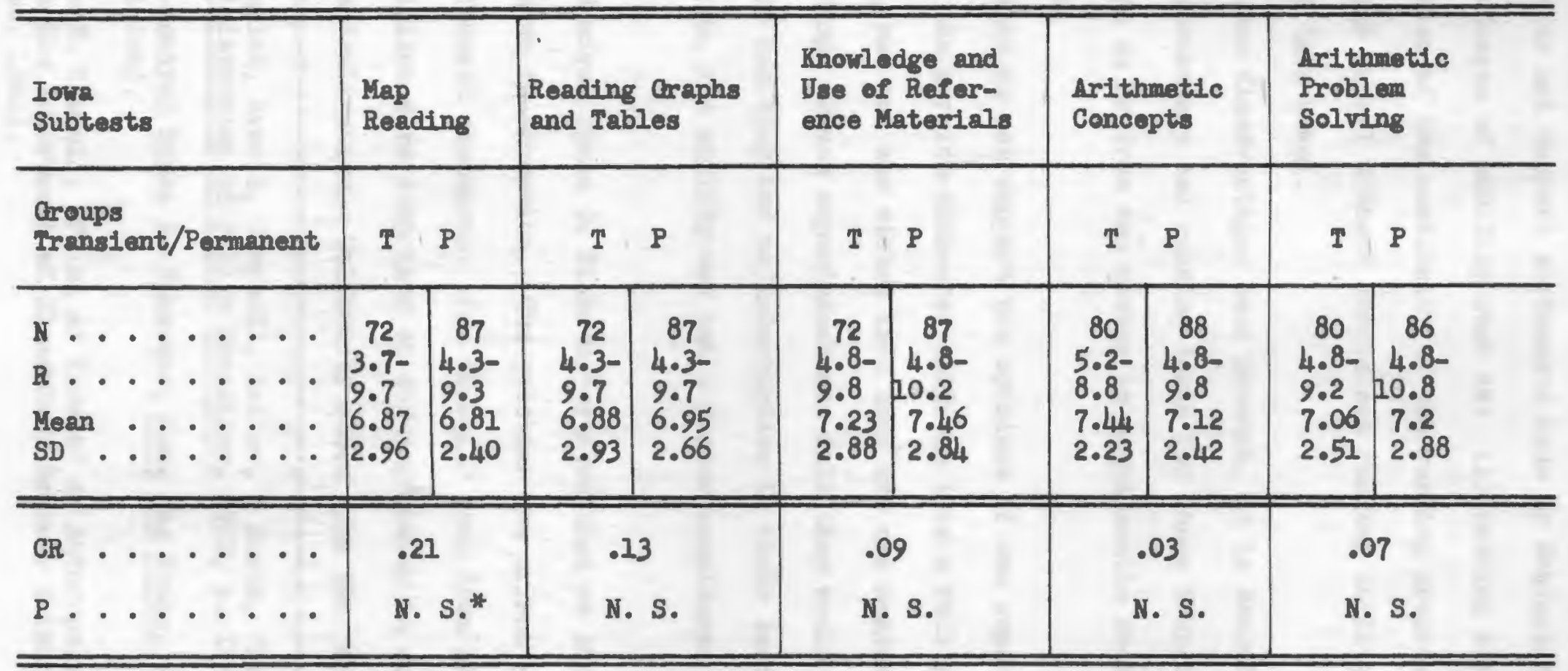

Not olgntrioant at the .10 level 
The results of the I. T. B. S. support this statement. Contraivise, they do not support statements made by Wahlquist pertaining to the disadvantages of mobility such as: (I) reading difficulties from interruption of the continuity of the reading program, (2) arriving in high school without sufficient reading ability to carry on the work at this level.

Had these disadvantages been present, it is doubtful that the means on the vecabulary and reading tests for these transient children world show them to be from two months to eight months above the national norms.

The tests do not support the opinions of one superintendent who felt that the sarvice-connected children lose a full year after sevaral moves, and one who stated that they are six months to a year behtind in reading. Seven superintendents felt they would have progressed farther bad they had no interruption in their learning. This fact may be true, for ability was not a factor considered in this thesis.

Vice-Admiral Hyman G. Rickoter ${ }^{2}$ stated that we should have federal standards in education. The question now arises as to the recessity of federal standards. Dr. Kimball 3 read from his paper that the Brazilians were surprised at our uniformity in education without any centralization. Uniformity comes from the vast number

IWahlquist, Arnold, Campell, Reller, \& Sands, "Pupil Accounting", The Adarinistration of Poblic Education, 1952, p. 173.

2Tice-Iduiral Hyman G. Rickover, Meet the Press, January 24 , 1960. (Talevision).

3solon T. Kimball, "Point of Vier of an Anthropologist", (Paper read at the. Bopartment of Flementary Schools Principals. I. B. A., Warch, 1961). 
of noetings of educational groups throughout the country and also the creellent textbooks which are available to 2.1 .

Scholastically, mobility seems to have presented no difficulties for these transient children of service-connected parents. Deficiencies may exist in the lower grades, but before any statement is made, a study of these three grades is advisable. Suparintandents who serponded that transient children were below grade in reading were referring to all six grades. Possibly their answers may be based on parfermances in the first three grades.

\section{Characteristics}

Characteristics of all transient and perwanent children were totaled as a group and not by grade. These then were tabulated and analysed statistically by the use of the chi-square tochnique. StaHistical results show the characteristics between the two groups to have practically no significance except in resourcefulness, shyness, athusiasm, punctuality, adaptability, and persistency.

Transient children were found to be more resourceful, adaptable, onthusiastic, and parsistant. Permanent children were rated higher in punctuality and shymess.

Table 5 presents the results of the characteristics between the transient and permanent children. The tables show the number of children rated by the teacher, the chi-square result, the degree of freedom and the results from the table of chi-square values. Sufficient evidence is lacking for concluding that the mivarses from which results were drawn differ in regard to most haracteristics. 
TABLE 5 - COMPARISON OF IHE CHARACTERISTICS BETWEFN THE TRANSIENT AND,

PERMAANENT CHILDRIEN IN

GRADES 4, 5, AND 6

\begin{tabular}{|c|c|c|c|c|c|c|c|c|c|c|c|c|c|}
\hline$a x$ & reot & eri & stiles & & & \multicolumn{2}{|c|}{$\begin{array}{l}\text { Resowrce- } \\
\text { fulness }\end{array}$} & \multicolumn{2}{|c|}{$\begin{array}{l}\text { Alert- } \\
\text { ness }\end{array}$} & \multicolumn{2}{|c|}{$\begin{array}{l}\text { Adapta- } \\
\text { bility }\end{array}$} & \multicolumn{2}{|c|}{$\begin{array}{l}\text { Creative- } \\
\text { ness }\end{array}$} \\
\hline \multicolumn{6}{|c|}{ Groups } & \multicolumn{2}{|c|}{ I $\quad$ P } & \multicolumn{2}{|l|}{$\mathbf{T}$} & \multicolumn{2}{|l|}{$T$} & $T$ & $P$ \\
\hline บะพ & ber & - • & - • & • & - & 216 & 243 & 216 & 243 & 215 & 243 & 215 & 243 \\
\hline$x^{2}$ & - & - & - & 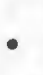 & - & \multicolumn{2}{|c|}{7.6437} & \multicolumn{2}{|c|}{4.2659} & \multicolumn{2}{|c|}{16.5615} & \multicolumn{2}{|c|}{.9540} \\
\hline df & - $\bullet$ & - & - $\bullet$ & & - & \multicolumn{2}{|c|}{3} & \multicolumn{2}{|c|}{3} & \multicolumn{2}{|c|}{3} & \multicolumn{2}{|c|}{3} \\
\hline $\mathbf{P}$ & - • & - & - & 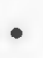 & - & \multicolumn{2}{|c|}{.10} & \multicolumn{2}{|c|}{.10} & \multicolumn{2}{|c|}{.01} & \multicolumn{2}{|c|}{.10} \\
\hline
\end{tabular}

TABLE 5 - Continued

\begin{tabular}{|c|c|c|c|c|c|c|c|c|}
\hline Guracteristics & \multicolumn{2}{|c|}{ Popularity } & \multicolumn{2}{|c|}{ Attitude } & \multicolumn{2}{|c|}{$\begin{array}{l}\text { Fintha- } \\
\text { siasm }\end{array}$} & \multicolumn{2}{|c|}{$\begin{array}{l}\text { Verbal } \\
\text { Expression }\end{array}$} \\
\hline $\begin{array}{l}\text { Groups } \\
\text { Rndent/Permanent }\end{array}$ & $T$ & $\mathbf{P}$ & $\mathbf{T}$ & $\mathbf{P}$ & $\mathbf{T}$ & $\mathbf{P}$ & $\mathbf{T}$ & $\mathbf{P}$ \\
\hline Lrumber ..... & 215 & 243 & 203 & 243 & 216 & 243 & 215 & 243 \\
\hline$x^{2} \ldots \ldots$ & \multicolumn{2}{|c|}{4.1451} & \multicolumn{2}{|c|}{1.4105} & \multicolumn{2}{|c|}{9.9815} & \multicolumn{2}{|c|}{.8432} \\
\hline df ....... & \multicolumn{2}{|c|}{3} & \multicolumn{2}{|c|}{3} & \multicolumn{2}{|c|}{3} & \multicolumn{2}{|c|}{3} \\
\hline$P \cdots \bullet \cdot \cdots$ & \multicolumn{2}{|c|}{.10} & \multicolumn{2}{|c|}{.10} & \multicolumn{2}{|c|}{.05} & \multicolumn{2}{|c|}{.10} \\
\hline
\end{tabular}


TABLE 5 - Continued

\begin{tabular}{|c|c|c|c|c|c|c|c|c|c|}
\hline pharactaristics & \multicolumn{2}{|c|}{$\begin{array}{l}\text { Work } \\
\text { Habits }\end{array}$} & \multicolumn{2}{|c|}{$\begin{array}{l}\text { Punctu- } \\
\text { ality }\end{array}$} & \multicolumn{2}{|c|}{$\begin{array}{l}\text { Care of } \\
\text { School Property }\end{array}$} & \multicolumn{3}{|c|}{ Honesty } \\
\hline Seoups & & $\mathbf{P}$ & $T$ & $\mathbf{P}$ & $\mathbf{I}$ & $\mathbf{P}$ & & & P \\
\hline Nuraber $\cdot . . \cdot$ & 215 & 243 & 215 & 243 & 215 & 243 & & 15 & 243 \\
\hline$x^{2} \ldots \ldots$ & 2.4 & & 10. & 3764 & 1.1 & & & 1.4 & \\
\hline$d f \cdots \cdots$ & 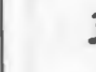 & & & & & & & & \\
\hline $\mathrm{P} \ldots \ldots$ & & 10 & & 02 & & 10 & & & \\
\hline
\end{tabular}

TABLE 5 - Continued

\begin{tabular}{|c|c|c|c|c|c|c|}
\hline Mneracteristics & \multicolumn{2}{|c|}{ Geficieney } & \multicolumn{2}{|c|}{ Shymess } & \multicolumn{2}{|c|}{ Agressiveness } \\
\hline $\begin{array}{l}\text { Croups } \\
\text { tynuient/Permanent }\end{array}$ & & $\mathbf{P}$ & $T$ & $\mathbf{P}$ & $\mathbf{T}$ & $\mathbf{P}$ \\
\hline Luwber . . . . & 215 & 243 & 215 & 243 & 215 & 243 \\
\hline$x^{2} \ldots \ldots \ldots$ & \multicolumn{2}{|c|}{1.2627} & \multicolumn{2}{|c|}{7.5289} & \multicolumn{2}{|c|}{3.0133} \\
\hline 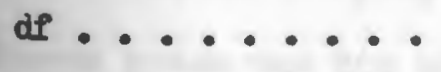 & \multicolumn{2}{|c|}{3} & \multicolumn{2}{|c|}{2} & \multicolumn{2}{|c|}{2} \\
\hline $\mathrm{P} \ldots \ldots$ & \multicolumn{2}{|c|}{$>.10$} & \multicolumn{2}{|c|}{$<.05$} & \multicolumn{2}{|c|}{$>.10$} \\
\hline
\end{tabular}


TUBLE 5 - Continued

\begin{tabular}{|c|c|c|c|c|c|c|}
\hline Araracteristics & \multicolumn{2}{|c|}{ Shorr Orf } & \multicolumn{2}{|c|}{ Parelstency } & \multicolumn{2}{|c|}{ Distractability } \\
\hline froups & & & $\mathbf{T}$ & $\mathbf{P}$ & $T$ & $\mathbf{P}$ \\
\hline Nuwber ..... & 215 & 24,3 & 215 & 243 & 215 & 243 \\
\hline$x^{2} \ldots \ldots$ & \multicolumn{2}{|c|}{1.3864} & \multicolumn{2}{|c|}{13.4246} & \multicolumn{2}{|c|}{2.9591} \\
\hline$d f \ldots . . .$. & \multicolumn{2}{|c|}{2} & \multicolumn{2}{|c|}{2} & \multicolumn{2}{|c|}{2} \\
\hline$P \ldots \ldots$ & \multicolumn{2}{|c|}{$>.10$} & \multicolumn{2}{|c|}{$<.01$} & \multicolumn{2}{|c|}{$>.10$} \\
\hline
\end{tabular}

The statistics show the transient children to be somewhat more resourceful than the permanent children at the 10 per cent level of confidence. This comes as no surprise. Here is one area where agreement was practically unanimous in the literature. These figures support the statement of Bloughl when he wrote that experiences in the Service provide a rich resource for school children. Children become a source of inportant information.

Kartin ${ }^{2}$ stated the importance of using the experiances of these mobile children. Here is the opportunity for the child to discover his place in the group.

As an example, the writer cites the case of a child in the fourth grade who did not excel in any one particular subject.

$I_{\text {Glemn }}$ 0. Blough \& Alan I. Dodd, "Children Are Their Orn Resources", Childhood Education, Vol. 34, . (September, 1958), p. 24.

Ziraneis Martin, Mlobility", Childhood Education, Vol. 34, (Boptenber, 1958), pp. 25-28. 
Howerer, he had resided on Okinawa when in the first grade. Plctures taken by his father kept these experiences vivid in his mind. When the obfldren were studying China, Gary brought the slides to school and was eapable of explaining the information presented by the slides. Cartainly this ohild and others like him have a feeling of adequacy and worth. Some of the edvational literature described the mobile child as lacking in adequacy and worth.

From the questionnaires received from superintendents, twentynine of these felt that the mobile children have rich experiences in history and geography. Even though no actual study was made, the opinions of superintendents seemed to support the resourcefulness of the transient ehildren.

Iransient children proved to be far more adaptable at the one per cent level of confidence than the permanent children. This also comes as no surprise to the writer. To cite an example, an orlentation day was held for children in the fourth and fifth grades in North Kingstorn who were to be transferred to another school in the tom for the following jear. These children were being uprooted for the first time. This meant a ienger distance from home and a wholly new school enviromment. Dissatiafaction was supreme anong the permanent children. They were reluctant to accept the move. Aftar an hour or so at the new school, they returned to the faniliar mrromdings which had been thair schoel for four or five years. Caplaints pervaded the stationary group whereas little opposition was marifested by the transient children.

Phillipsl stated that one concern for the transient child was Theational Administration and Suparvision, Vol. 43, (February, 1957). 
that of helping the pupil to adjust to his new environment. This statement seems to have no foundation, for the children from servicecomected fanilies adapt readily and participate in a new school mirement.

Among the disadrantages of transiency mentioned in the literature was found the following: (1) Difficulty in adjusting to a new aituation. (2) Boconing adjusted and accustomed to new surrowadings, friends, and teachers.

These disadrantages were opinions rather than actual studies. Iamond related from a stady of these children that the mobile child adapts very quickly. The present study concurs with this finding. Ancieties concerning the adaptability of the mobile child appear to have no foundation, for through Hamond's study and the results of this thesis, it was found that the transient children were wech more adaptable than the permanent children. These mobile children are accustomed to being uprooted and undoubtedly the majority of parants accept the move and all its advantages. This, in turn, is tranaferred to the child for children are apt to accept the views of the parents. Havy people are accustomed to change and have learned the proper adjustment to new situations.

Statistically, the mobile children were more enthusiastic than the permanent children at the five per cent level of confidence. The variety of schools attended and the new situations encountered tend to provide the child with more enthusiasn rather than boredom. Their curiosity is evidently not lost in an attempt to find

Irances Proctor Hamond, A Study of the Achievenent and Adjustment Patterns of Service-Connected children, pp. 42-42, p. 57 . 
socurlty. They have learned throagh experience how to adjust to a now ariroment, bringing with them their resources and enthusiasm.

Punctuality oridently means little to the transient children. In this area, the stationary children proved to be suparior at the two per cent level of confidence. The permanent children have continued throughout their lives in an unchanging enviroment. Baing puctual is routine in their lives; whereas, the mobile children are mprooted so many tines that punctuality means little to them. Nothing was mentioned in the literature read concerning this characteristic. Humand rrites that the mobile child has very nice classroom manners, and seems to have a highly developed sense of secial awareness. The atatistical analysis of the shy characteristic supporte Hamond, for it was found the pormanent children to be considerably more shy at the $5 \%$ level of confidence than transient. Statimary children have not had the opportunity of meeting the vast number of diffarent people and of learning to adjust to $a l l$ races, creeds, and secial classes. They are deeply rooted in their envirement with no horizantal spread. Mra Weymouth2 explained the situation by saying that the Mary personnel do not put down deep roots but their roots do spread horizontally. In this respect they grow socially and attempt to become acquainted with the people and commity in which they reaide for either a short or long peried of tine.

In the litarature, one disadrantage mentioned for the mobile

\section{Ibid.}

2urs. Iaure Weymouth, wife of the Captoin of the carrier, Lake Ghoplain. (Personal Interviow). 
children was having to learn in a few months what others have learned in several years. This may not be a disedvantage for in this study the mobile children were found to be highly more persistent at the 1\% level of confidence than the stationary. Again these children have learned through exparience exactly what is expected of them when they move from one school and community environment into another. In order to make a place for thenselves, they learn to be persistent in 211 that they do.

The four charactaristics in which the transient children excel seen to be somenhat connected. Their resourcefulness would have a tandency to make them more adaptable and enthusiastic. Bnthusiasm is uswally present when something new is atterpted. When it is discovered that their resourcefulness is of value, adaptability follows. Pordistency is the result of their offort to make a place for themselves in their new school enviroment.

These characteristics are outstanding in this particular commity. Whether they exist in others would necessitate more study. As was stated and explained in the first chapter, the community and school in which these children enroll is an average New Fngland town. Comptition may not be too great; consequently, these mobile children readily discover a place for themselves in school and commity life. Whantages of travel are outstanding but the permanent children are pradually having opened to them the wide vistas of knowledge through aseciation with these children and travel adventures with their parents. 


\section{Pertinent Information}

Pertinent information was obtained from office records, the teachers, and the children. This included the number of children coming from broken homes, the number of children having repeated a grade, the number entering outside activities, and the number of different sehools attended by the transient children.

By use of the ehi-square technique, no sigatficant difference was found in the two groups in regard to repeating a grade and entering outside activities. A great predominance of children was found to come from broken homes in the transient group as compared with the permanent group. This being so, a study of the characteristics between the broken home groups and the non-broken home groups was made. Another study comparing the differences between the ohildren coming from broken homes and non-broken homes in the trangient group was made.

In the comparison between children from broken homes and nonbroken homes in both groups, significant differences were discovered in such characteristics as alertness, creativeness, popularity, work habits, attitude, rerbal expression, honesty, and efficiency. The children from non-broken homes were superior in all these character18tics.

The folloring tables contain the results of the statistical analysis of these traits. The comparison between the chilldren from broken homes and non-broken homes in the transient group showed Armificant differences in such characteristics as popularity, attitude, work habits, punctuality, and honesty. Children from non- 
broken homes were superior in all these areas. Table 6 demonstrates the predominance of children from broken homes in the transient group whth a 1\% level of confidence for the total sample. This information mepports the opinions of teachers, principals, and clerks registaring entldren when they enroll in a school. It is not at all surprising to find three names in a family. There were two children registered in the Wickford Grammar School where the parents had one surname and each of the children had a surname different from each other and different from the parent's. A situation like this is not very common, but it is rather cormon to have children with different names than that of the parents.

Disciplinary cases appear to be outstanding in the children from broken homes. This statement is generally accepted but has not been substantiated. To determine whether any statistical significant differences existed among the range of characteristics under consideration in this thesis a chi-square comparison was made.

\section{TABLE 6 - COMPARISON BETWEEN BROKET HOMES AND NON-BROKEN HOMES IN TRANSIENTT AND PERMANESTT CHILDREN}

\begin{tabular}{|c|c|c|c|c|}
\hline Grade & Four & Five & $\operatorname{six} x$ & Totals \\
\hline $\begin{array}{l}\text { Broken Hewes/ } \\
\text { Mon-Broken Homes }\end{array}$ & $\mathrm{BH} \mathrm{NBH}$ & BH NBH & BH NBH & $\mathrm{BH}$ NBH \\
\hline $\begin{array}{l}\text { Transient ... } \\
\text { Permanent ... } \\
\text { Totals ..... }\end{array}$ & \begin{tabular}{r|l}
15 & 59 \\
8 & 80 \\
23 & 139
\end{tabular} & \begin{tabular}{r|r}
7 & 57 \\
5 & 67 \\
12 & 124
\end{tabular} & \begin{tabular}{r|r}
15 & 81 \\
7 & 82 \\
22 & 163
\end{tabular} & \begin{tabular}{l|l}
37 & 197 \\
20 & 229 \\
57 & 426
\end{tabular} \\
\hline 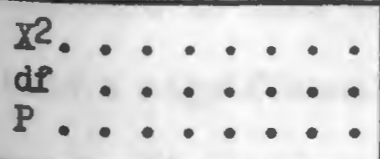 & $\begin{array}{l}4.1357 \\
\quad 1 \\
<.05\end{array}$ & $\begin{array}{c}.7195 \\
1 \\
>.10\end{array}$ & $\begin{array}{c}18.7942 \\
1 \\
<.01\end{array}$ & $\begin{array}{c}7.0859 \\
1 \\
<.01\end{array}$ \\
\hline
\end{tabular}


The first comparison in Table 7 reports the differences in macteristics between the children from broken homes and non-broken homes in the totals of transient and perwanent children.

No significant differences were found in such characteristics as wosourcefriness, adaptability, onthusiasm, penctuality, shyness, aressireness, persistency, distractibility, and care of school pmoperty. 111 others proved to be significant.

From the results, it appears the children from broken homes have a "no-care". attitude. They are significantly less alert at the 5\% level of confidence and less popular at the $2 \%$ level of confidence than children from non-broken homes. Whereas no significant difference was found between the transient and permanent children in creativeness, 2 definite significance at the $5 \%$ level of confidence shows between ehtldren from broken homes and non-broken homes. Three characteristics which might have some bearing on their scholastic achievement are varbal expression, work habits, and officiency. The children from broken homes showed a deficit in all these areas at the $2 \%, 5 \%$, and $10 \%$ levels of confidence respectively. Honesty proved to be more Agnificant at the 1\% level of confidence than all other characteristics.

From these results, the children from broken homes may reveal vatotanding disabilities. In some aspects, these results may have a dafinite bearing on the opinions of teachers and principals when reference is made to outstanding difficulties with the mobile children since a significantly larger number of these come from broken homes. It is important to note that no significant differences were established in the area of adaptability. Again these children have 
learned through mobility, in the howe or elsewhere, how to adapt to any given aituation.

$$
\begin{gathered}
\text { TABLE } 7 \text { - BROKFAN HOMES AND NON-BROKERT } \\
\text { HOMTS - TRANSIENT } \\
\text { AND PERMANEANT }
\end{gathered}
$$

\begin{tabular}{|c|c|c|c|c|}
\hline Anracteristics & $\begin{array}{l}\text { Resource- } \\
\text { fulness }\end{array}$ & $\begin{array}{l}\text { Hlert- } \\
\text { ness }\end{array}$ & $\begin{array}{l}\text { Adapta- } \\
\text { bility }\end{array}$ & $\begin{array}{l}\text { Creative- } \\
\text { ness }\end{array}$ \\
\hline $\begin{array}{l}\text { Croups - Broken Homes/ } \\
\text { Ion-Broken Homes }\end{array}$ & BH NBH & BH NBH & BH NBH & BH NBH \\
\hline Irumber . . . . & 57402 & 57402 & 57401 & 5740 \\
\hline$x^{2} \ldots \ldots$ & 4.7940 & 8.7439 & 4.7217 & 9.0597 \\
\hline df ....... & 3 & 3 & 3 & 3 \\
\hline$P \ldots \ldots$ & $>.10$ & $<.05$ & $>10$ & $<.05$ \\
\hline
\end{tabular}

TABLE 7 - Continued

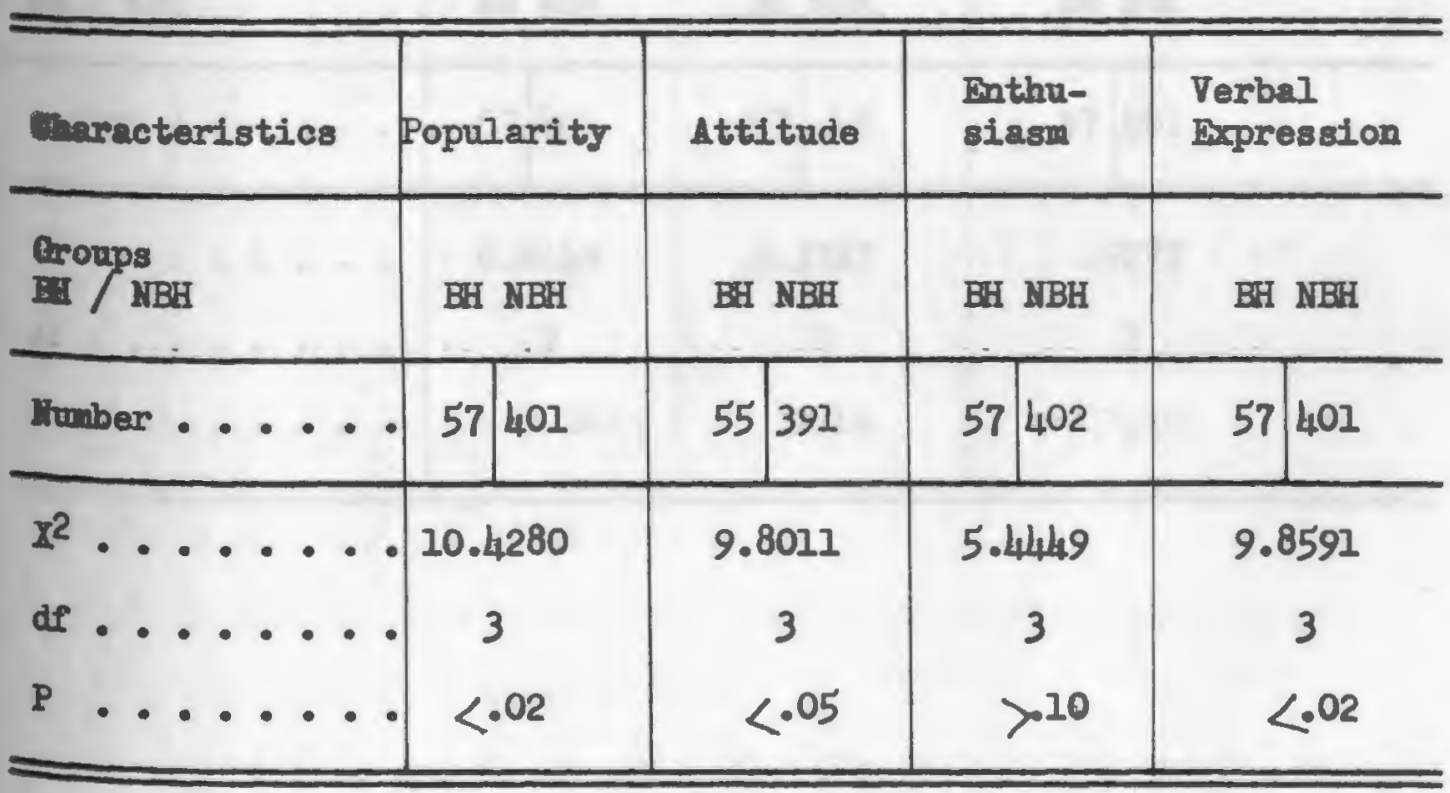


TABLE 7 - Continued

\begin{tabular}{|c|c|c|c|c|c|c|c|c|}
\hline Maracterlstics & \multicolumn{2}{|c|}{$\begin{array}{l}\text { Work } \\
\text { Habits }\end{array}$} & \multicolumn{2}{|c|}{$\begin{array}{l}\text { Punctu- } \\
\text { ality }\end{array}$} & \multicolumn{2}{|c|}{$\begin{array}{l}\text { Care of } \\
\text { School Property }\end{array}$} & \multicolumn{2}{|c|}{ Honesty } \\
\hline Groups $/ \mathrm{NBH}$ & \multicolumn{2}{|c|}{ BH NBH } & \multicolumn{2}{|c|}{ BH NBH } & \multicolumn{2}{|c|}{ BH NBH } & \multicolumn{2}{|c|}{$\mathrm{BH}$ NBH } \\
\hline Junber . . . & 57 & 40 & 57 & 401 & 57 & 401 & 57 & 401 \\
\hline$x^{2} \ldots \ldots$ & 8.7 & 358 & 5.5 & 5944 & & 8455 & 11.6 & 156 \\
\hline $\mathrm{d} f \ldots \cdot \cdots$ & & 3 & & 3 & & 3 & 3 & 3 \\
\hline $\mathrm{P} \ldots . . . \cdot$ & & .05 & & .10 & & 7.10 & & .01 \\
\hline
\end{tabular}

TABLE 7 - Contimued

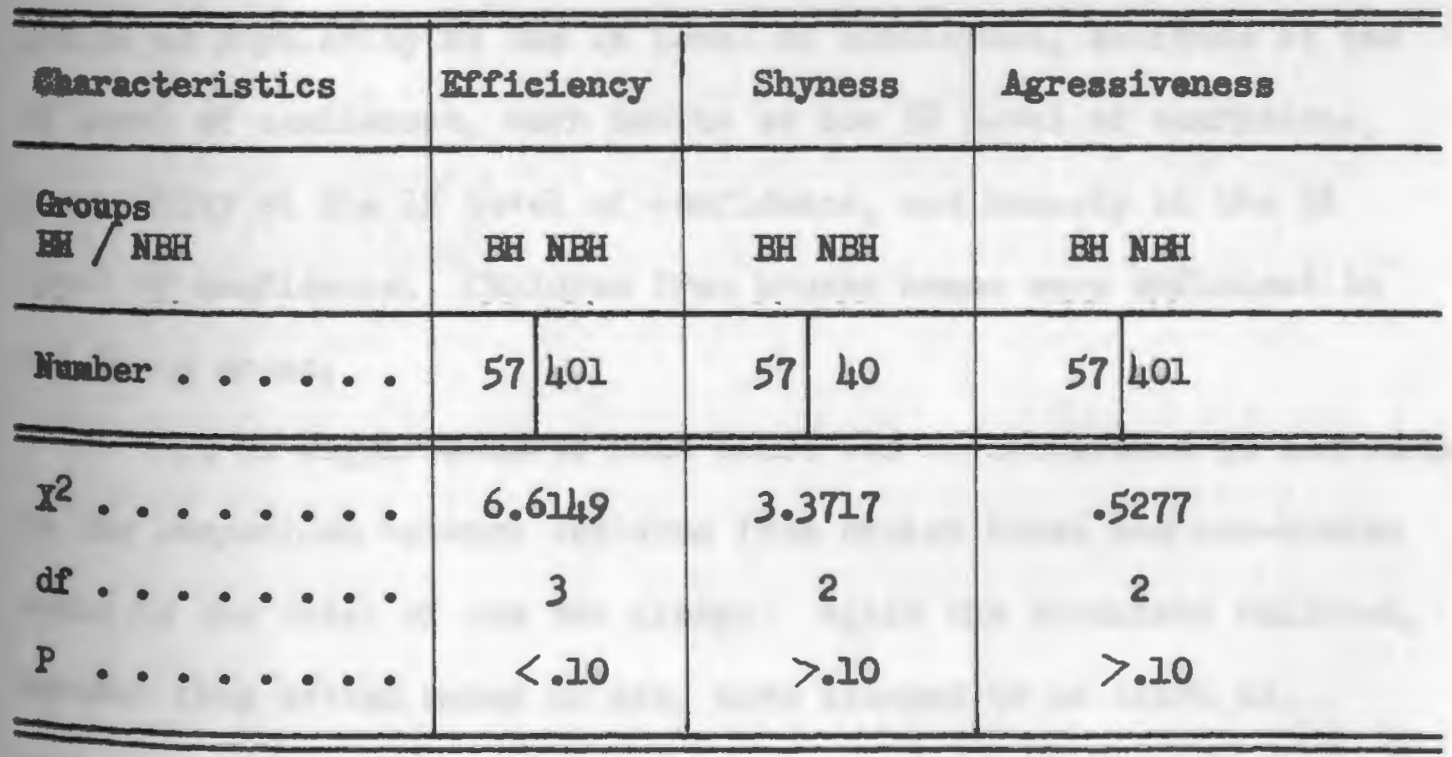


TABLE 7 - Continued

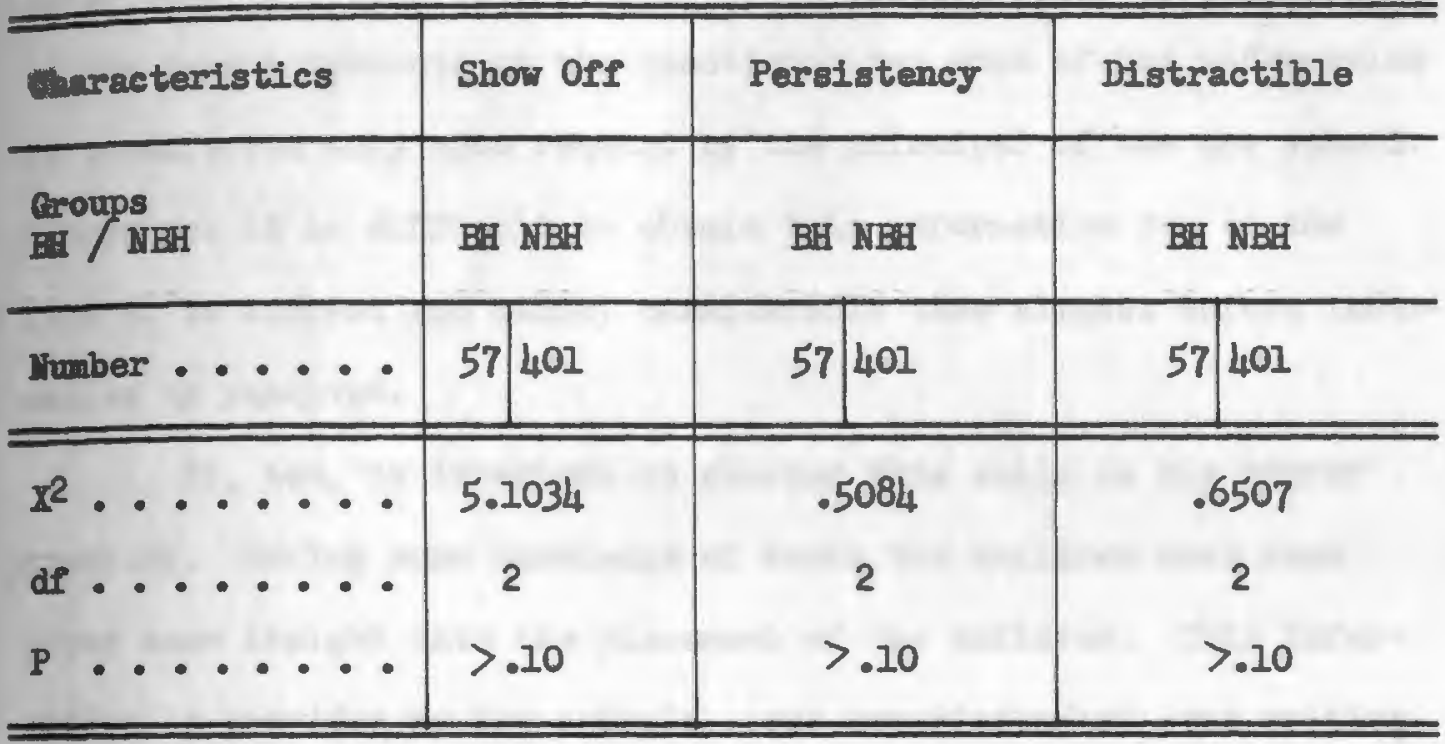

In Table 8 is found the comparisons between children from broken homes and non-broken homes in the transient group of children. Significant differences were established in such character1stics as popularity at the $2 \%$ level of confidence, attitude at the 2\% level of confiderce, work habits at the $5 \%$ level of confidence, pmetuality at the $1 \%$ level of confidence, and honesty at the $5 \%$ level of confidence. Children from broken homes were deficient in all these areas.

It is significant to note there was no difference in alertness in the comparisen between children from broken homes and non-broken homes in the total of the two groups. Again the transient children, whether from broken homes or not, have learned to be alert to situations in their environment.

It appears from this study that more outstanding problems wist in children from broken homes.

In this broken homes area, it is important to note pertinent 
information concorning the papil's past performances. Phillipsl lists this as one of the problems of mobility. From the responses of the superintendents on the questionnaires, most of the information is transfarred only upon request by the principal of the new school. Oftentimes it is difficult to obtain this information due to the lack of an address and hence, considerable time elapses before information is received.

It, too, is important in placing this child in his proper grouping. Having some knowledge of books the children have read gives some insight into the placement of the children. This information is provided by few schools - one superintendent even writing that he saw little value in forwarding this kind of information. The writer feels there is considerable value in this information. In Horth Kingstown, a child recently transferred from an American school in Cermany. With the cunulative records were the book and page in which the child was reading. Since there are four third grades in the butlding, the placement of this child in the proper group to make adjustment simpler was facilitated by the information from the reading list. Information readily available pertaining to this particular child was almost invaluable. As time progressed, problems may arise but due to all of the information recoived, it is the opinion of the writer that these problens will be minimized.

Table 9 reveals no statistically significant difference botween children from either group in the repetition of a grade. 
TABLE 8 - COMPARISON OF THE CHARACTERISTICS

BETWEEN TRANSIENAT CHIIDREN FROM BROKDN HOMES AND NON-BROKKNI HOMES

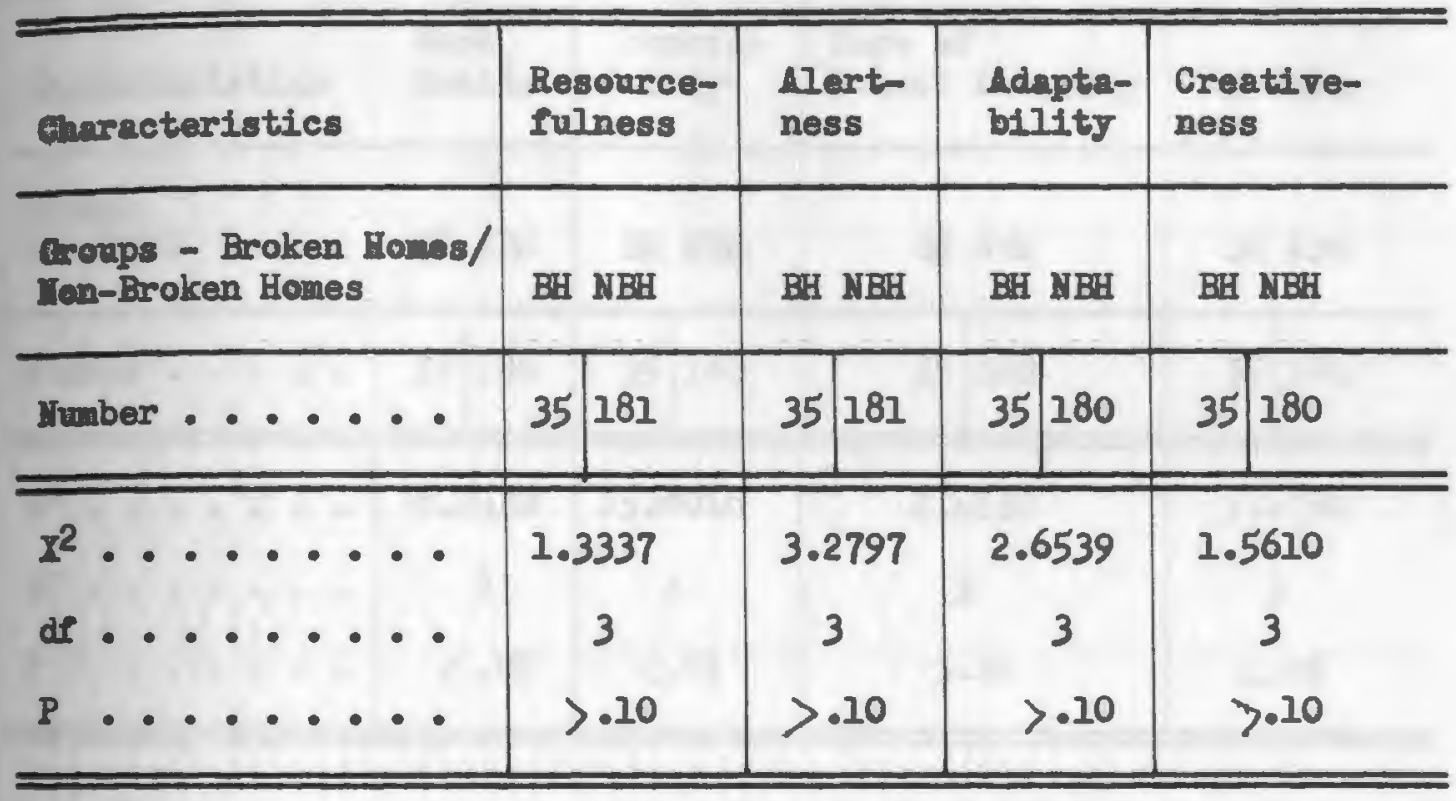

TABLE 8 - Continued

\begin{tabular}{|c|c|c|c|c|c|}
\hline Ghuracteristics & Popularity & Attitude & $\begin{array}{l}\text { Fathu- } \\
\text { siasm }\end{array}$ & $\begin{array}{l}\text { Verba } \\
\text { Expre }\end{array}$ & ession \\
\hline $\begin{array}{l}\text { Croups } \\
\text { / YBH }\end{array}$ & BH $\mathrm{NBH}$ & BH NBH & BH NBH & $\mathrm{BH}$ & NBH \\
\hline Inuber ..... & 35180 & 35170 & $\begin{array}{lll}35 & 181\end{array}$ & 35 & 180 \\
\hline$x^{2} \ldots \ldots$ & 9.7615 & 10.3536 & 3.0493 & \multicolumn{2}{|c|}{5.9256} \\
\hline df ....... & 3 & 3 & 3 & \multicolumn{2}{|c|}{3} \\
\hline$P \ldots$ & $<.02$ & $<.02$ & $>\cdot 10$ & \multicolumn{2}{|c|}{$>\cdot 10$} \\
\hline
\end{tabular}


TLBLE 8 - Continued

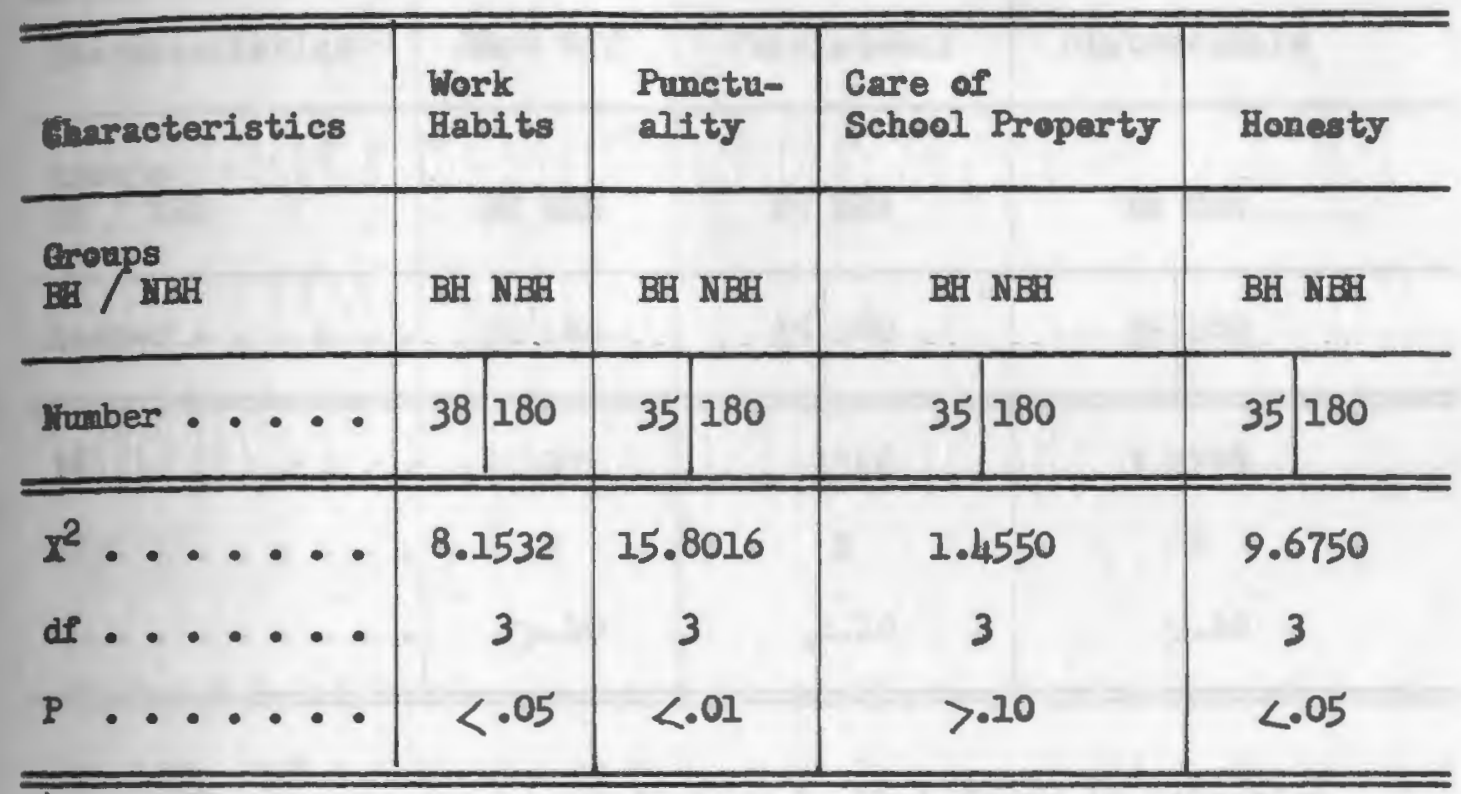

TABLE 8 - Continued

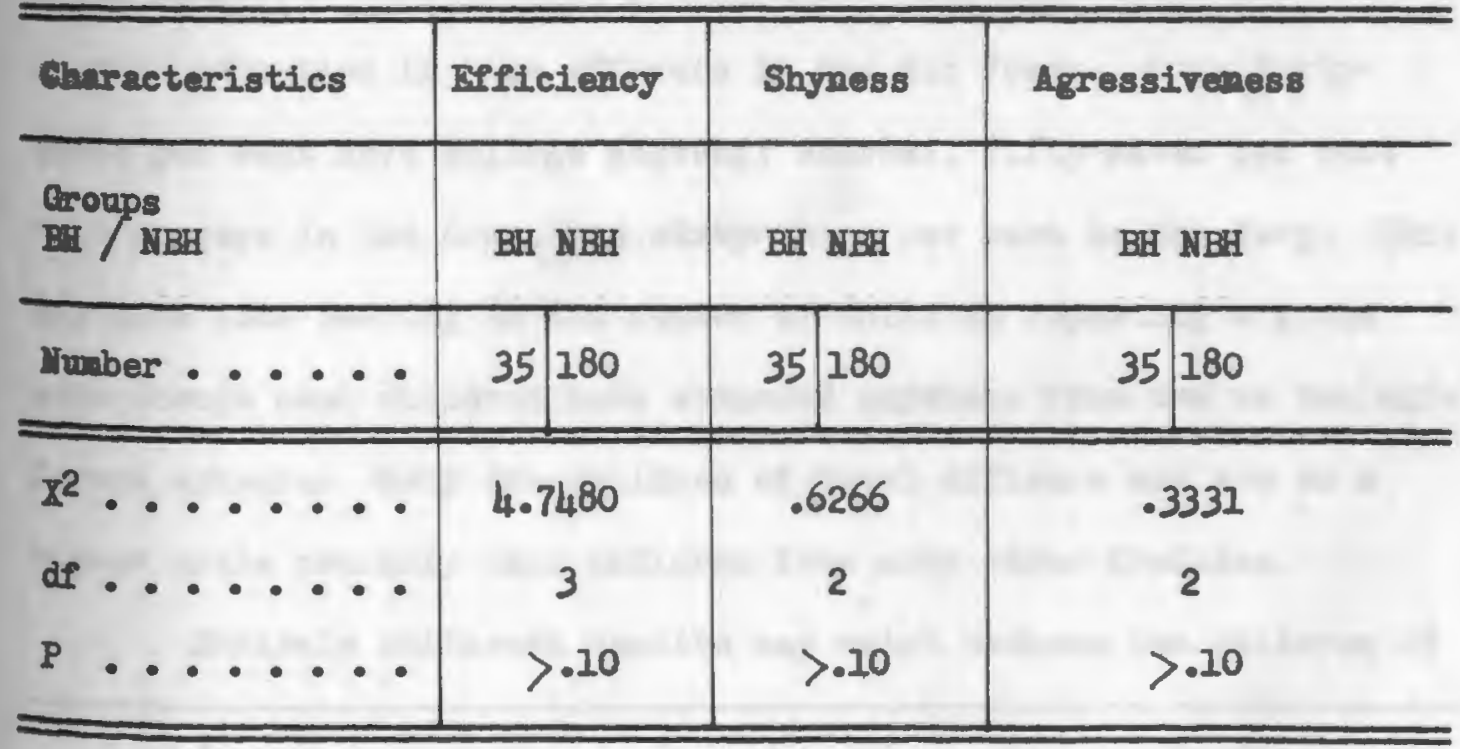


TABLE 8 - Continged

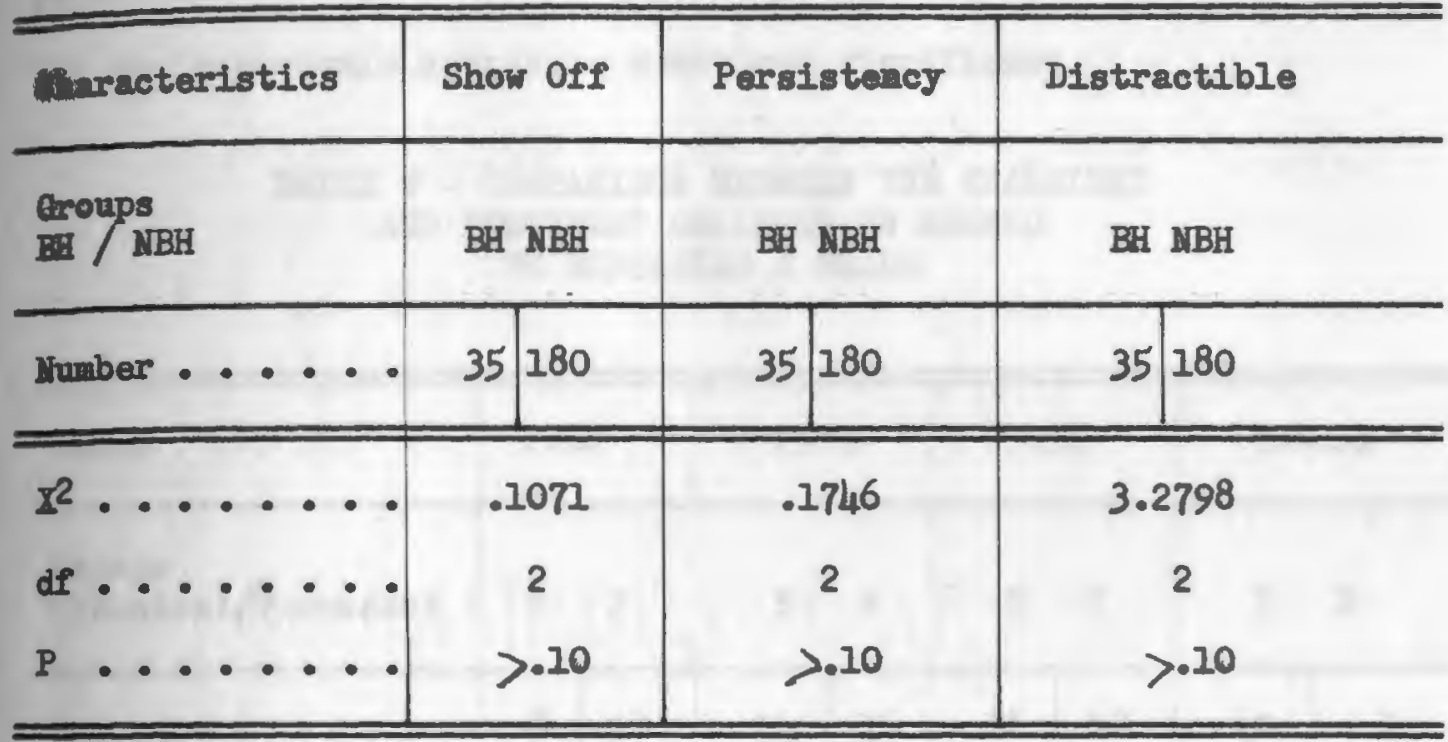

These data are contradictory to that found in Larsen's atudy. He found that children changing schools are four times as likaly to fall a grade as those who stay in one school.

Areas do differ and the majority of transient children in Yorth Kingstown come from Navy families. Newrweek ${ }^{2}$ notes the lack of a solid edueation in line officers in the Dir Force. Only fortythree per cent have college degrees; whereas, fifty-seven per cent hold degrees in the Army, and sixty-three per cent in the Iavy. This may have some bearing on the number of children repeating a grade even though some children have attended anwhere from two to ten diffarent schools. Many are children of Naval officers and are on a higher scale secially than children from many other families.

Intirely different results may exist between the children of

${ }^{1}$ Dr. Robart E. Larsen, New York Times, Section IV-BII, (September, 1955).

2Mewsweak, "The Lag in Brain Power", Vol. LVI, (October 31, 1960), p. 57 . 
digratory workers and those in a stable popralation. The shifting ppralation of migrant workers is largely economic in nature; hence, the secio-economic status is doubtless significant.

\section{TABLE 9 - COMPARISON BETWEEN THE TRAISIHAT \\ AND PERMANENT CHILDREN IN RECARD \\ TO REPEATING A GRADE}

\begin{tabular}{|c|c|c|c|c|c|c|c|c|}
\hline Crade & \multicolumn{2}{|c|}{ Four } & \multicolumn{2}{|c|}{ Five } & \multicolumn{2}{|c|}{ Six } & \multicolumn{2}{|c|}{ Totals } \\
\hline $\begin{array}{l}\text { Groups } \\
\text { thrensient/Permanent }\end{array}$ & $\mathbf{T}$ & $P$ & $\mathbf{T}$ & $\mathbf{P}$ & $\mathbf{T}$ & $\mathbf{P}$ & $\mathbf{T}$ & $\mathbf{P}$ \\
\hline Retarded .... & 8 & 10 & 14 & 16 & 18 & 18 & 40 & 44 \\
\hline Iot Retarded . . . & 66 & 79 & 50 & 56 & 63 & 7 & 179 & 206 \\
\hline Totals $\ldots .$. & 74 & 89 & 64 & 72 & 81 & 89 & 219 & 250 \\
\hline$x^{2} \ldots \ldots . .$. & & 50 & & & & & & 72 \\
\hline df ....... & & 1 & & 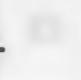 & & & & \\
\hline $\mathrm{P} \ldots \ldots . .$. & & 20 & & 95 & & 10 & & 10 \\
\hline
\end{tabular}

Iytel stated that transients tend to have little comnunity interest. Others in the literature mentioned a lack in comnunity interest. Table 10 conflicts with this statement, for here we find no igaificant difference between the two groups. Children are ancious to join Cub Scouts, Girl Scouts, Bromies and Boy Scouts. Keny are active in church activities and play an important role in school events.

I Goorge C. Kyte, The Principal at Work, p. 40. 
Hawnond found that parental opinions of transient puplls preved that the moblle ehild gets started imodiately on class projocts, joins clubs, and goes out for the athletic teams.

The socio-econciatc groups mentioned by Hamond are similar to those of North Kingstemn. This may have a bearing on their interest in the comunity. Deficiencies may exist in other areas, appecially those of wigrant children or of Maxican of Puerto Rican parantage.

TARTE 10 - COMPARISON BETWETI CHIIDREN IN THE TRANSIENT AND PERMANENT GROUPS IN REGARD

TO DNTERING OUTSIDE ACTIVITIES

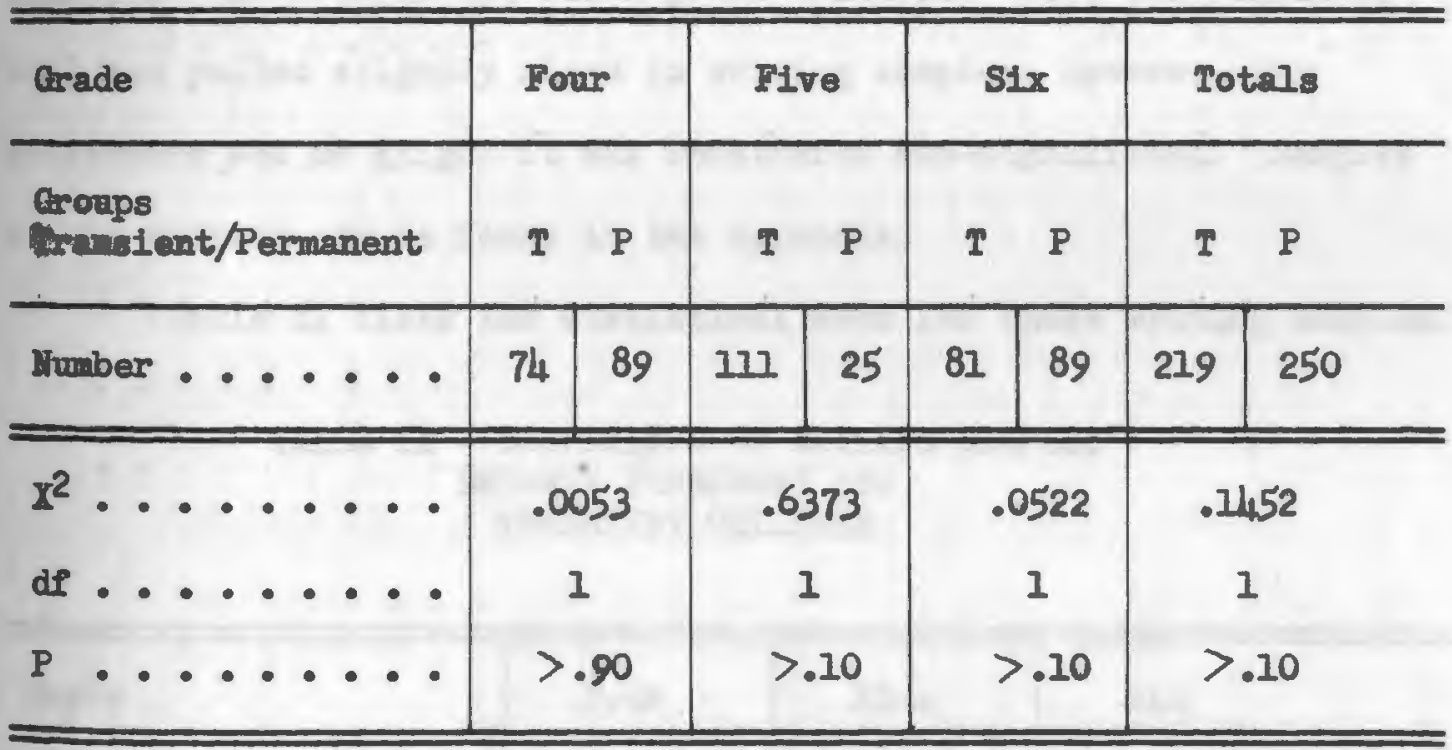

Table 1, Chapter III, page 49, shows the number of different echools the transient children have attended. The continual upreoting of these children from one enviroment to another seems to have had no affect on their scholestic achievement or characteristics. If anything, the specific characteristics upon which the transient Agjustment Patterns of Service-Conñected Children, 371.26. 
abildren outrated the permanent children were much to their advantage. It is pessible that these mobile children will be better prepared to living in a changing world than the permanent children. They are learning to live with change, learning how to adjust to new surrowndings, and how to meet new poeple, make friends, and live with all peoples regardless of race, creed, or social status.

\section{Uriting Samples}

Writing saples analysed statistically through use of the ahi-square technique reveal no significant difference between the transient and permanent children. If any difference at all were noted, it occurred in the sixth grade children. Here the permanent children pulled slightly ahead in writing samples; however, the dfference was so sight it was considered non-significant. Samples of the writing may be found in the appendix.

Table 11 lists the statistical data for these wititing samples.

\section{TABLE 11 - COMPARISON OF WRITTING SAMPLES BETWEEA PERMANENNT AND TRANSIENT CHIIDREN}

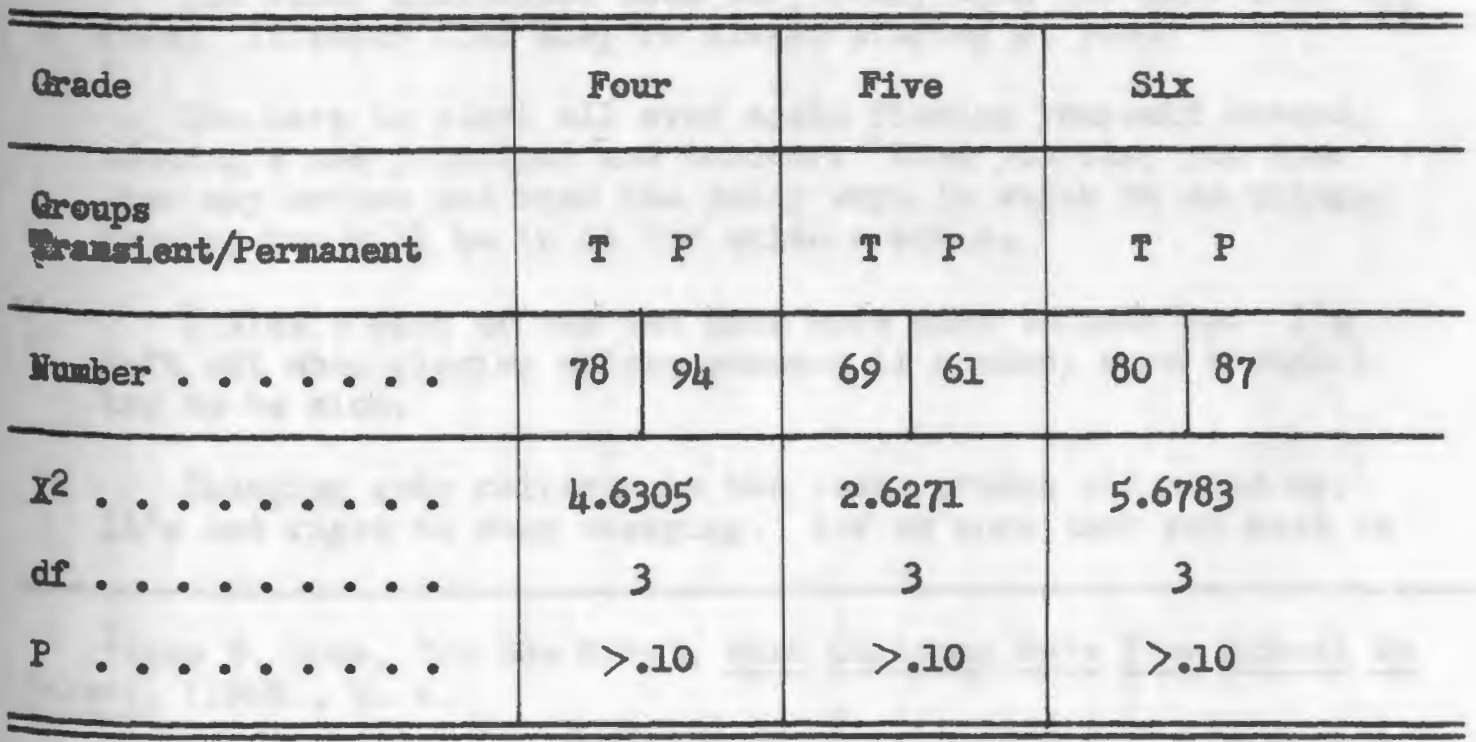


Lanel interviewed children concerning their impressions of changing schools. These impressions are listed on page thirtjuene Chapter II, in this thesis. An analysis of the writing samples of the Horth Kingstown transient children shows this concern to be gimilar to those reported by Lane. These children, on the whole, were concerned about meeting new friends and leaving the old friends. They worried about whether or not they would be behind or ahead in their school work. Many felt the change at the beginning of the year was all right but did not care for a change during the school term. Kany, in fact the majority, felt changing schools was an adventure and a challenge; however, they expressed a desire to stay in one school system at least two or three years. Many, too, mentioned that it took very little time to adjust to a new school. Following are some of the thoughts written by children

\section{thenselves:}

I don't like changing schools because I feel like a dunce not knowing where things are and do not like it for all the confusion.

It sure is a big and horrible thing to change schools.

The other classmates seem very funny when you walk into the room. It seems like they're always staring at you.

You have to start all over again finding yourself around, meeting a new principal and teacher. When you stay you know your way around and know the daily ways in which to do things; knowing you will be in it for quite a while.

I miss a week or two and have more work to make up. I'n laft. out when playing unless someone is needed, even though I try to be nice.

Changing gets children in the lower grades all mixed up. It's not right to koep changing. You no more than get used to

I Bess B. Lane, "On the Move", When Ghildren Yove From School To School, (1960), p. 4 . 
one school and the very next year you have to go to another and get mixed up all over again.

I think all schools should teach the same things the same way.

If you're shy and bashful like me you won't get anywhere in Iffe so ny impression of changing schools is not so good.

When I change from one school to another at any time of the jear, I wish sometimes that wy father wasn't in the Navy. I have to leave my old friends and yy old school. When we get to our destination and move in, I feel lonely. When I try to make friends, I start out trying to find their hobbies, favorite sports, and all about the neighborhood. When I start in a new nocol, I may not like the building, but I'm glad I have a teacher and a place to go to sehool.

Personally, I think it's for the birds, having to pull up your roots in a place just when you are beginning to feel at houe and go to a new school where you don't know half the things the kids know. When my father gets out of the Navy, I want to settle dorm in Tennessee and go to the same school for the rest of sy school yoars.

Different schools use different ways of teaching. You wight have studied some subject your new class is studying now. This makes you bored.

I wonder what the new school is like, the new home and what lind of pets I can have and what wild life is in the area.

In a new place everything is strange. Felt bad leaving Key West, but when I came to Rhode Island I was comfortable because the teachers understood me.

I don't like to have to get used to a new school. I couldn't remember what room I was in and did't know where the room was. It's been rough on me because every room I've been in I've had at least two teachers.

I lose friends I have just met. I don't stay in one place too long so that I can say I grew up with her.

I get nervous when I go to a new school. One school teacher called me sunshine. I liked that.

I wish I could stay in one place and have the same friends all my life.

Changing schools is fun at first, but it will not help anybody with their work. I have been to five schools and they are 11 different. 
As an experienced person you should try to move in the summer and always pick a good school. I would like to move every three jears because I could learn different methods, make different friends.

The reason I like it is that going to more than one school means learning from different books and by different methods. If the student tries to do things well, he will try to take the good parts of one school and add them with the good parts of another school. The only thing that I don't like about moving is that I grow used to a method used in one school, I move, and than a different systen is used.

I don't compare a school by the way it looks but by the way the people in the school act and show their appearance.

Aftar a few weeks you get used to it and it feels like home.

Sometimes you run into old friends you haven't seen in a long time.

If you stay in one school too long you might get tired of it.

Sometimes I get tired of the surroundings, the books, and even the subjects I take. In a new school you have different subjects and activities.

When you go into a new school you have an impression that you don't like the school. But after a little while you get to know the school better and you will like the school.

Changing schools is a good thing for this reason. Iynnbrook School was the first grade school I went to. It was in Bothesda, Maryland. The teachers, the chilldren, and. I exchanged gulte a few ideas. But after a while our ideas were fixed. We didn't have any ideas to come and replace the old ideas of ours.

But when I moved to Rhode Island, I had new friends, new texchers, and we exchanged new. Ideas and learned new things.

I think as you move and go from school to school you learn new ideas and you will benefit by them in the shart run and the long run.

I miss a lot of school moving from place to place. Some schools, the teachers are nice. In other places the principals ware mean and made the teachers be mean to us. But in this school everybody is nice.

I think you should change. Iou get to meet more people, teachers and biggar schools. Iou go to dofferent places and have new neighbors. I like to travel.

I like to change and see new children. I hate seeing the same children all the time. 
I like moving because I like to see how differently teachers teach. I enjoy meeting different people.

You go through famous cities and towns.

I like to go to each state and meet different people. You can meet mean people, nice and kind people, and Rhode Island is a friendly state. 


\section{CHAPTER V}

\section{CONCLUSIONS AND RECOMERDATIONS}

The fundamental concern of this study has been to determine whother any statistical significant differences exist in the academic sohievement and characteristics between the permanent children and the transient children in grades, four, fire, and six in the town of Horth Kingstorm.

Questionnaires from superintendents expressed doubt as to the reading and arithmetic achievement of these transient children. Iufty-four per cent of these superintendents felt the transient child might have progressed farther in reading had they had no tuterruptions in their schooling. A similar reaction applied to arithmetic. Iiterature read supported the opinions of the superintendents. The majority of superintendents felt that the serviceconnected child adapted readily to a new situation. This contradicted the literature of Phillipsl who was concerned about helping the transient child to adjust to a new situation.

Literature reviewed expressed concern for sound growth and adjustment of the mobile child. This concern included repeating a grade due to interruptions in schooling, leaving old frlends, loss

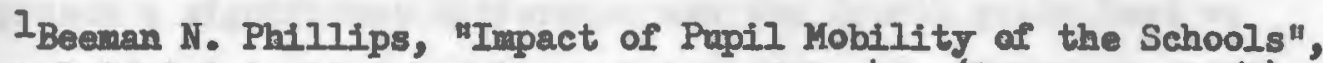
Fencational Administration and Supervision, Vol. 43, (Fobruary, 1957). 
of cariosity in an atteapt to find security, below grade level in reading and arithmetic, inability to make friends, lack of adequacy and worth, reading difficulties, little commity interest, failure to adjust, and lack of records of the children from previous schools. Advantages mentioned in the literature were fow except for the epportunity of travel which is open to the transient child. The moviledge gained from such a situation is a rich resource for children. These experiences, if used in the classroom, aid the transient child in his adjustment to a new group. Other advantages elted were learning to adapt to a new siturtion, resourcefulness, and alertness.

Questionnaires from auperintendents supported the literature concerning the child's academic achievement and resourcerviness. However, the majority of superintendente felt the mobile child had little or no difficulty in adjusting to a new school enviromnent. Uniformity in the forwarding of records seemed lacking in these impact areas. The majority of superintendents reported sending a cumulative record only when requested by the principal of the new school. This situation results in a loss of several days bafore records are received and may result in problems which might have been avoided had records been available immediately.

Results of the Iowa Tests of Basic Skills revealed no otatistical significant differences between the two groups of children comprising the sample for this study. The only test which began to approach a significant difference was the fourth grade test on map reading. Here the transient child appeared to be slightly superior. However, a critical ratio test of the mean differences 
proved even this test to have no significant difference.

This being so, these data do not sxpport the opinions of the twenty superintendents who felt the reading sidll of the mobile ahild would have progressed farther if there were no interruptions in their learning. Teachers also felt the mobile children were not up to grade level. The problens in reading of transient children are outstanding and seem to offret the average and above average alildren in their reading ability. The Teacher's Manual for the Iowa Tests of Basic Skillel states that one of the ways of inoreasing a. child's rocabulary is through travel and through varied expariences such as excursions and activities. There is no doubt brt that these mobile chtldren have encountered the above.

Peamanship samples were analysed statistically through the use of the chi-square tochnique. Hore, again, was found no significant differences.

Characteristica, too, were analysed statistically by use of the ehi-square method. Transient children were found to be more weseurceful, more adaptable, more enthusiastic, less puncturl, less shy, and more persistent. There adsted a definite difference (at the If lerel of confidence) between the two groups in reference to broken homes. I significantly higher proportion of ahildren from broken homes came from the transient group.

Permanent children were found to be less resourceful, less adaptable, less enthusiastic, more puncturl, less persistent, and shyer. Fenter of this group came from broken homes.

I Teacher's Yanual, Iowa Tests of Basic Skdils, "Test V: Vocabulary", 1956, p. 23. 
Characteristics other than those listed in the previous puragraphs exhibited no significant differences.

The predominance of children from broken homes (1\% level of confidence) in the transient group brought forth the question as to diffarences in the characteristics of children from broken homes and nem-broken homes.

Iransient and permanent children were grouped togethor. A etatistical anelysis of these groups exhibited the children from broken homes to be: (1) less alert, (2) less creative, (3) less pepular, (4) less honest. Daficiencies occurred in attitude, varbal expreasion, and work habits in children from broken homes. Comparisons between chilldren from broken homes and nonbroken homes in the transient groups revealed the children from broken homes to be: (1) less popular, (2) less punctual, (3) less honest. Attitude and work habits also shored deficiencies.

Woteworthy, in these two comparisons, is the fact that the total number of children (transient and pernenent) when compared in groups from broken homes and non-broken homes, were less alert and less creative. However, transient children alone showed no significant differences in these characteristics.

Information pertaining to the repetition of a grade revealed no statistical difference between the two groups of children. This fact does not support Larsen's study which showed that children ahanging schools were four tines as likely to fail a grade. Service-connected children are from families of lower middle-class, 
Iddle class, and upper class status which may have a bearing on the ferrer ropetitions of grades with these children. In this impact area, teaching persomnel are accustomed to the transient child, know how to accept him, and aid him in his adjustment to a classroom dtuation. Personnel in areas where little mobility is present may lack experience with dealing with the mobile child.

Eraluation forms filled in by the teacher when analysed otratiotically revealed no significant difference in the participation of commanity activities between the transient and permanent children.

An analysis of children's reactions to changing schools were ainilar to those reported by Irane, Chapter II, page thirty-ae. These ahtldren, on the whole, were concerned about leaving ald friends and meeting new. They worried about whether or not they would be behind or ahead in their school work. Many felt that a change during the summer was preferable to one during the jear. Bren though worries were present, many of the children felt that ahanging schools was an advantage, and a challenge. There was little pportunity to become bored.

\section{Recommendations}

1.The problem of availability of records when a child enters a new school needs study. The delay encountered results in wisplecewent of the child in his proper grouping and a lack of information concerning the child's mental and physical health.

From the questionnaires received from areas where serviceconnected children reside, it was determined that the majority of these school systems send cumulative records only when requested by 
the mincipal of the new school. If these superintendents surveyed would take the initiative to establish a procedure in releasing the records, uniformity of procedure alght result. Oftentimes, the school to which the child is transferring is not known. A central agency, to which these records could be forwarded, at once, might alininate a waste of valuable time. Were this not possible, however, some specific action towards standardizing the procedure for sending records forward could alleviate the delay of days and oftentimes weeks in the acquiring of records by the new school.

2. Teachers in impact areas should be enlightened concerning the scholastic achievement and characteristics of the mobile child. They are above grade level scholastically, more resourcaful, more adaptable, more enthusiastic, and more persistent. If difficulties arise, the home enviroment needs study for these difficulties may be a result of the child coming from a broken home.

3. A need of some psychiatric halp for children specifLeally couling from broken homes would seem desirable. It was revealed that more transient childrea (1\% Ievel of corfidence) than parmanent ones come from broken homes. Problems arising from such a situation may be handled efficiently by a psychiatric social worker. Teachers and administrators must take valuable tine with ifficult problems for which they have little or no specific background or training. This has a tendency to detract from the time aletted for actual classroom instruction.

4. The need to maintain fewer chlldren in the classroom is apparent. In any area where great mobility is present, classes should not reach over twenty-1ive. If this occurs, a burden is 
pleced on the teacher. It does not contribute to the high-level of teaching expected in the schools. When mobility is present, more instructional groups within a classroom are inevitable and individual work is a "must".

5. Considerable thought regarding what may be dose for the permanent child must be undertaken. Is he being overshadowed by the transient child? What needs to be done for the permanent child so that he may become as resourcaful, adaptable, enthusiastic, and parsistent as the transient child. An opportunity to participate in more varied activities, travel, field trips, assemblies, and moeting people may be a means to this end. The questions arise as to the pessibility of a child in a fifth or sixth grade having more than one teacher. If the transient child adapts readily to a new ditaation, a change of teachers may aid the permanent child in his adaptability.

6. This study was based on a sample of children in the fourth through sixth grades. A study of children in the first three grades is recommended to discover whether the same likenesses and differences are discernable in the younger children. Such research might show different results from those show by this study of papils in the fourth, fifth, and sixth grades.

7. Another study of typical groups such as those utilized In this study is also recommended utilizing the abilities of the aildren. Intelligence was not a factor in this studs. It might be woll now to determine whether the transient ehildren with all their shifting from one school to another, are working up to their abilities or whether the permanent children are outstanding in this respect. 
8. A comparison of the scholastic achievement of children from broken homes and non-broken homes is also recormended.

9. A handbook of school policies presented to each parent, transient or permanent, would contribute to a better wnderstanding of the school, the persomel, the instructional program, the daily schedule, school facilities, and other policies and practices which affect the propil, his parents, and his school.

10. Services of parents, both transient and permanent, would contribute a sense of belonging to the school. Resources of parents, If used, would also be an incentive to the pupils of the parents. fny resources from the parents of permanent children should be a means for the stationary child to become more resourceful and less shy. Parents' participation in activities in the elementary school should be valuable in communication between the parent, teacher, and child.

It is the fervent hope of the writer that this humble, and no doubt, incomplete, analysis of school problems confroating transient pupils, together with suggested ideas for improvement, will help smooth out the rough spots and make adjustment easier so that their educational and all-around progress may be accelerated to a happy and successful conclusion for each individual pupil. 
Wickford Gramar School

99 Phillips Street

North Kingsterm, Rhode Island

June 10, 1959

Mr. John Smith

Superintendent of Schools

10 Main Street

Dallas, Texas

Dear Mr. Smith:

Lt the present tine I am enployed by the School Department of the Town of North Kingstorm. Quonset Maval Nir Station is in the aforementioned torn resulting in a transient school population.

I am writing a thesis pertaining to the characteristics of children belonging to this mobile school population. Is you are in a sinilar position, I would appreciate your remarks or coments (favorable or otherwise) concerning this transient school population. Are any special provlsions made for these children in jour commonity?

I would very much appreclate a reply to this letter. Thank you.

Very truly yours,

(Irs.) Gabriella H. Adams

lcting Principal of the

Wickford Gramar School 


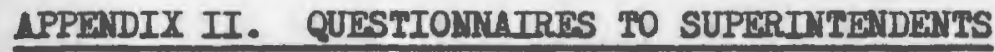

\section{QUESTIONALTRE TO SUPERTITENDERTS OF SCHOOLS \\ IN TOWAS OR CITIES IN WHICH ARMED FORCE \\ BASES ARE LOCATED AND III TOWNS AND CITIES NEAR SUCH BASES \\ (Please Underline Answers)}

1. Do you send a transeript with the child when he is transferring to another school?

\begin{tabular}{c|l} 
Yes No when requested & Remarks: \\
by principal &
\end{tabular}

2. Do you send a cumalative record of the child?

Yes No When requested |Remarks:

by principal

3. Are achievement test records sent? Yes No When requested
by principal

4. Do you send the I. Q. If this is avatlable?

Yes No when requested
by principal

5. Is the health recerd transferred to the new school?

Ies No When requested |Remarks: by principal

6. If the child has any specific difficulty, is this information transferred to the new school?

Yes No When requested |Remarks: by principal 
7. Do fou send a reading list of books read by the child?

Ies No When requested |Remarks: by principar

8. Ire confidential records sent to the new school?

Yes No when requested |Remarks:

by principal

9. Do your teachers have conferences with the parents of new students?

Always Sometimes If Necessary No | Remarks:

10. If a school sends for curulative record or confidential records of a student, are these records sent to the new school at once?

Ies No Sometimes | Remarks:

11. Do you have counseling to facilitate the adjustment of new students?

\begin{tabular}{ll|l} 
Yes No If Necessary & Remarks: \\
\hline
\end{tabular}

12. Do you encourage parents to visit school?

1lways If Mecessary Sometimes No |Remarks:

13. Are parents requested to register the students rather than the student coming alone?

Always If Mecessary Sometimes Ho Remarks: 
14. Is a school handbook presented to the parents when they register their children?

Yes Ho Remarks:

15. Do you have special classes to take care of differences, if any, in the transient children?

Ies Ho Remarks:

16. In your opinion, do you feel that there are any outstanding differences in these transient students as compared with the stable school population.

\begin{tabular}{ll|l} 
Yes Lo Iittle Great & Bemarks:
\end{tabular}

17. Do you have a remedial reading teacher?

\begin{tabular}{ll|l} 
Ies No In Some Schools & Remarks:
\end{tabular}

18. Are pre-school conferences held with new teachers to orient them to the situation of mobility in the classroam?
Yes No Sometimes
Remarks:

19. Are students placed in groups at a near achievement level? Yes No When Possible | Remarks:

20. Do you have a speech therapist?

\begin{tabular}{ll|l} 
Ies No In Some Schools & Remarks: \\
\hline
\end{tabular}

21. Do classes range froms
20 to 30 pupils
above 30
under 20 
22. Do you feel that reading would have progressed farther had these mobile children had no interruption in their learning?

Ies No Doubtful Remarks:

23. Do you feel that arithmetic would have progressed farther had these mobile children had no interruptions in their learning?

Yes No Doubtful Remarks:

24. Do you feel that the mobile children have rich experiences in history and geography?

Yes Ho Remarkes

25. Do you consider the work-study skills to be on a level with the stationary children?

Yes No Remarks:

26. Do you feel that these children have difficulty in adjusting to their new environment?
Ies Mo Iittle Much
Remarks :

27. Is a foreign language taught in the elementary schools?

Yes No

Remarks:

28. If a foreign language is taught, are the mobile children entering at various times of the year included in this program?

\begin{tabular}{l|l|l} 
Yes No Sometimes & Remarks:
\end{tabular} 
APPENDIX III. WRITING SAMPLES TRANSIENT CHILDREN GRADE FOUR

all of my old pals Mut of course when move to other place o da lays make fiends.

$$
\text { Rating - } 1
$$

When t come to a new school tim allure a fit scared at frit but of ter a while it tern ed out to be all resht.

Bating - 2

New friends 'are fun to play with. an her. slay. games ant Rating - 3

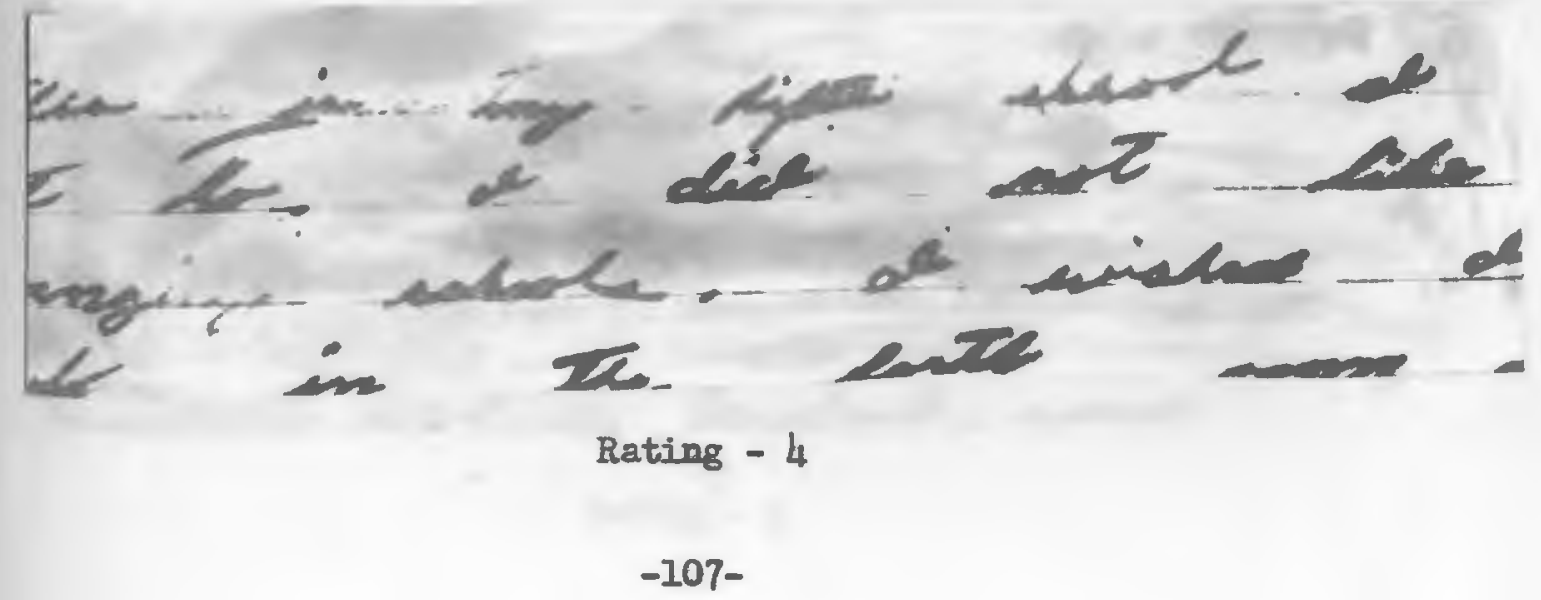


$-108-$

PERMANENT CHETIDRINI GRADE FOUR

lame is a nice month for playing, With all the trees swaying, When the breezes go slowly by, Coming herm the light blum she.

Rating - 1

1 thought it was a little-schrol. But it was not, it was a big as dxchool.l herat it 2 ads anodes. Rating - 2

June is ce happy time of the year the Beaches orem school is ort Curry bode. has been in tune. Rating - 3

Dune in thrice month with ale 26 bine singly and If tram is get aid hit of dell mat ply

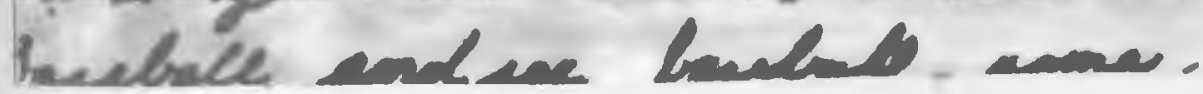

Rating - 4 
$-109-$

TRANSIENT CHILDREN GRADE FIVE

I theme it is intervition to gar from one school to another to meet new friends tor not all school d are be -

Rating - 1

d dan't like to mover fro u school to another beck have to leave my indus, and s mus teacher

Rating -2

The to change school because of lie

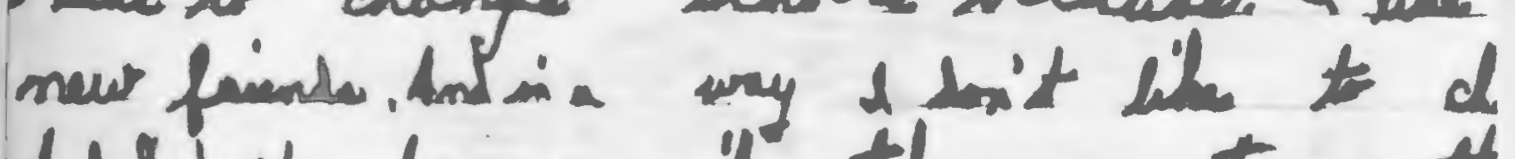
bald doit become it the me tor a th

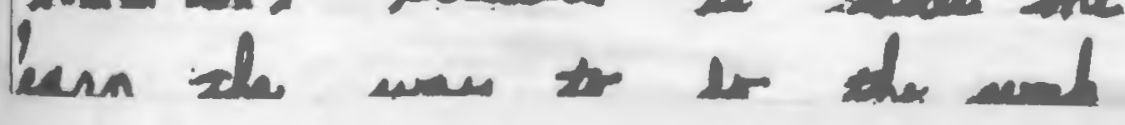

Rating - 3

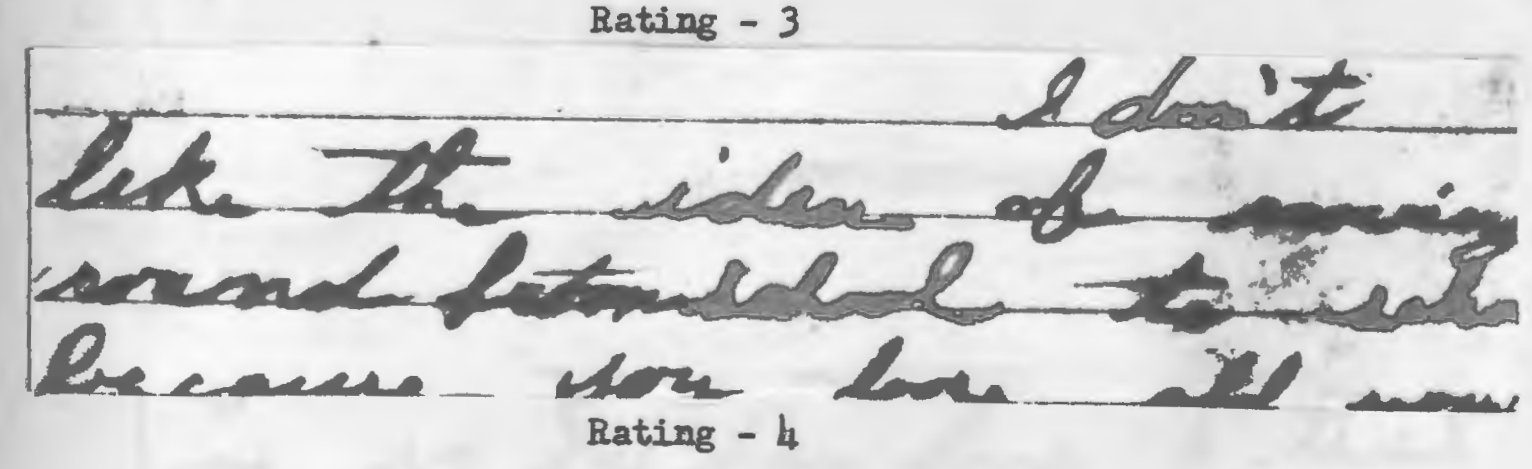


$-110-$

PERMANENT CHILDREN GRADE FIVE

My impression of changing from school to another is that: grade higher than the others. Dis like the teaches alter 2

Bating - I

like to move from one place to and want to gut a good education. re e move from chad to school 1 th bu bes a lat of and educations that

Rating - 2

I lib te chang scheali, because to s pred of going the is me stow ow er pres again, ot is fun going thoth

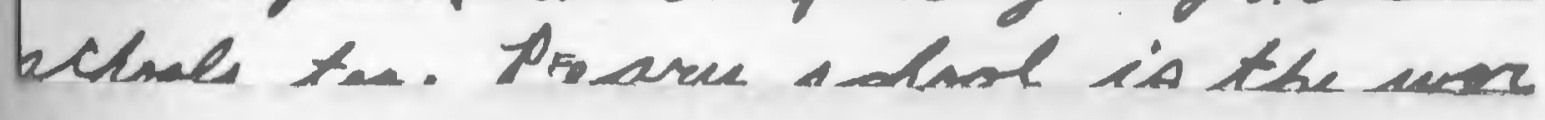
Rating - 3

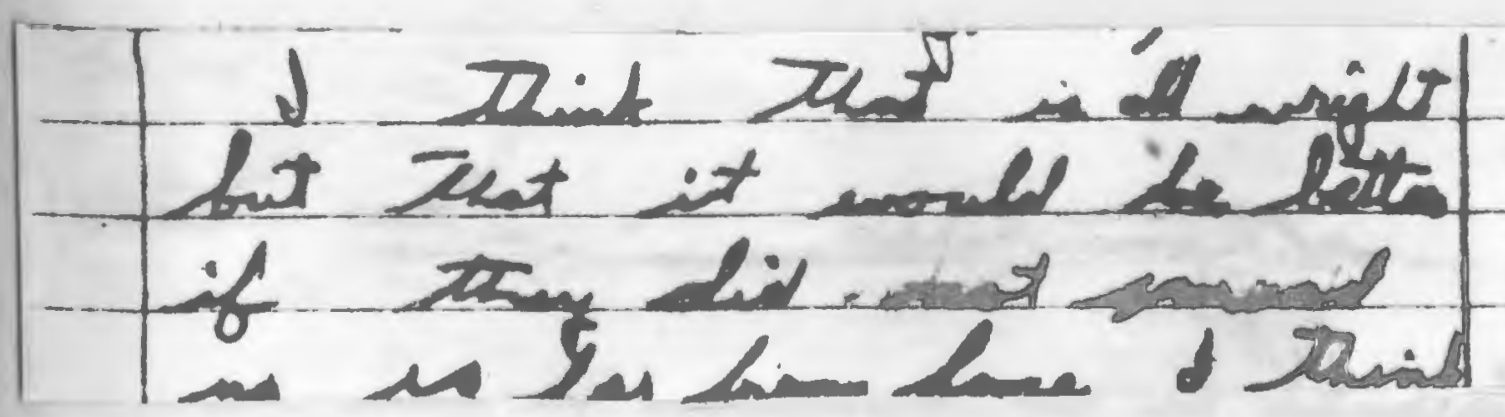

Rating - 4 
-111-

TRANSIENT CHILDREN GRADE SIX

changing schools is a rory exciting and thrilling experience. at though it in wu s hard to part with all your friends; you en iou lontima loswart and thimbina of Rating - 1

1 don't like changing frow owners and th. When you change sc hols.

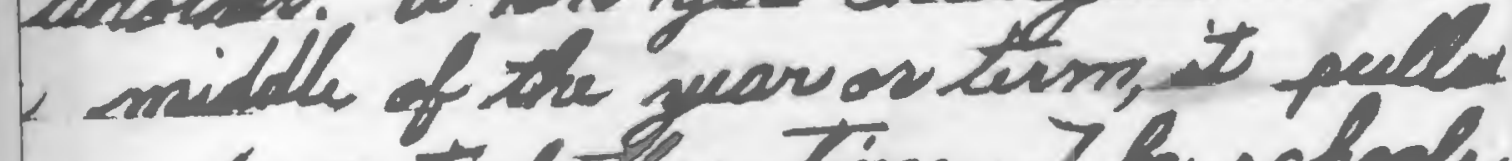

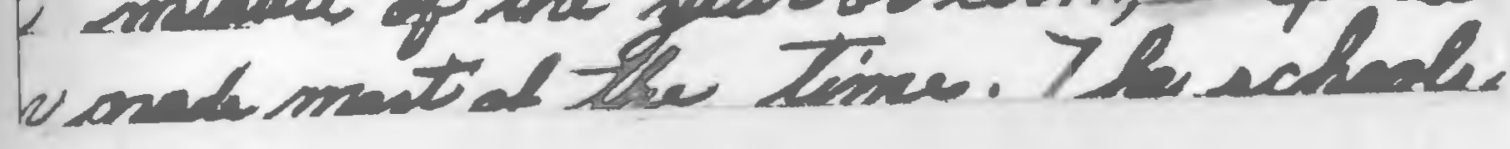
Rating - 2

When \& first cane to the this arles 1 aliment cred, list then \& begin to you

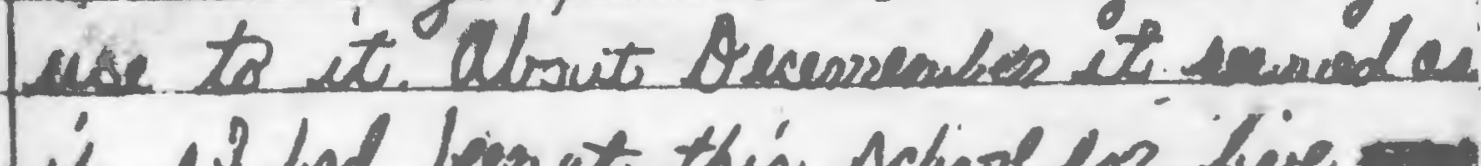

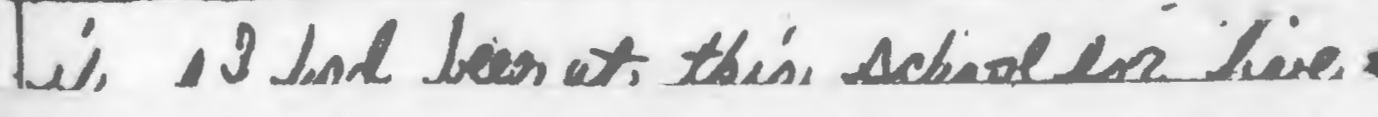
Rating - 3

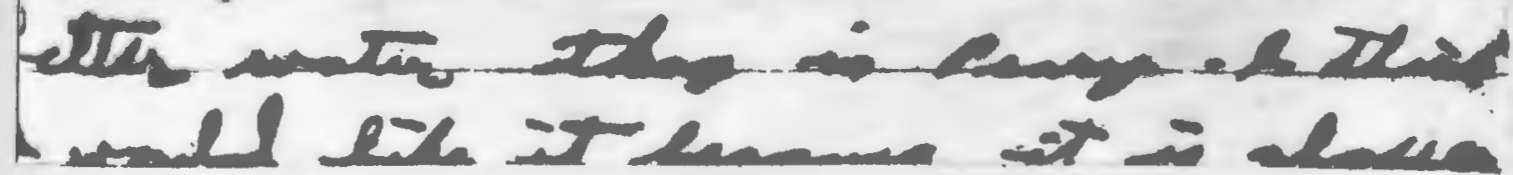

Rating -4 
$-112-$

PERMANENT CHILDREN GRADE SIX

Changing schools doesmits have ran sticulas effect upon me the problems. st t always an nays mes is getting aces

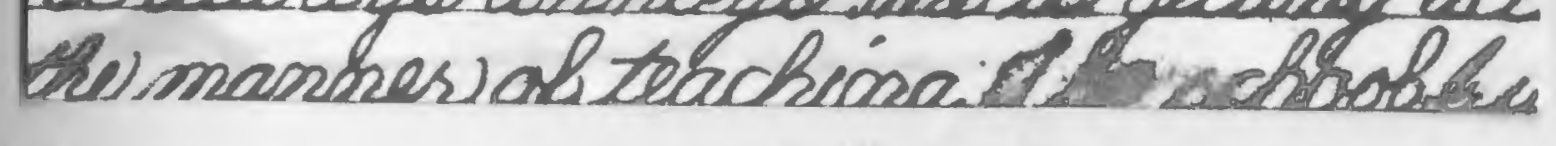
Rating - 1

2. think moving from ached to ocher during the

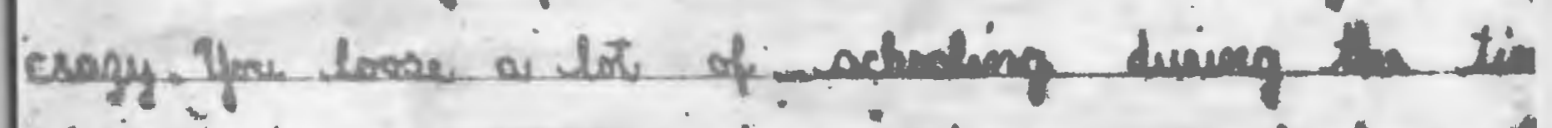

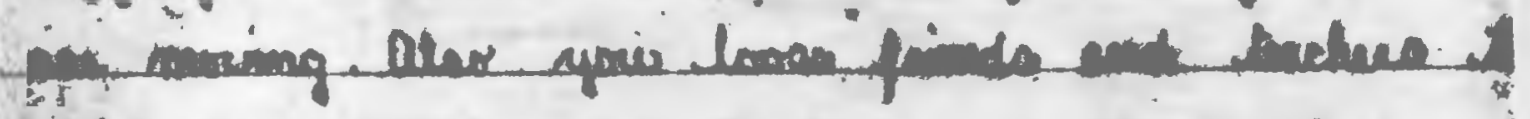

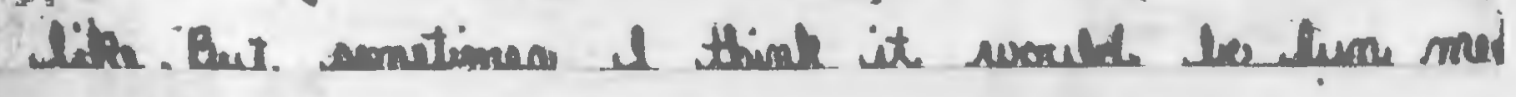
Rating - 2

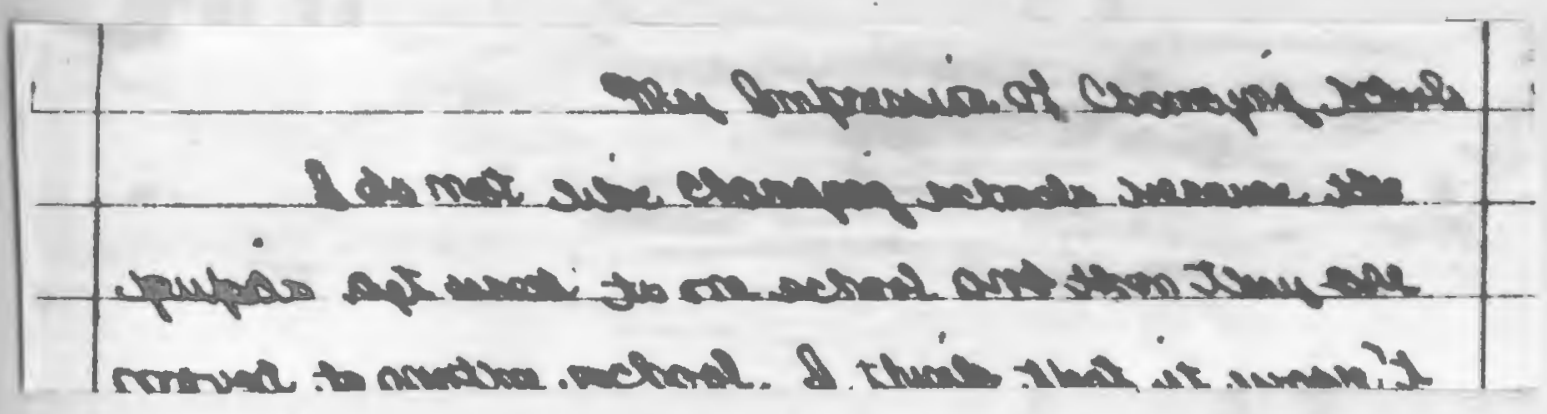

Rating - 3

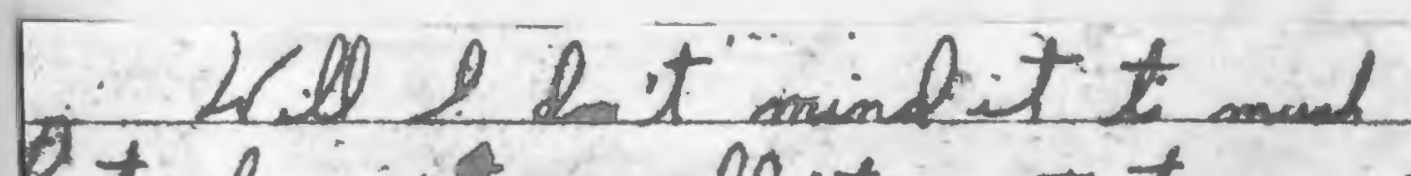

int $2-\frac{1}{B}$ molly mat $t$ max $t$

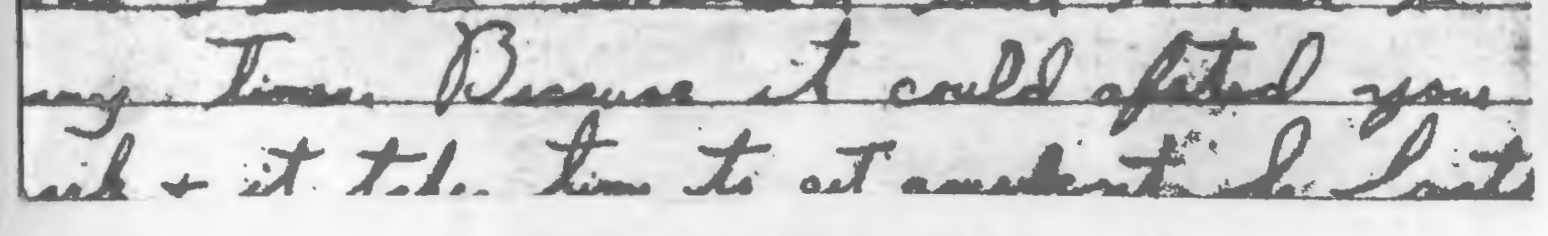

Rating - 4 
Iowa Tests of Basic Skills

\section{Reading Comprehension - Grade Four}

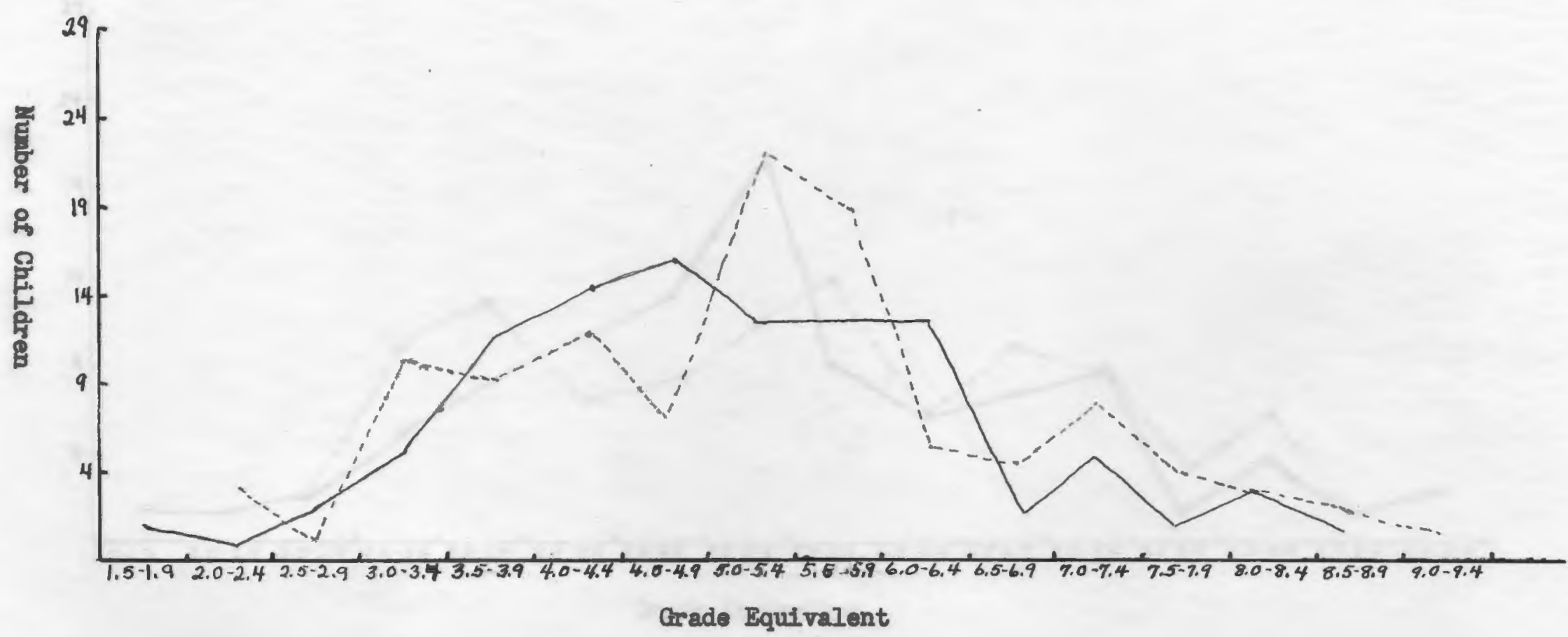

Permanent Children

-. Transient Children 
Iowa Tests of Bagic Skdils

Spelling - Crade Four

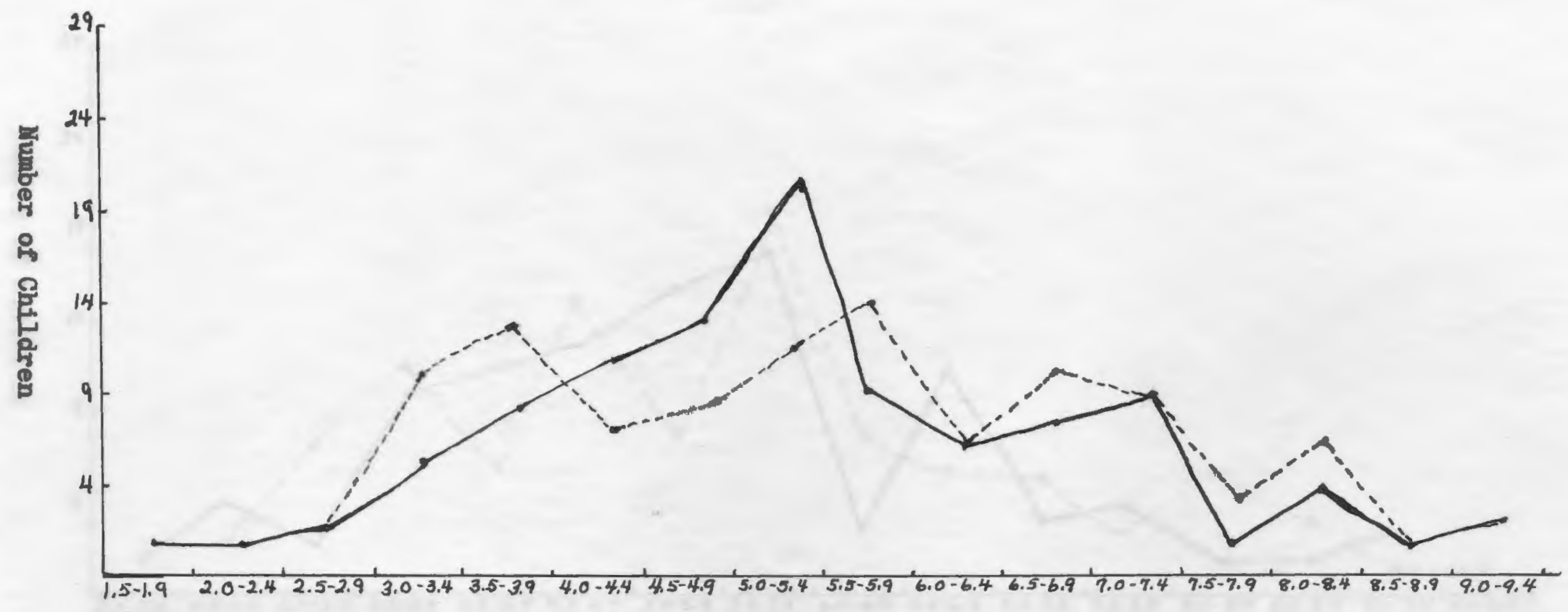

Grade Equivalent

Permanent Chtldren

-. Tranelent Children 


\section{Iowa Tests of Basto Sidills}

\section{Capitalization - Grade Four}

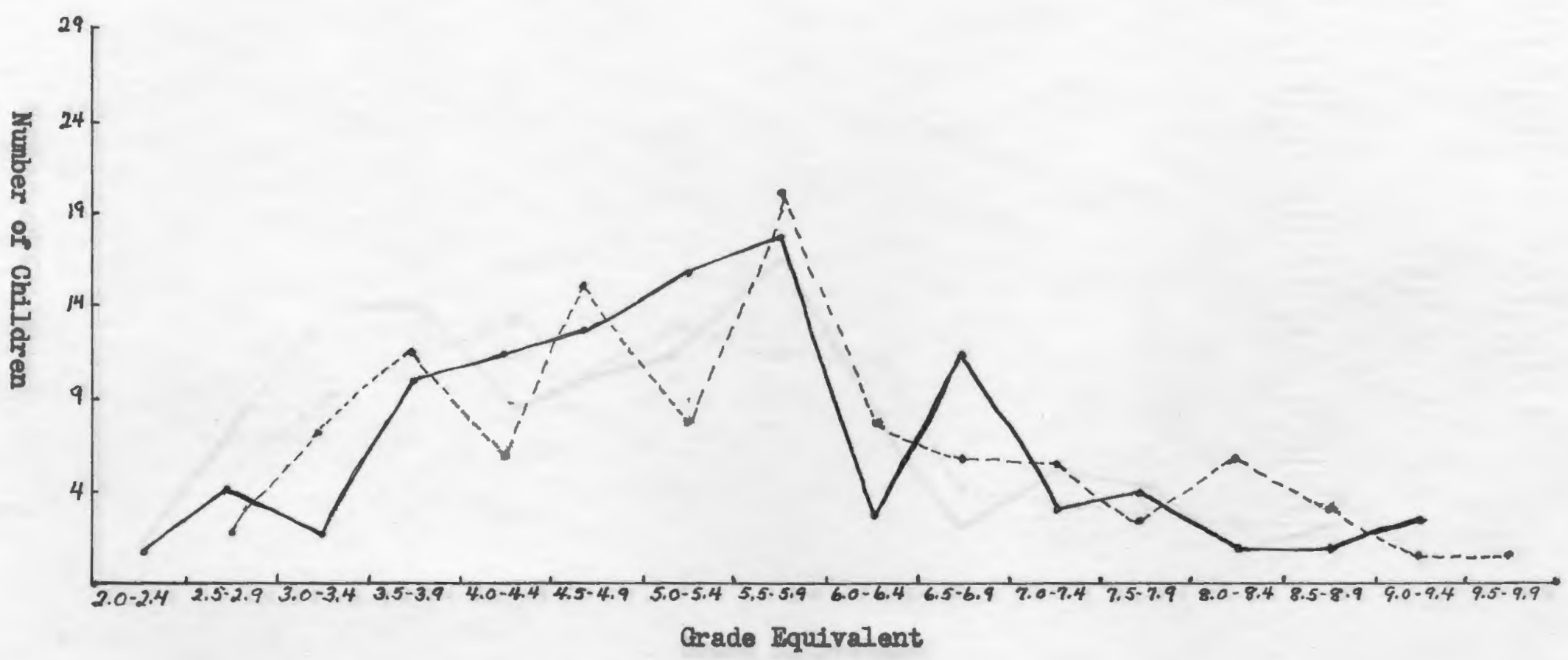

_ Permanent Children

- . Transient Chtldren 
Iowa Tests of Basic Skill.

\section{Punctuation - Grade Four}

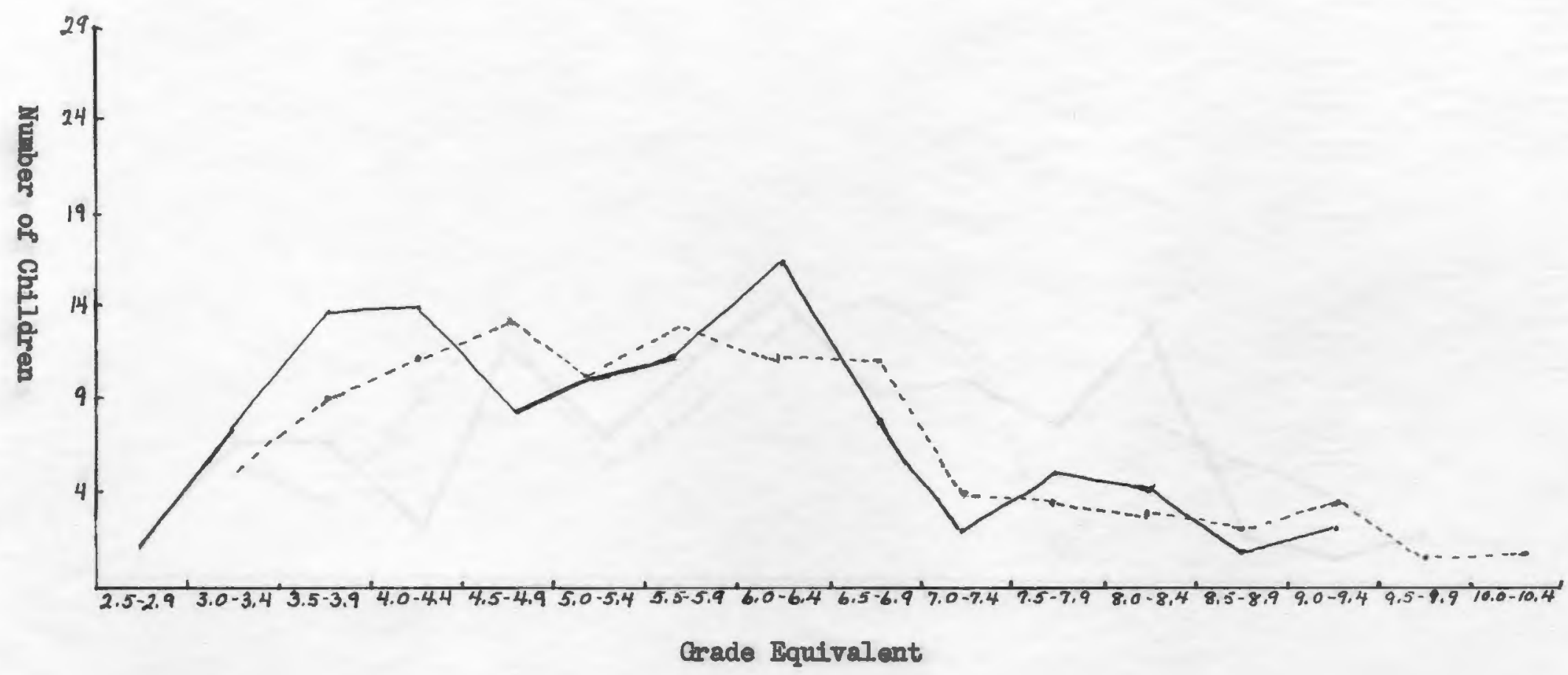

- Permanent Children

-. Transient Children 
Iown Tests of Basic Skills

\section{Language Usage - Grade Four}

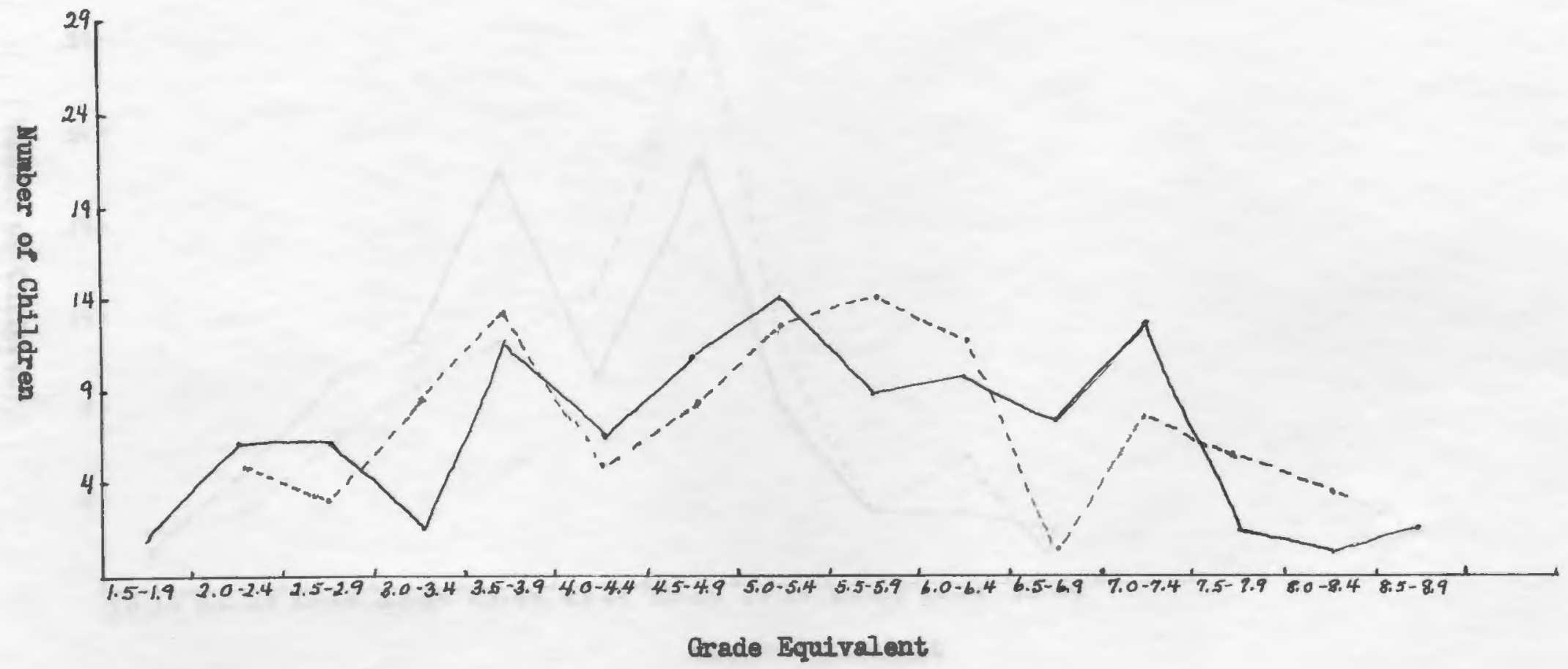
Permanent Childrea

.. Transient Children 
Iowa Tests of Basic Skills

Map Reading - Grade Four

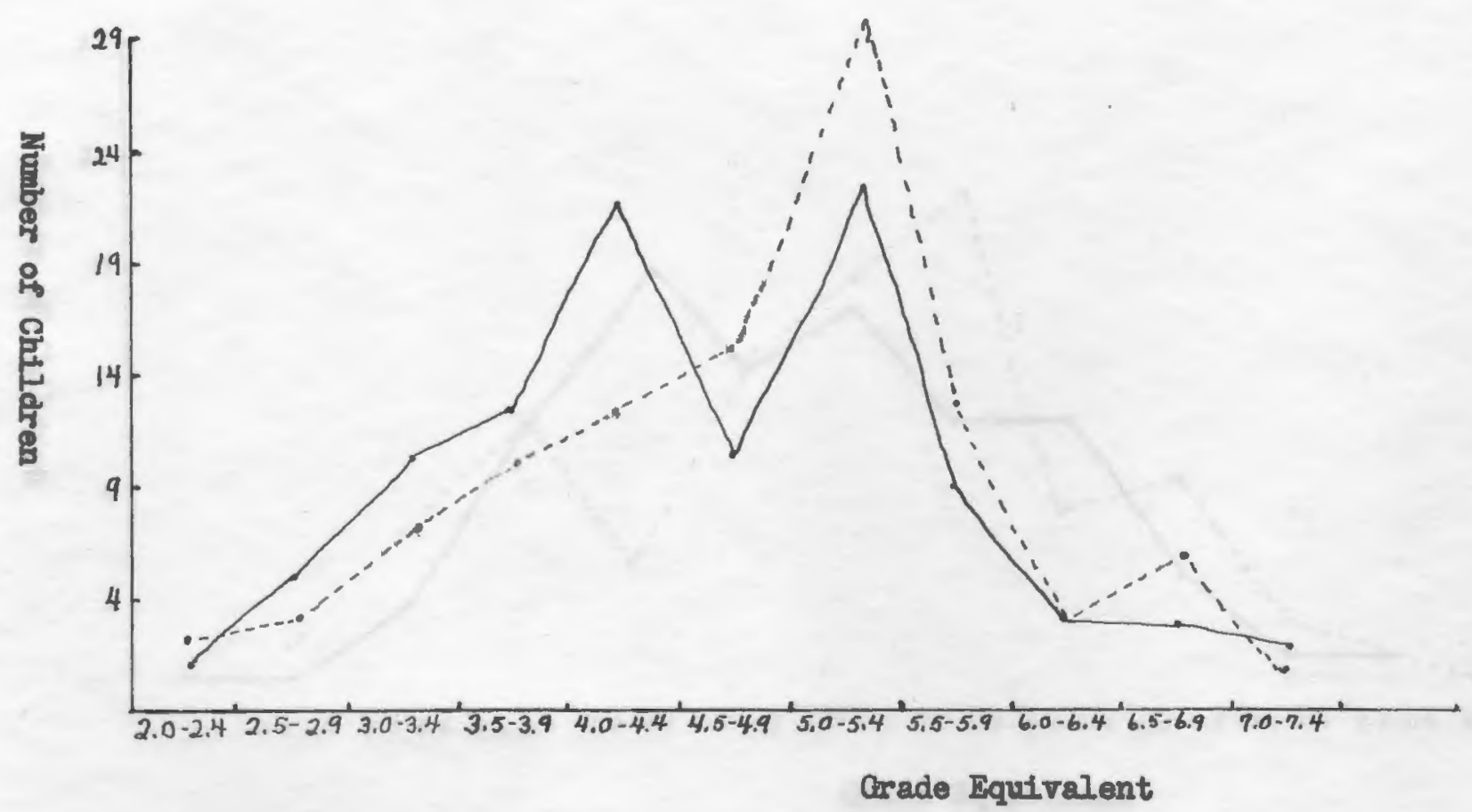

__ Permanent Children

-. Transient Children 


\section{Iowa Tests of Basfc Skills}

\section{Knowledge and Use of Reference Material - Grade Four}

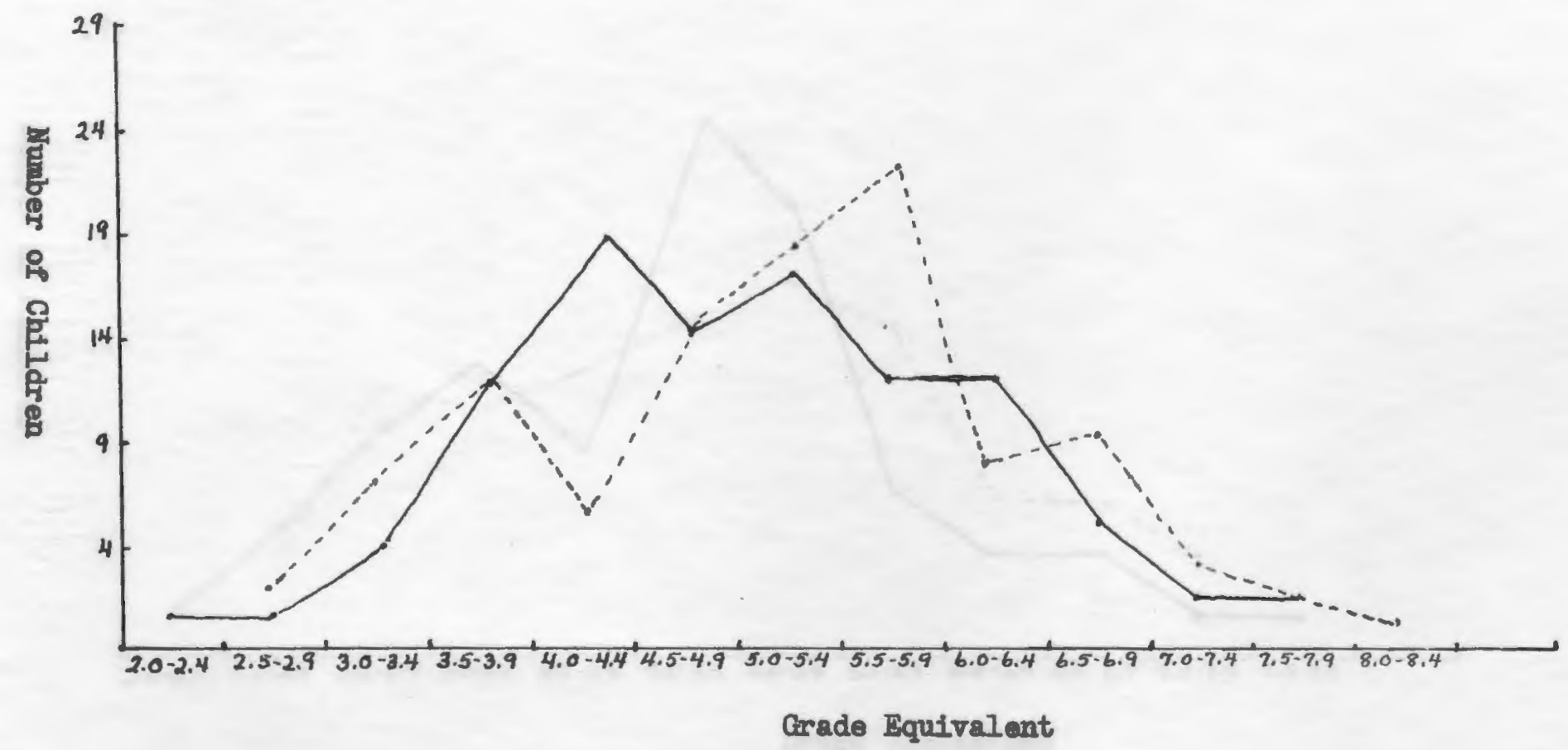

_ Permanent Children

-.. Transiant Children 
Iowa Tests of Basic Skdlls

Reading Craphs and Tables - Grade Four

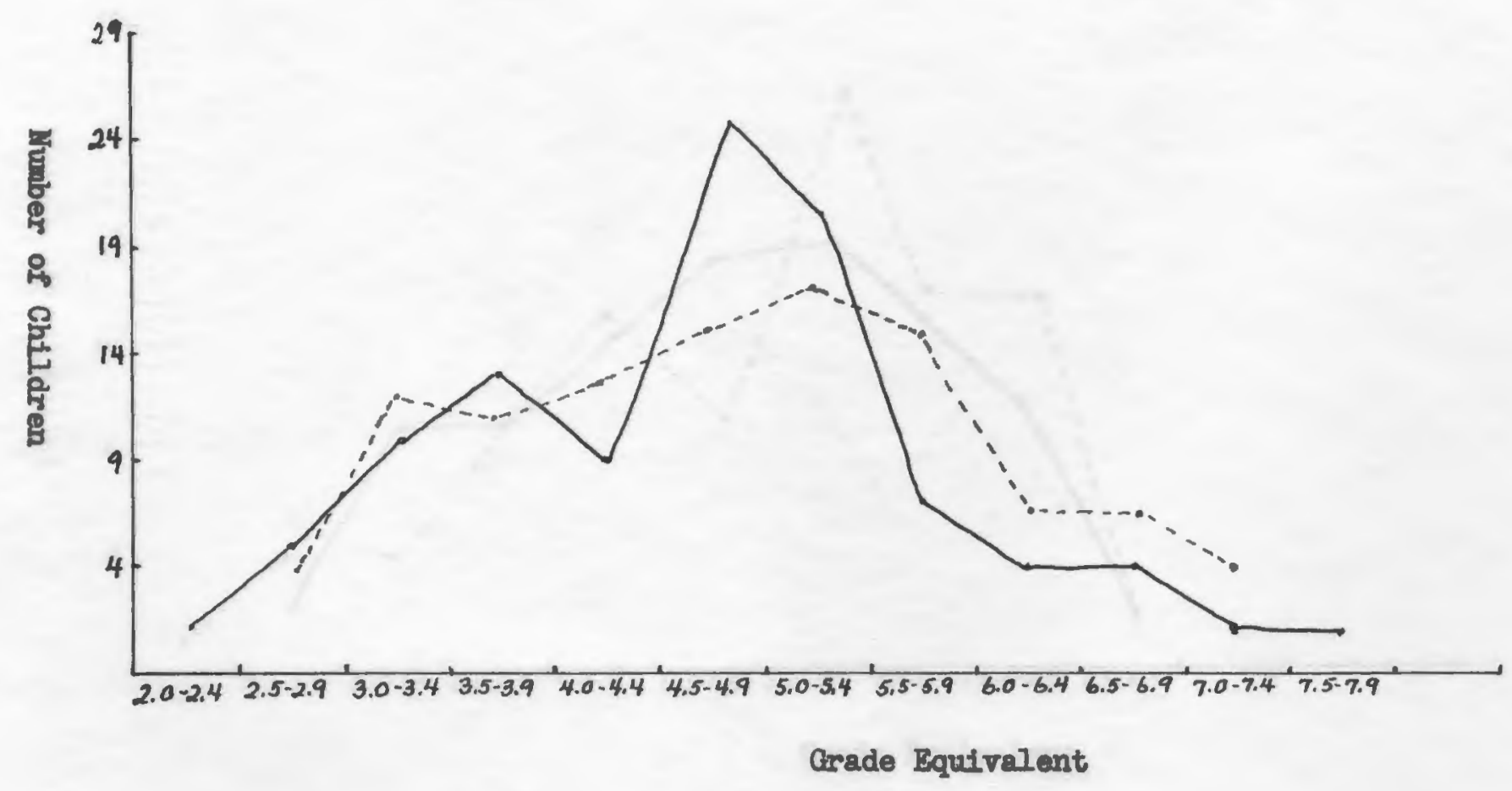

Permanent Children

..... Transient Children 
Iowe Tests of Besic Skills

\section{Arithmetic Conoepts - Crade Four}

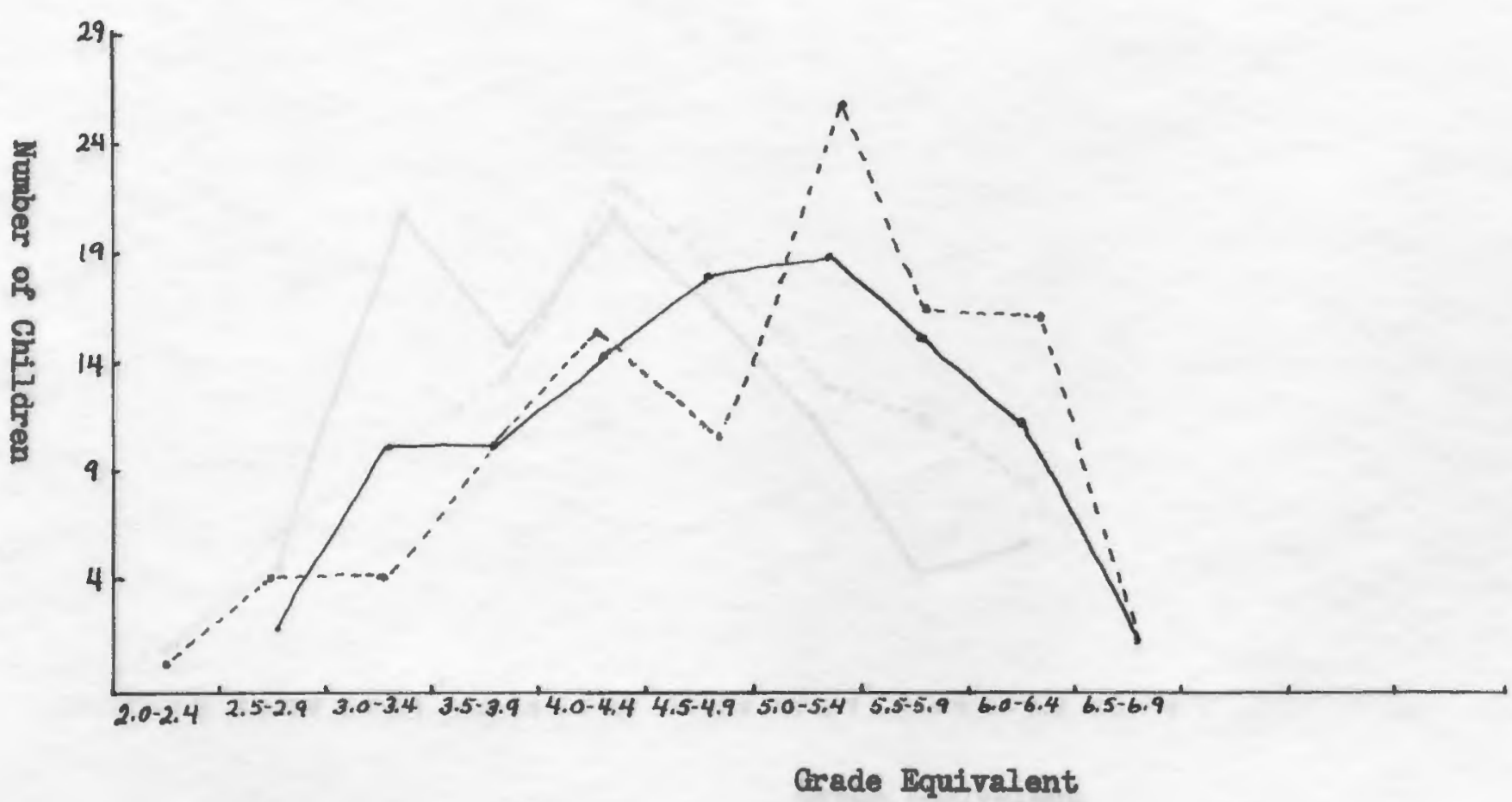

Permanent Children

- . Transient Children 
Iowa Tests of Basic SkJlls

Arithmetic Problem Solving - Grade Four

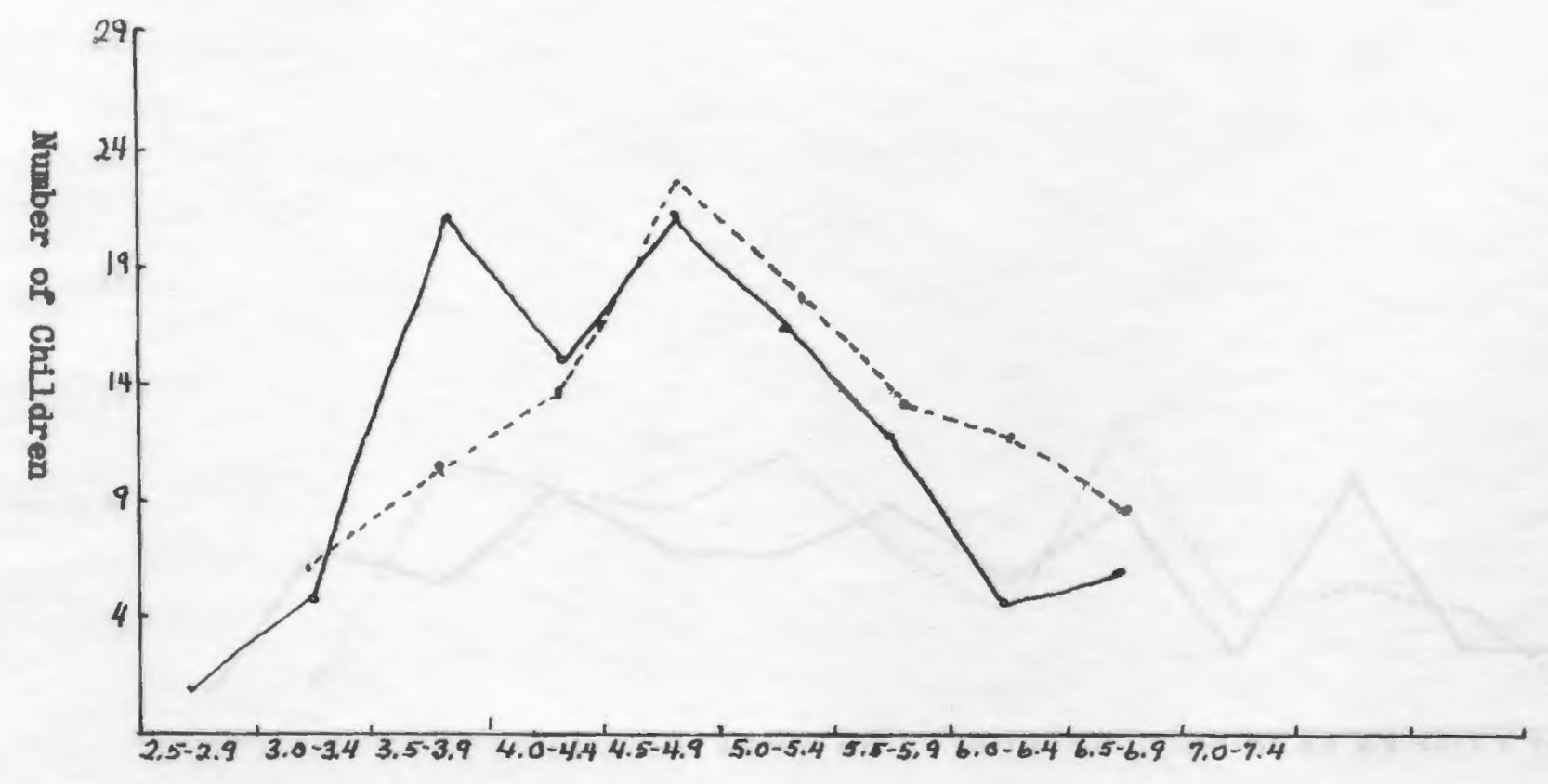

Grade Equitralent

Permanent Children

- . Transient Children 
Iowa Tests of Basic Skills

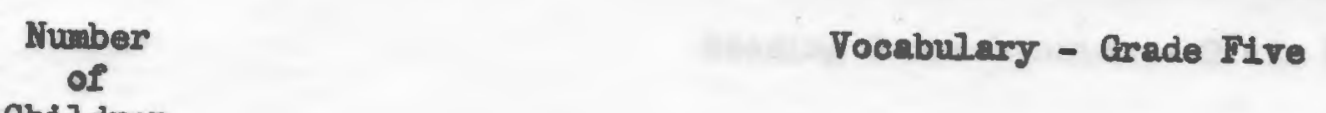

Children

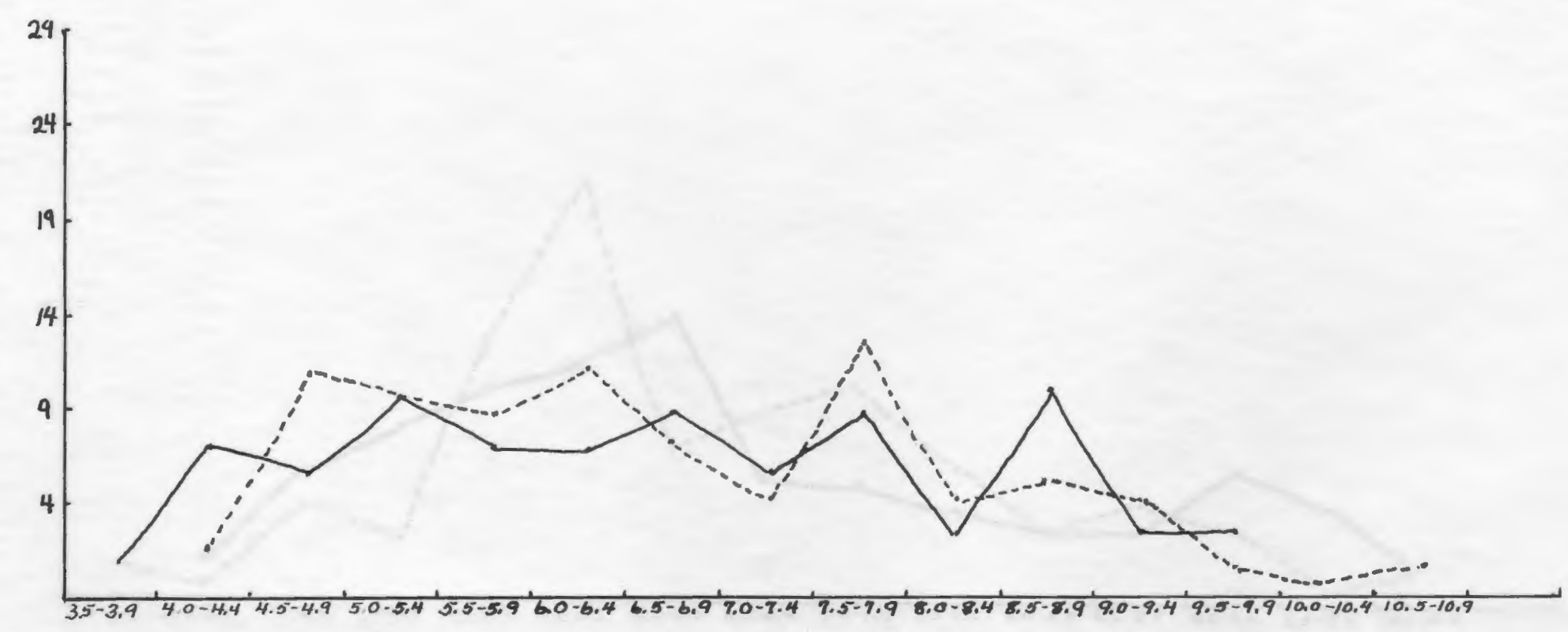

Grade Equivalent

_ Permanent Children

-.. Tranaient Children 
Iowa Tests of Basic Skells

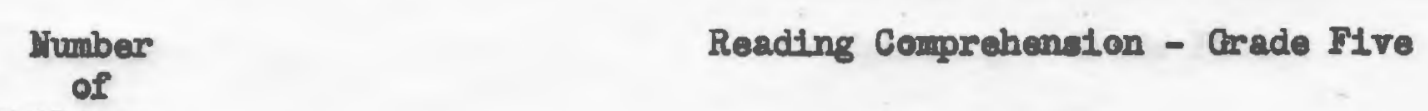

Ghildren

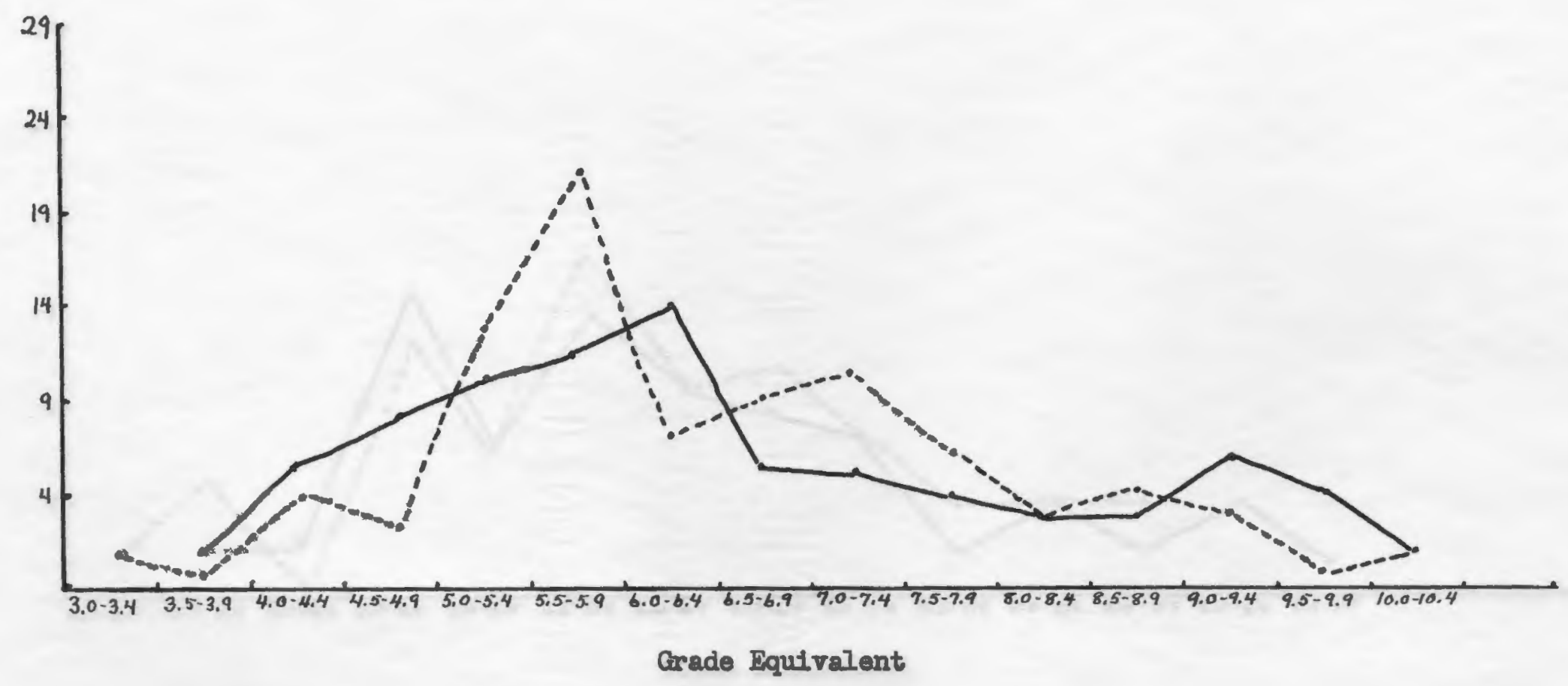

- Permanant Children

-. Iraneient Children 


\section{Iowa Tests of Basic Skills}

Number

Spelling - Crade Mive

Children

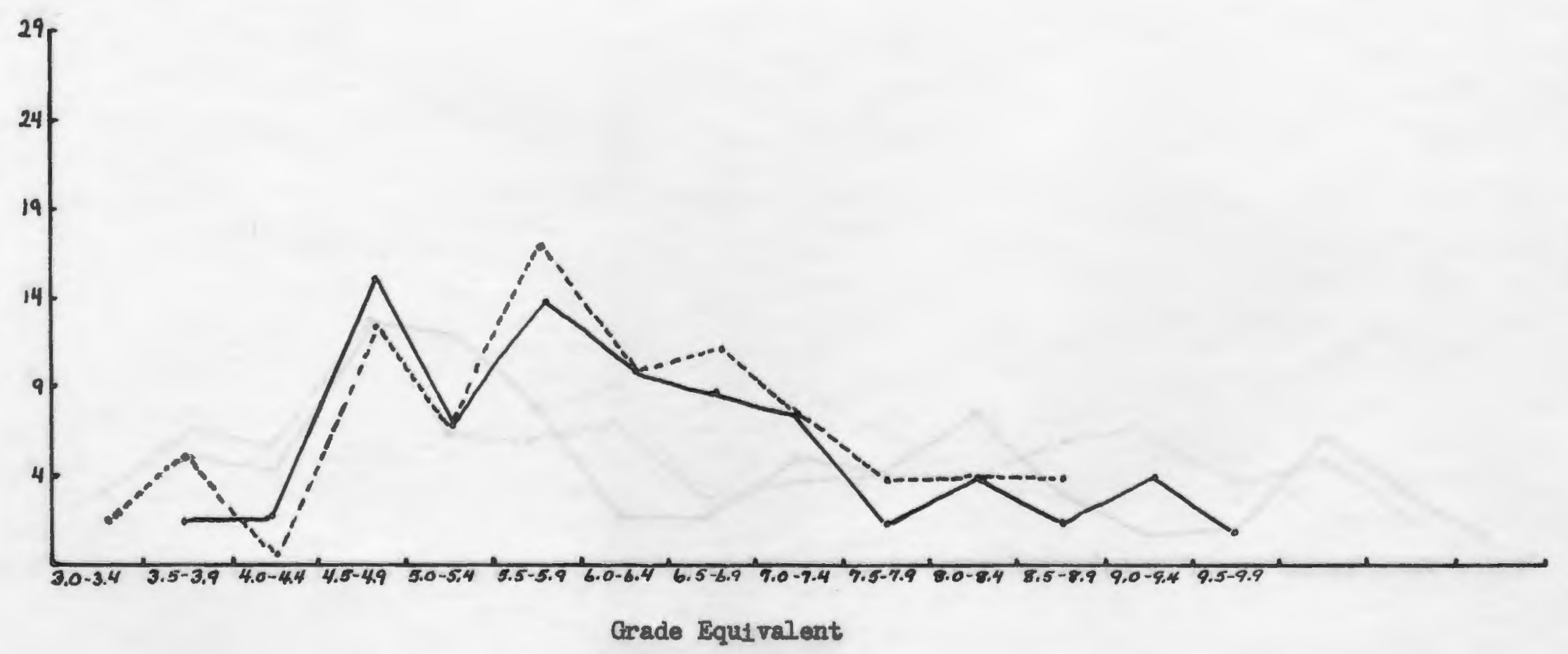

- Permanent Childran

- . Transient Children 
Iorra Tests of Basic Sidlls

Number Capitailastion - Crade Five

Children

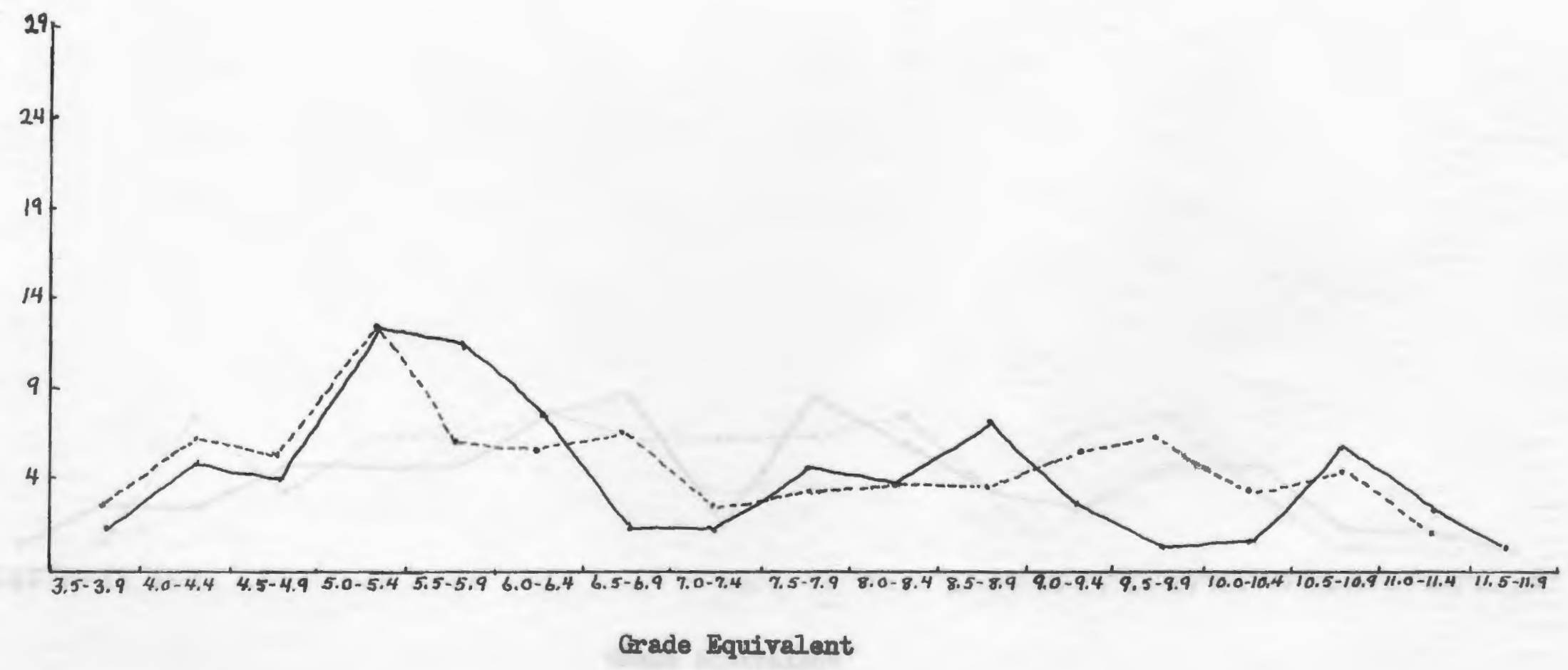

- Permanent Children

- . Transient Children 
Iowr Tests of Basic Skeflls

Number
of
Children

Punctuation - Crade Five

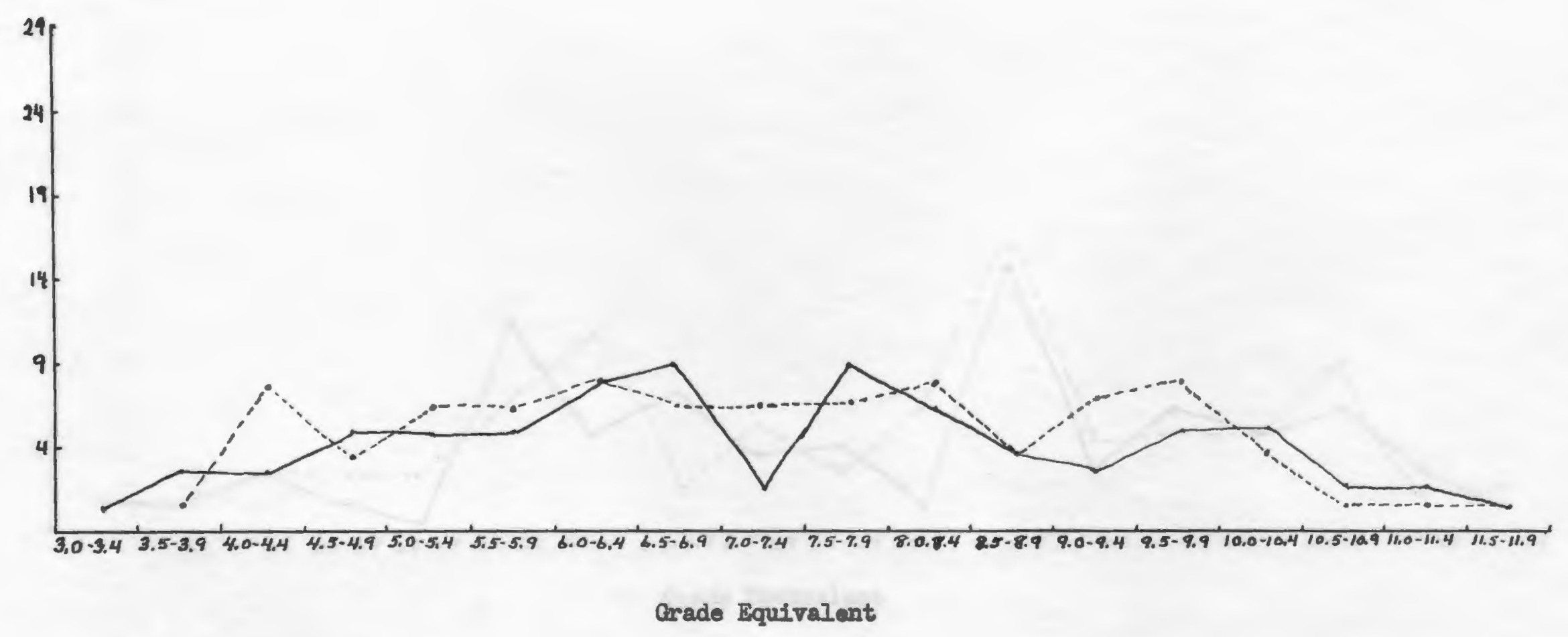

Permanent Children

... Transient Chtldren 


\section{Iowa Tests of Bagic Skilis}

Numiber

Language Usage - Crade Mive

of

Children

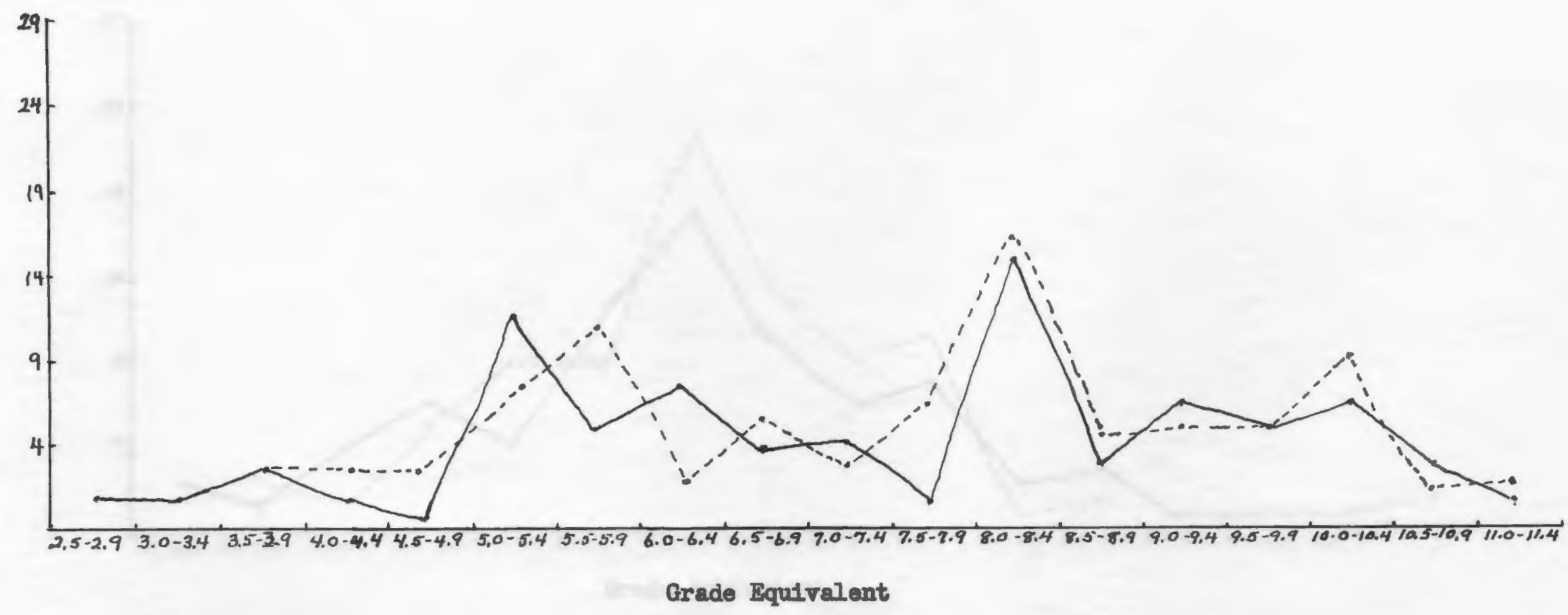

Permanent Children

-. Transient Childran 
Iowa Tests of Basic Skdils

Number

Map Reading - Grade Five

of

Children

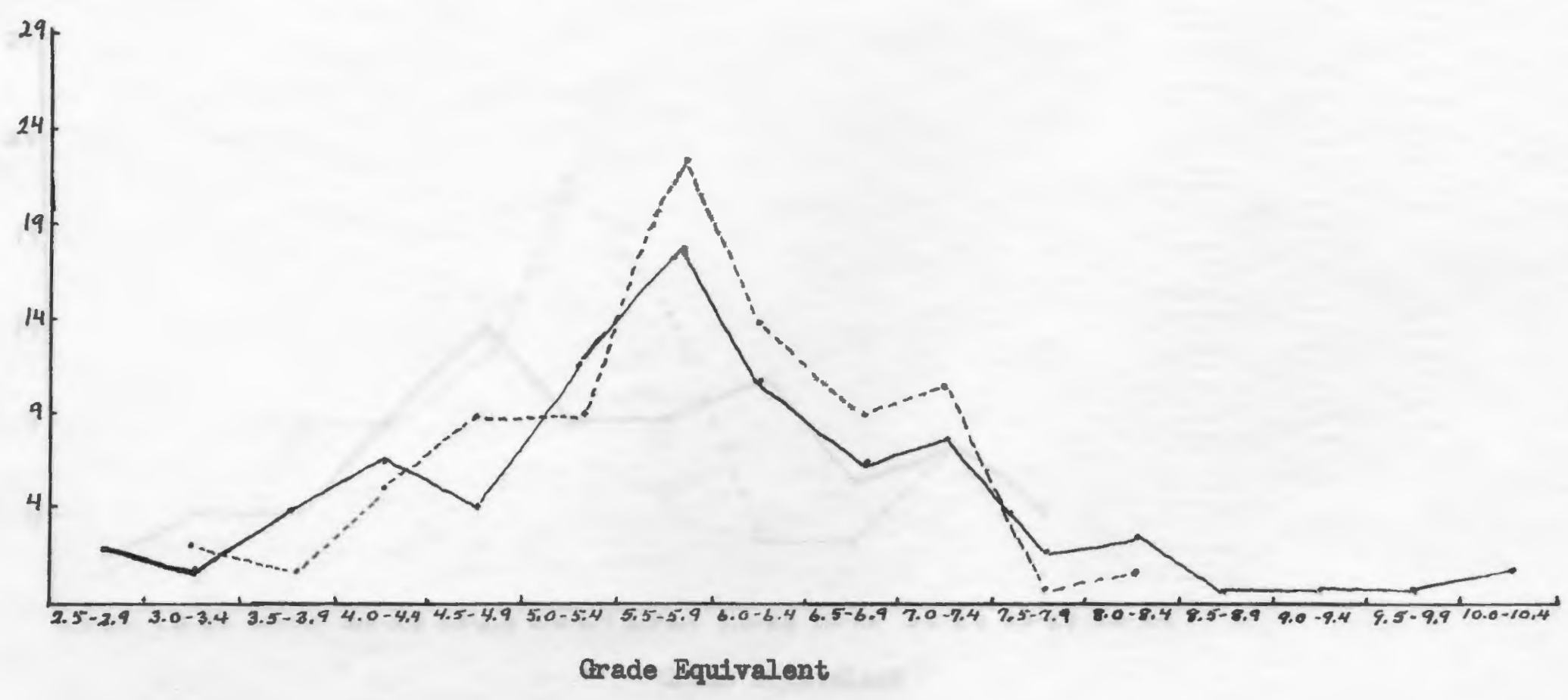

- Permanent Children

- . Transient Children 
Iora Teats of Basic Skills

Number of Knowledge and Use of Reference Material - Crade Five

Children

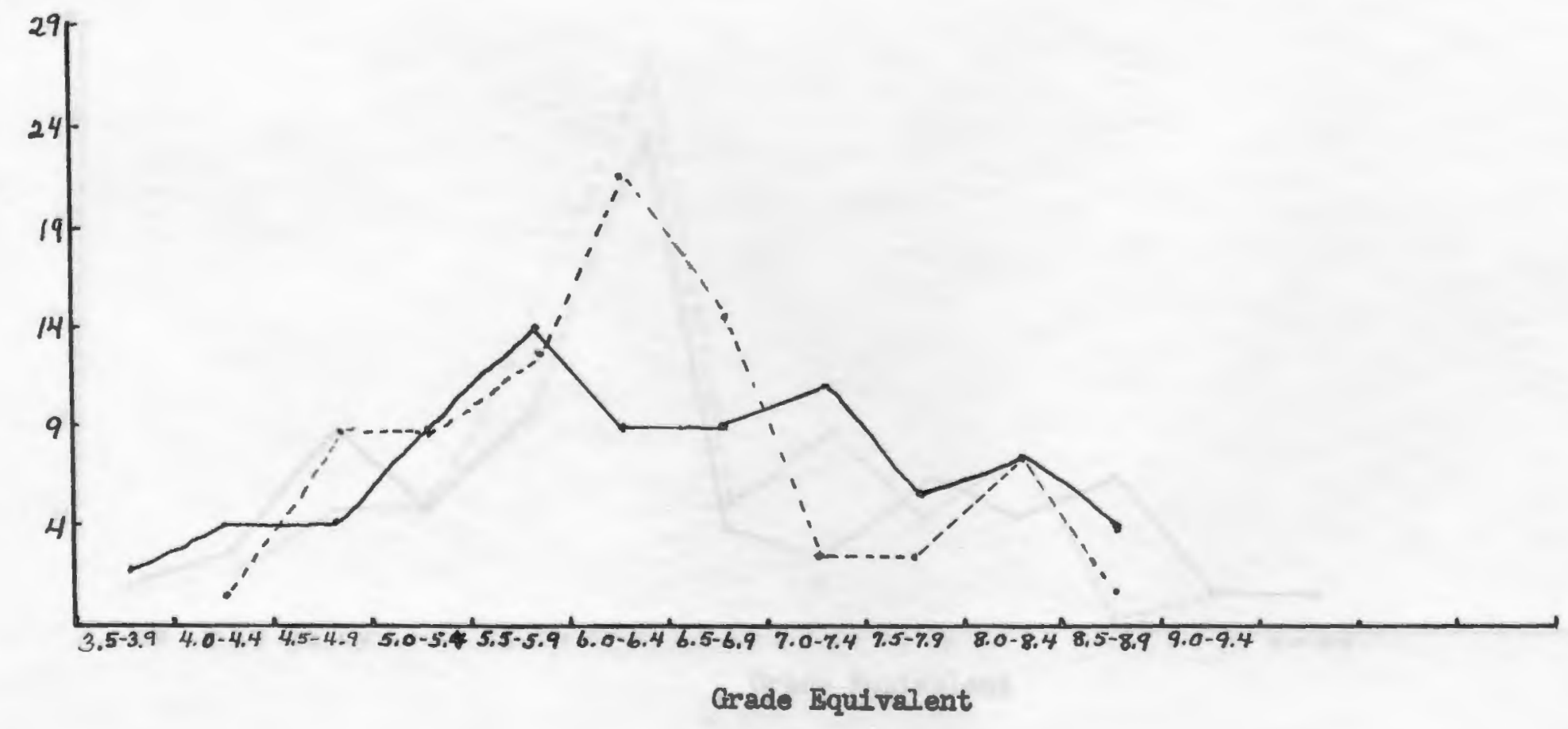

Permanent Children

- . Transient Chilidren 
Iorra Tests of Basic Skilis

Number

of

Children

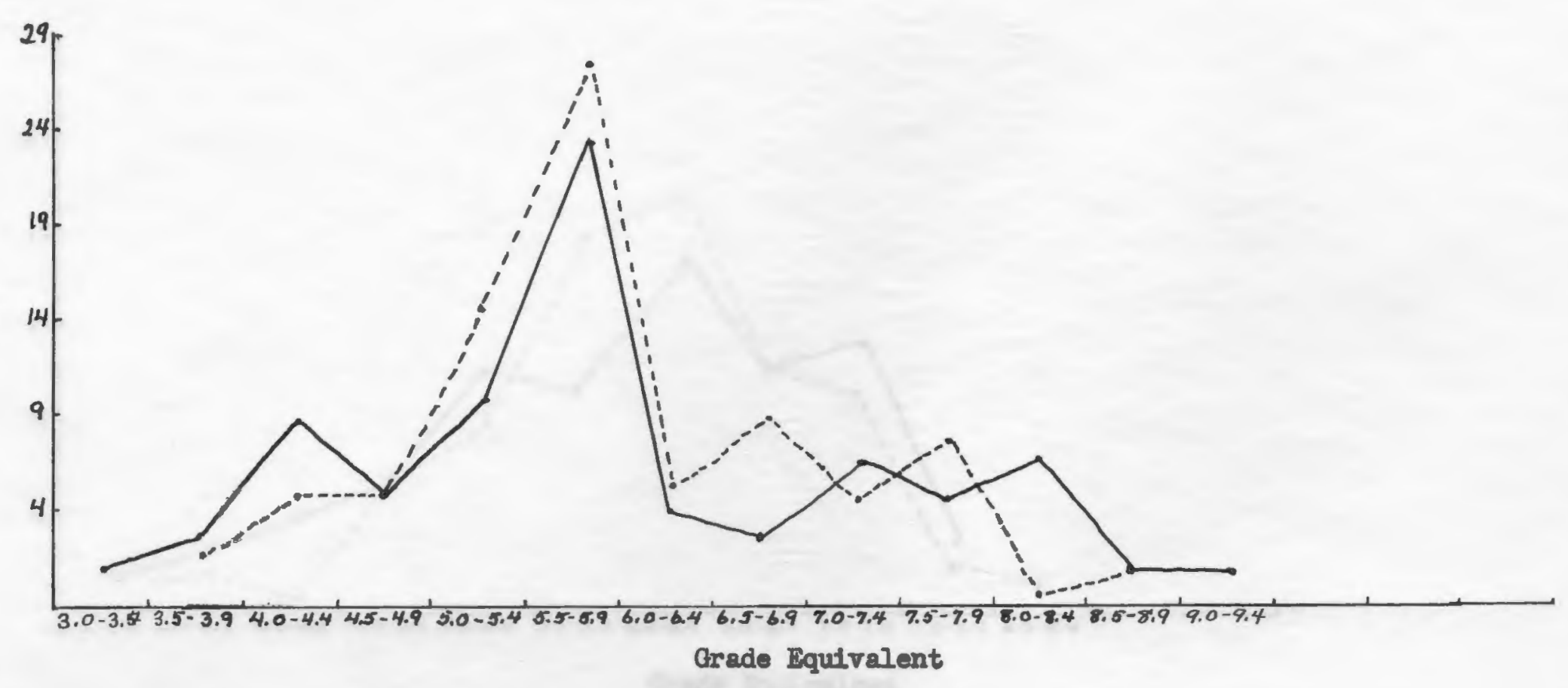

Permanent Children

- . Transient Children 
Iora Tests of Besic SkdIls

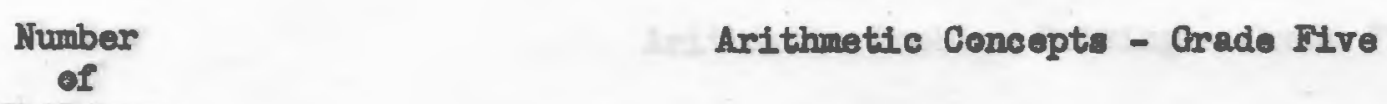

Chilldren

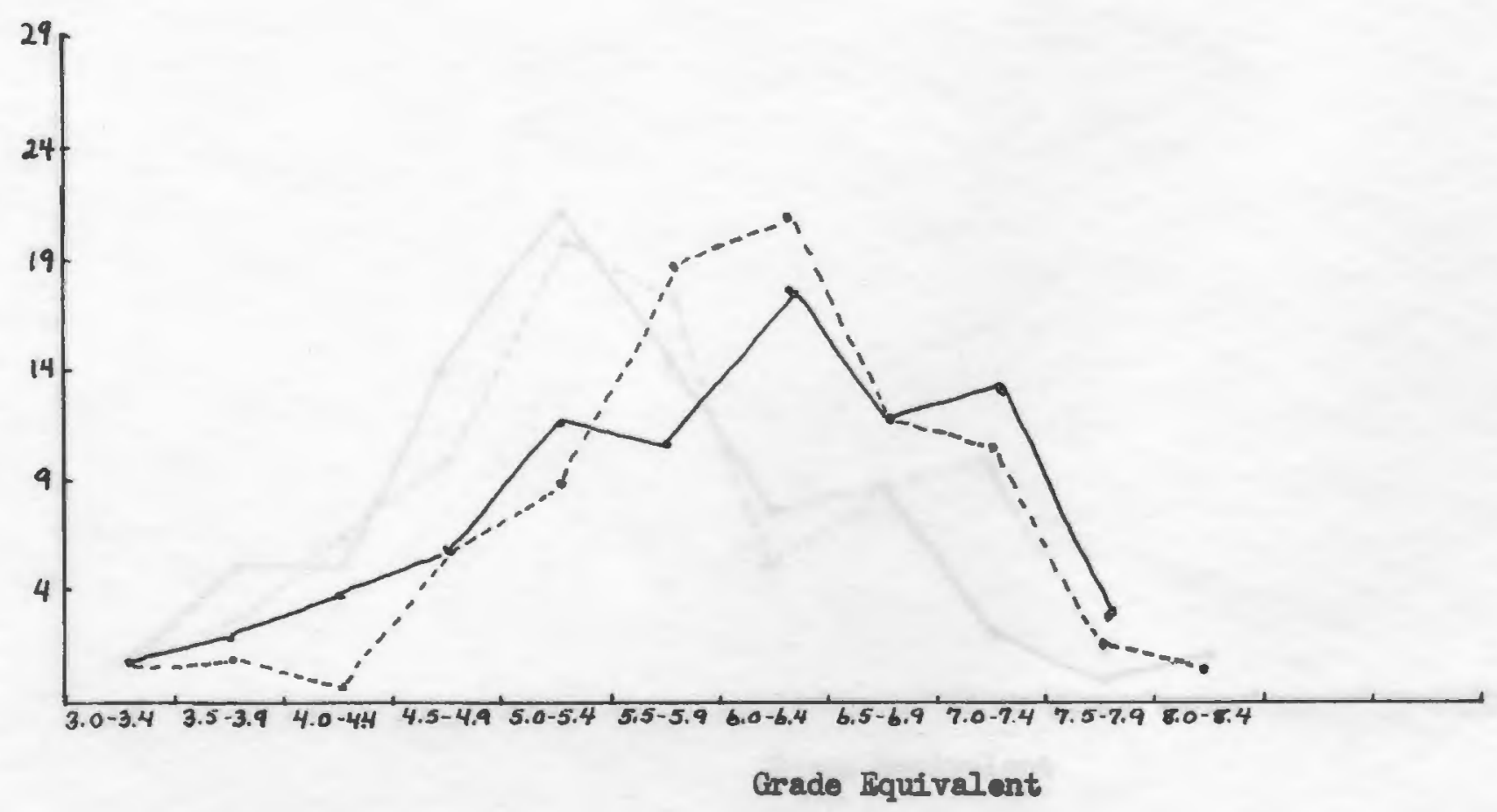

… Permanent Children

- . Transient Children 


\section{Iowa Tests of Basic Skills}

Number

of

Arithmetio Problem Solving - Crade Five

Children

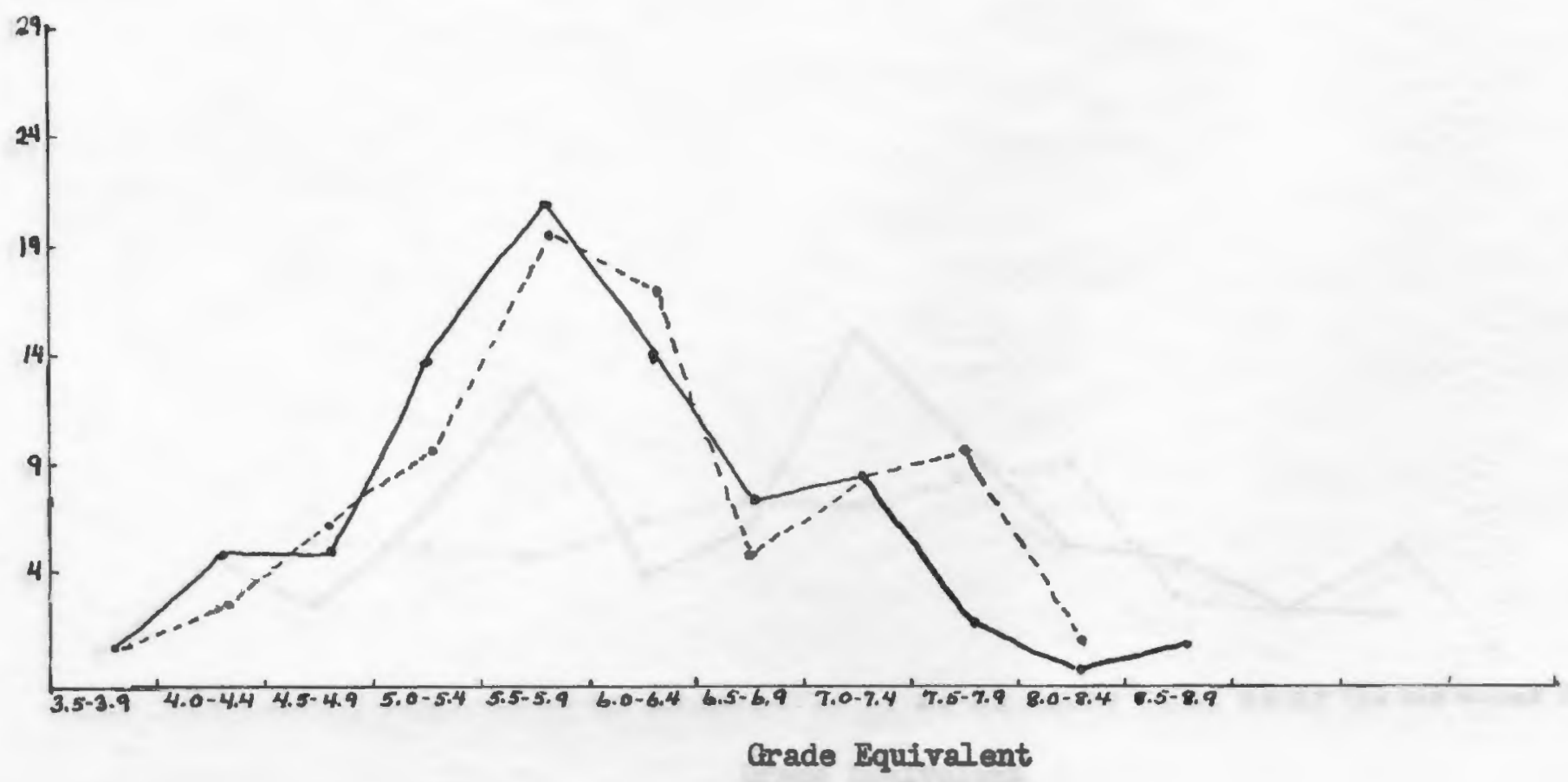

Permanent Children

-.. Trensient Children 
Iowr Tests of Basic Skills

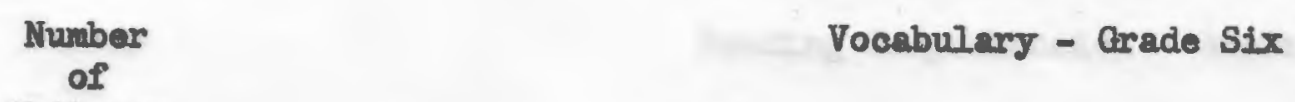

Children

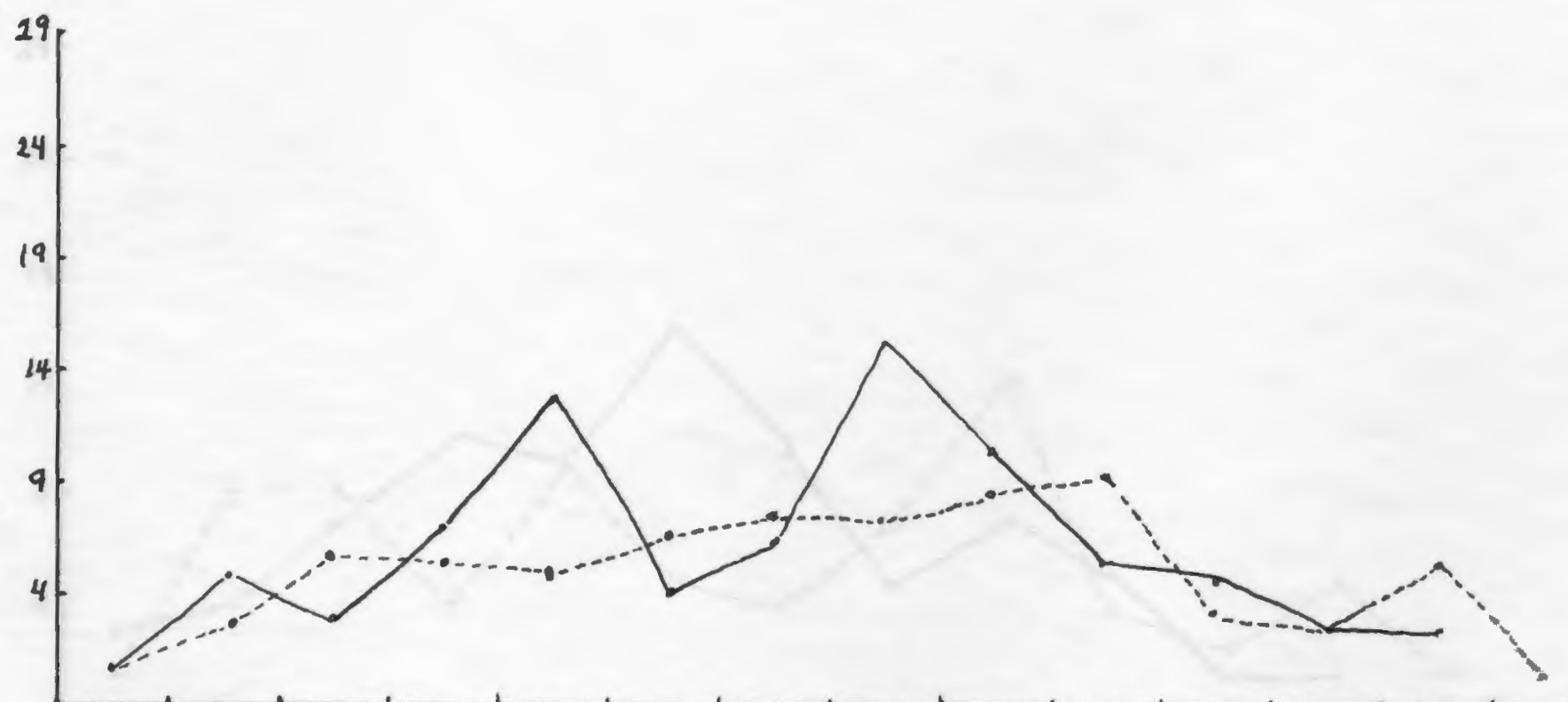

Grade Equivalont

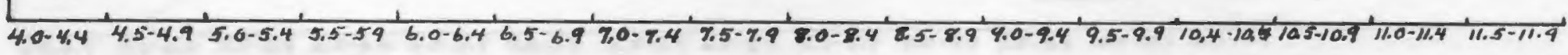

_- Permanent

- . Iransient 
Iowa Tests of Baste Skille

Numbar

of

Reading Comprebension - Grade SIx

Childaren

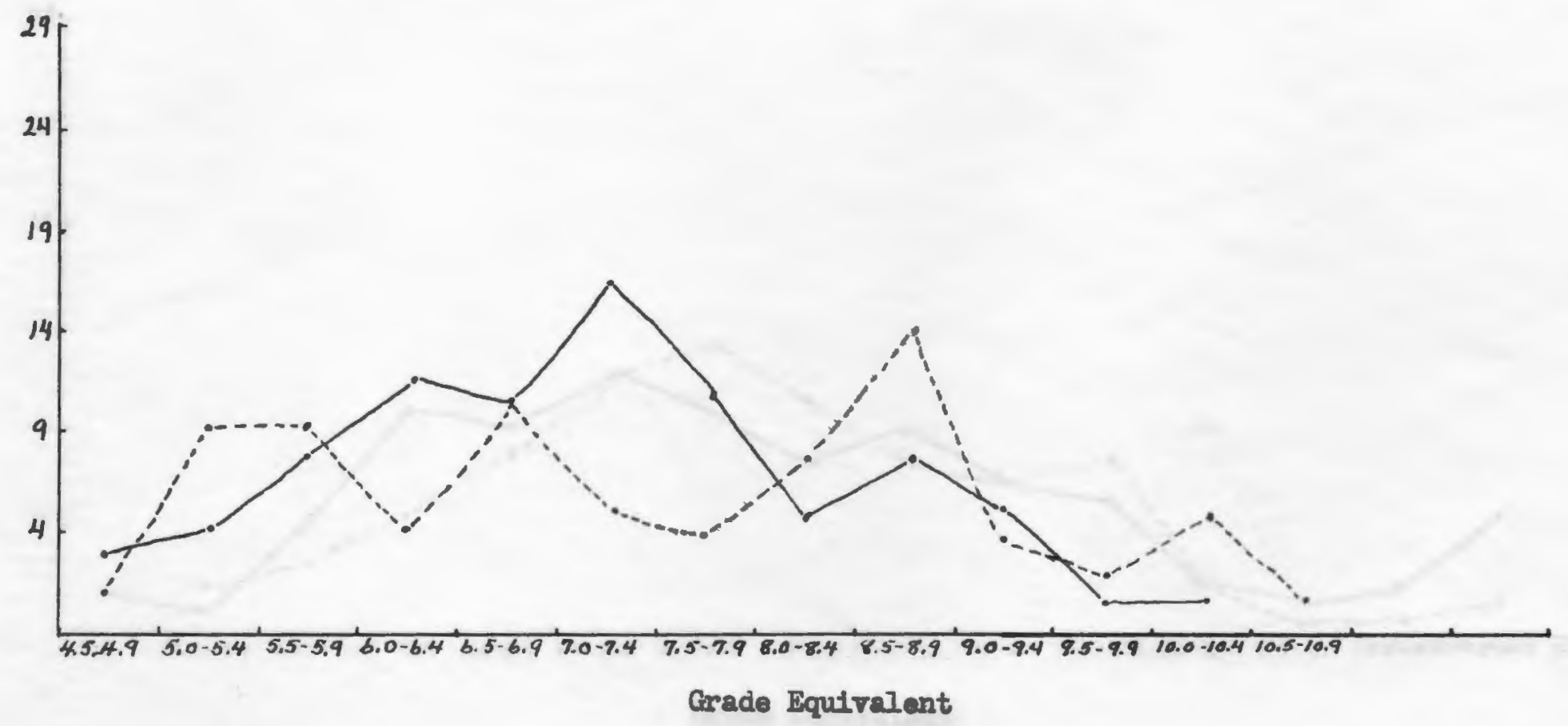

- Permanent Children

- Pransient Children 
Iowa Tests of Basic Skills

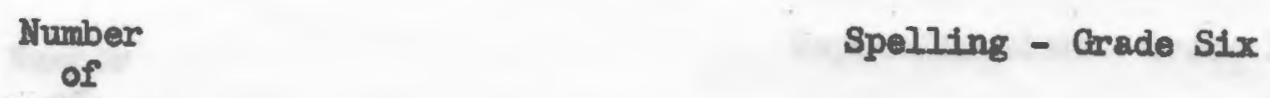

Children

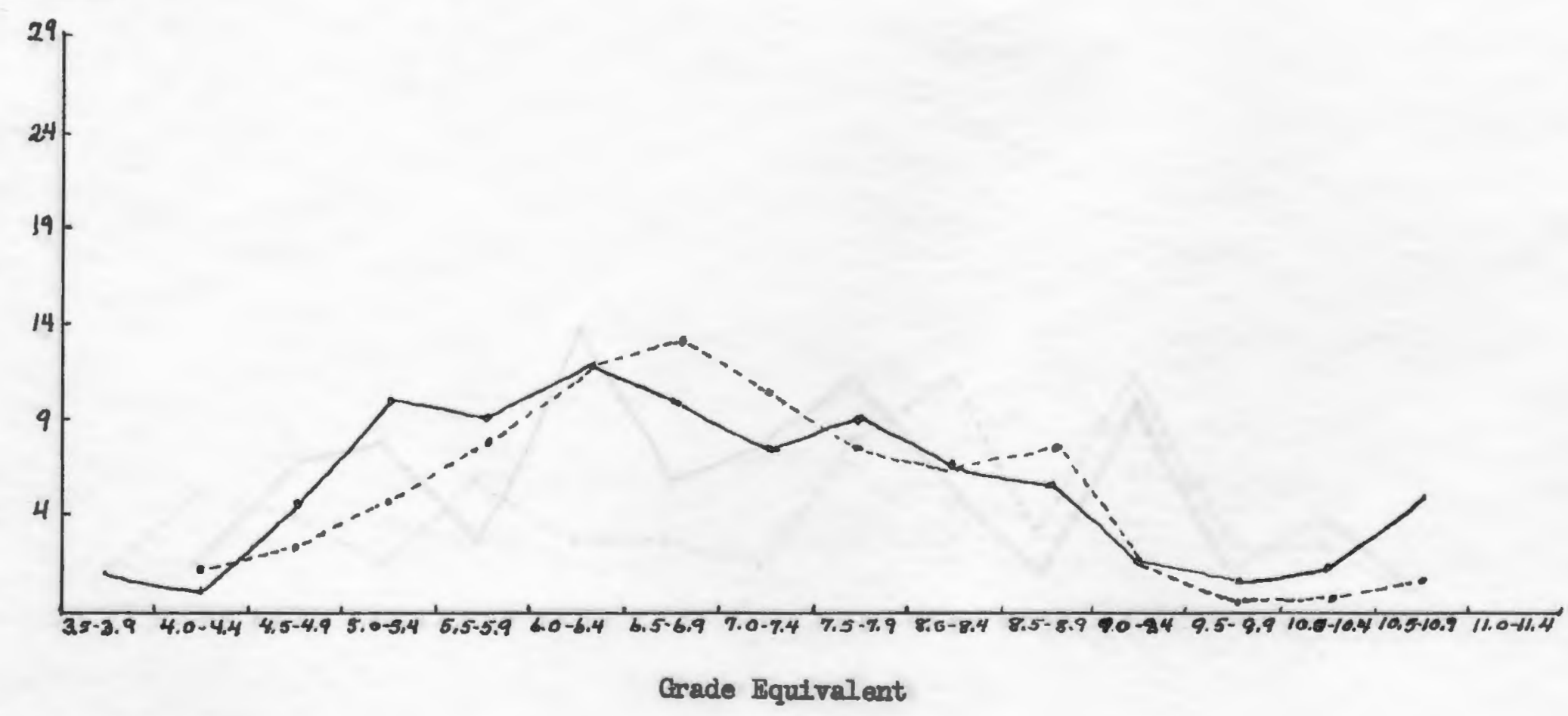

Permanent Children

- . Transient Children 


\section{Iowa Tests of Basic Skedlls}

Number

Capitalization - Grade SIX

of

Children

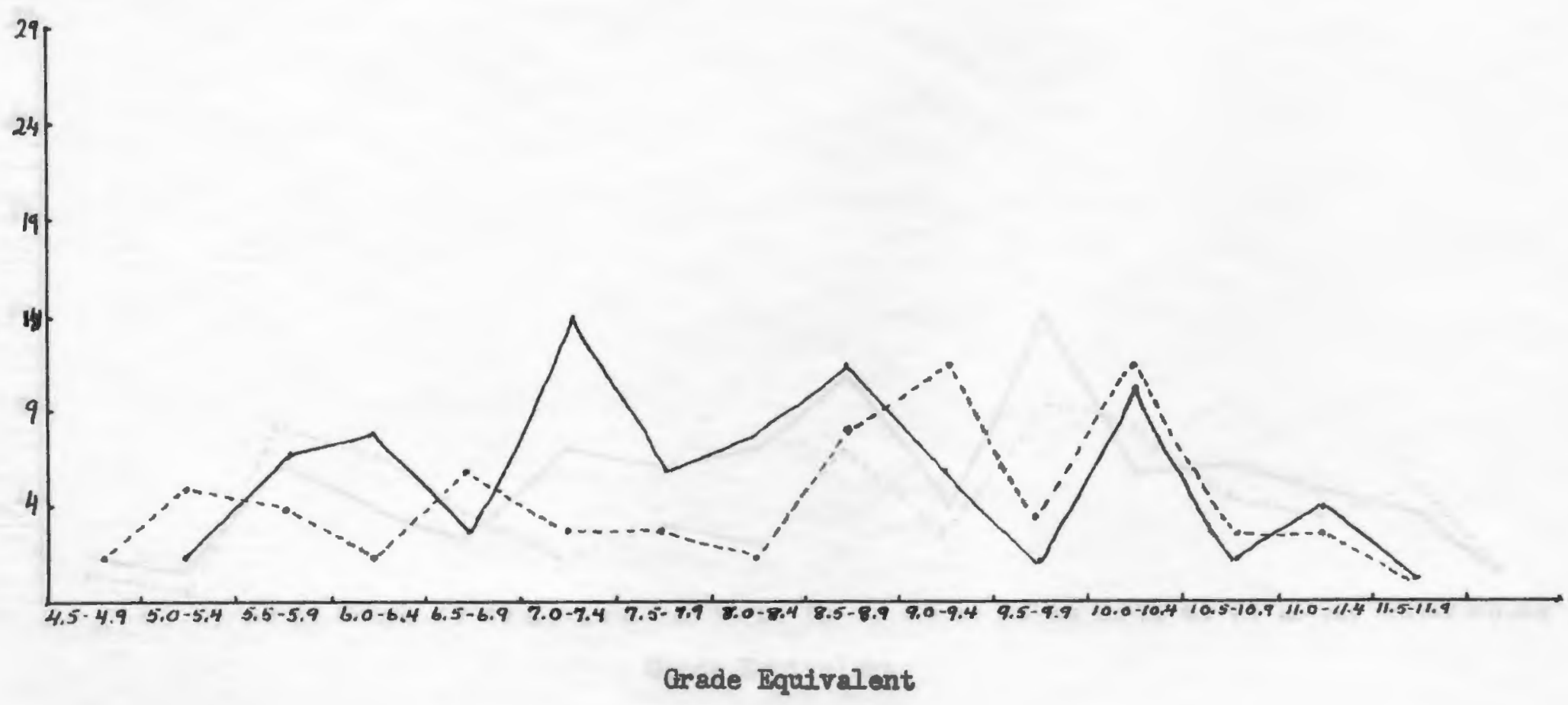

Permanent Children

- . Mransient Children 
Iowa Tests of Basic Skills

Number

of

Panctuation - Grade Six

Children

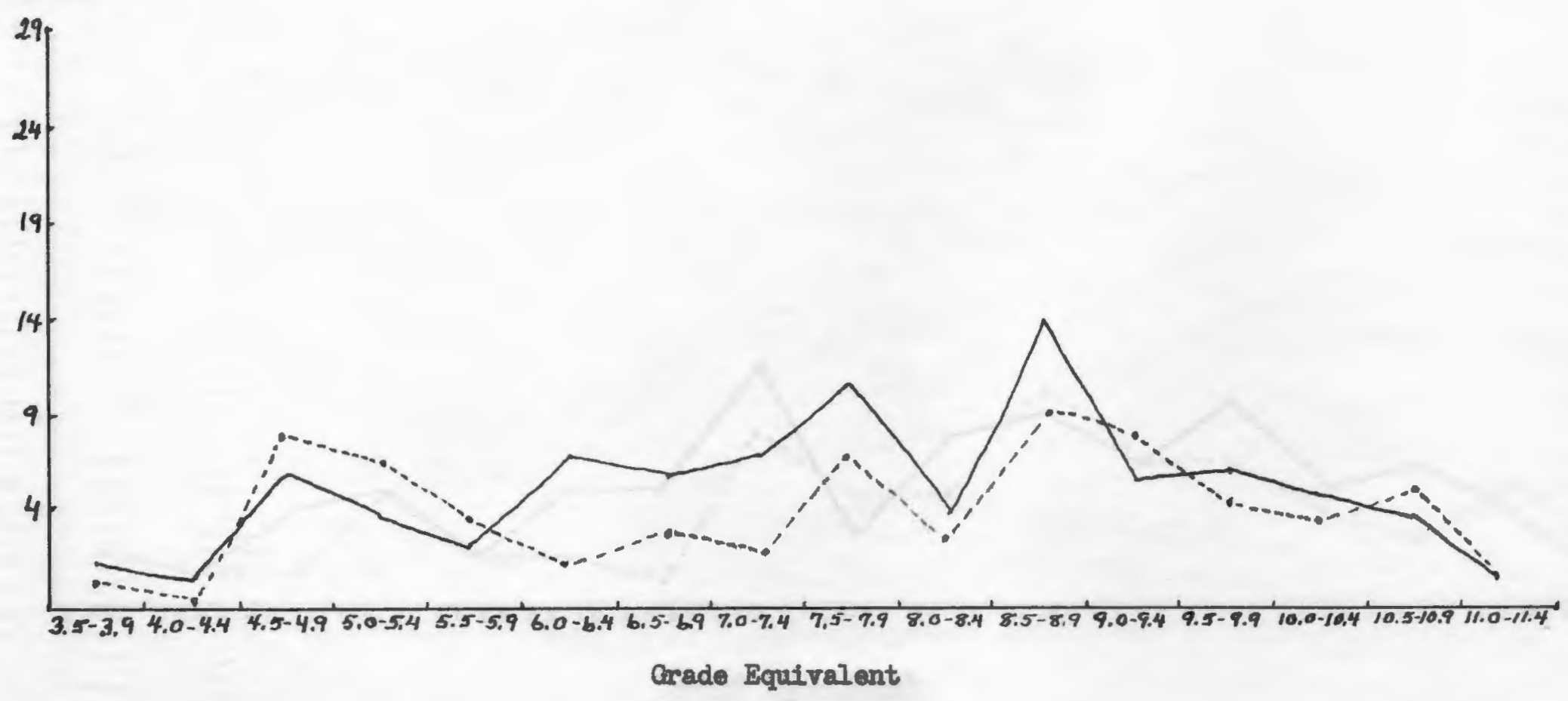

Permanent Children

- . Iransient Children 
Iowa Tests of Basic Skills

Number

$$
\text { of }
$$

Language Usage - Crade Six

Children

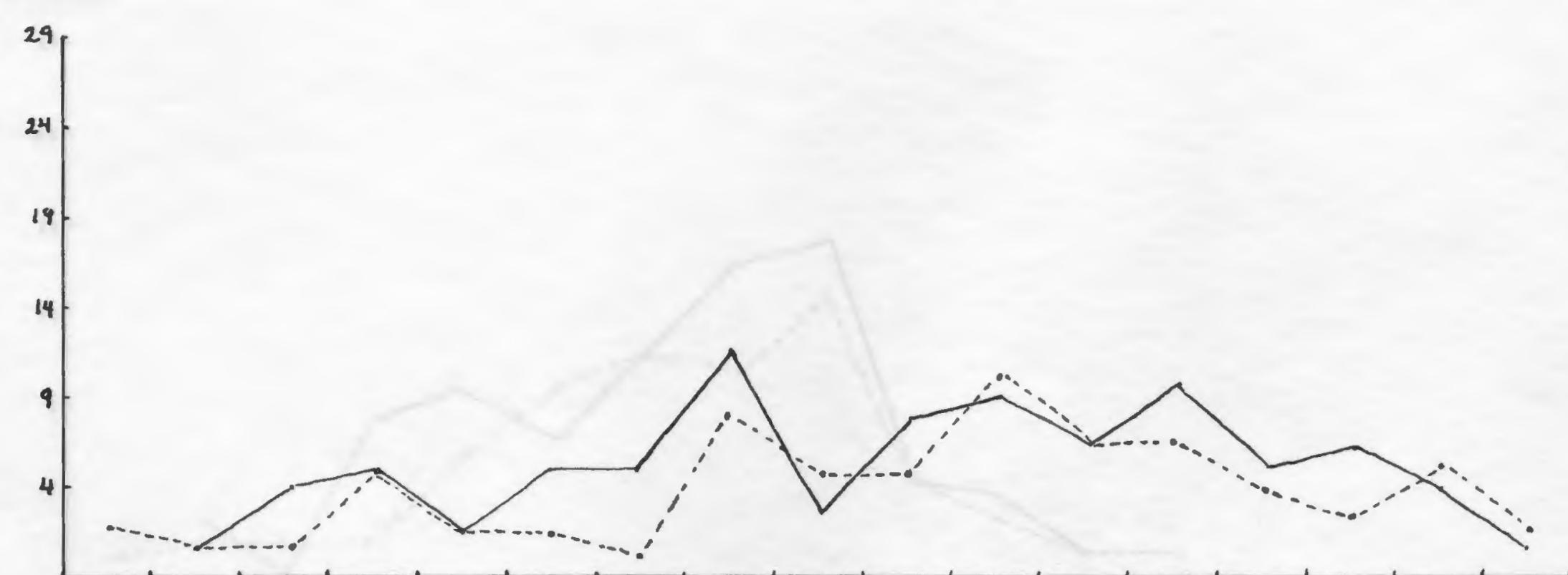

3.0-3.4 3.5-3.9 4.0-4.4 4.5-4.9 5.0-5. 5.5-5.9 6.0-6.4 6.5-6.9 7.0-7.4 7.5-7.9 8.0-7.4 8.5-8.9 9.0-9.4 9.5-9.5 10.0-10.4 10.5-10.9 11.0-11.44

Crade Equivalent

Permanent Children

- . Transient. Children 
Iowa Tests of Basic Skilis

Numbar

of

Mep Reading - Grade Six

Chtldren

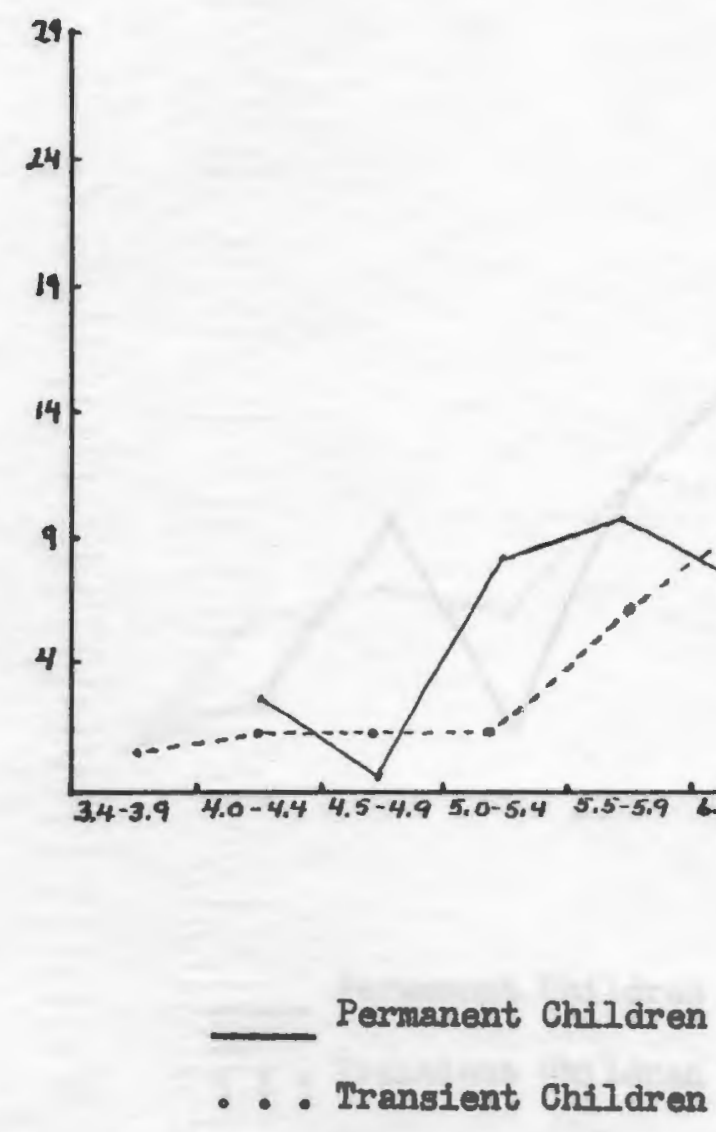

Grade Equivalent 
Iorra Tests of Basic Skill.

Number

Knowledge and Use of Reference Material - Orade Six

of

Chilldren

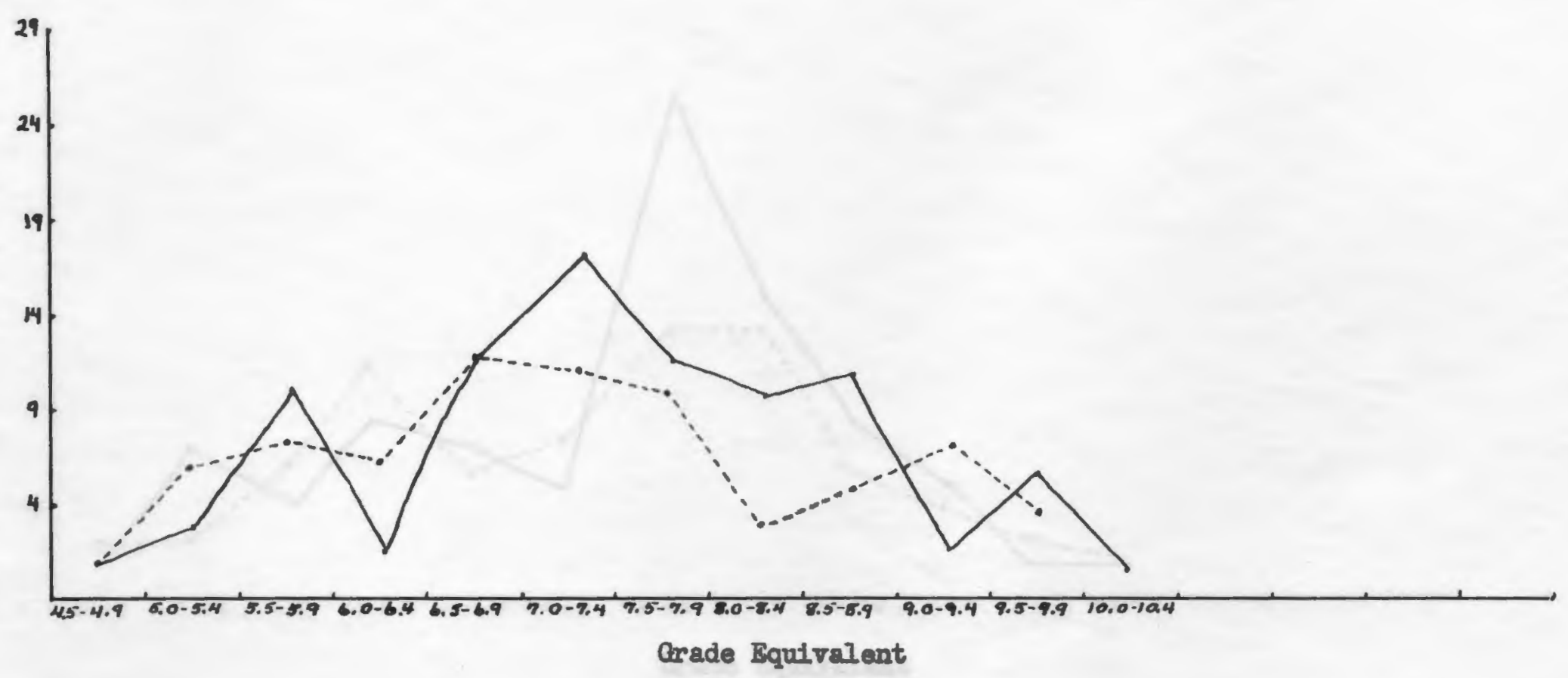

Permanent Childran

... Transient Chilldren 
Iowa Tests of Basic Skills

Number Reading Graphs and Tables - Grade Six

$$
\text { of }
$$

Children

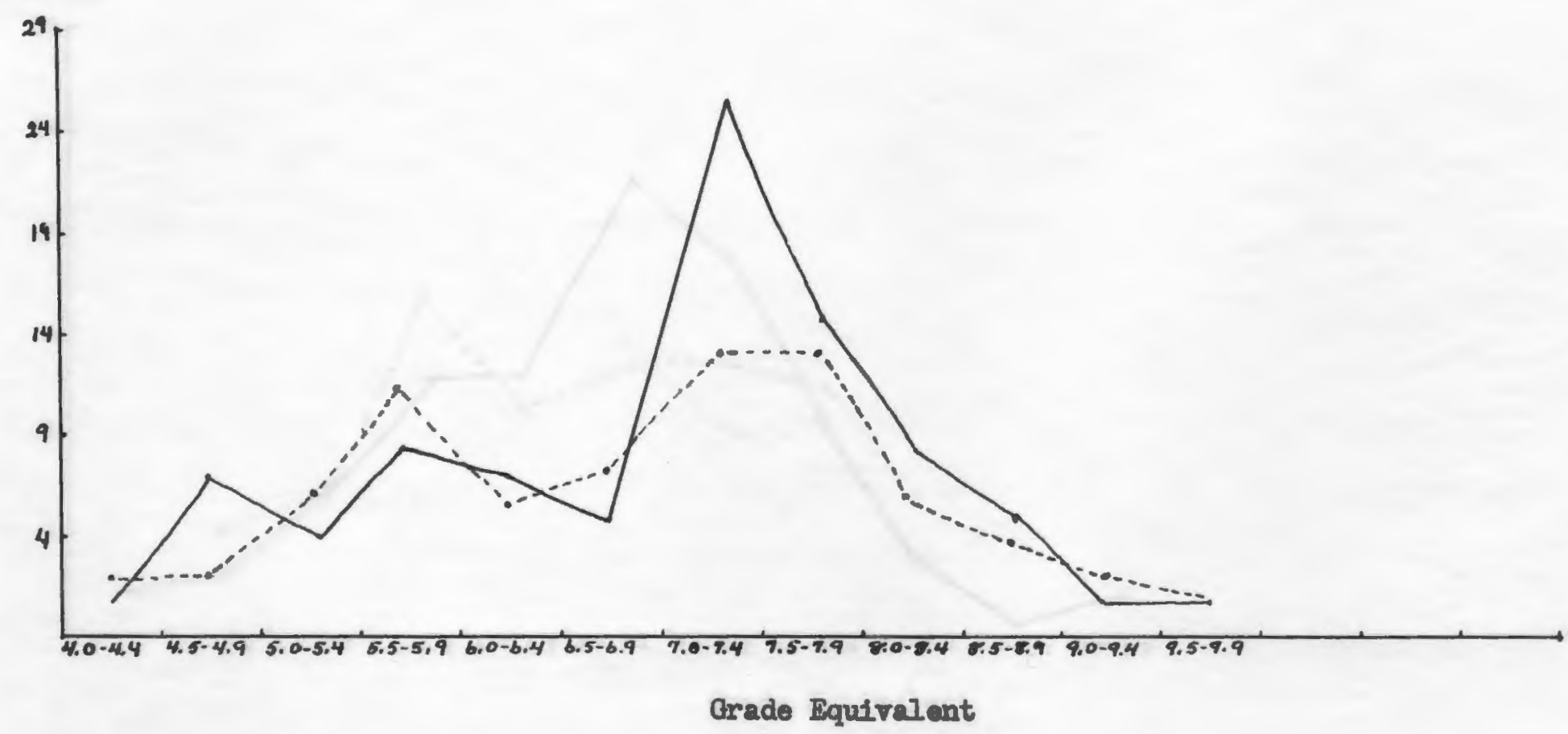

Permenent Children

-.. Iransient Children 
Iowa Tests of Besic Skdils

Number

Arithmetic Concepts - Grade Six

Childran

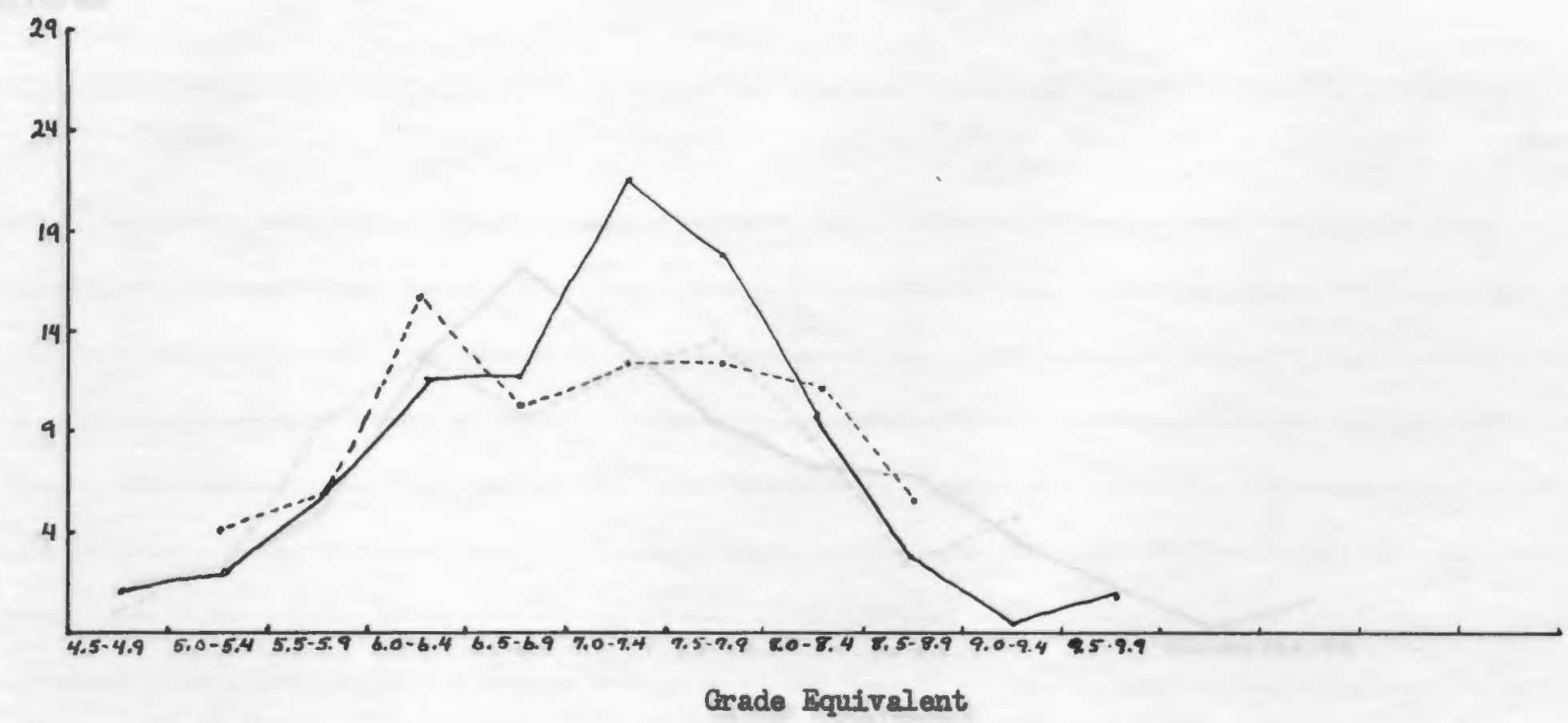

_ Permanent Chtldren

... Transient Children 
Iowa Tests of Basic Skills

Arithmetic Problem Solving

Number

of

Grade Six

Children

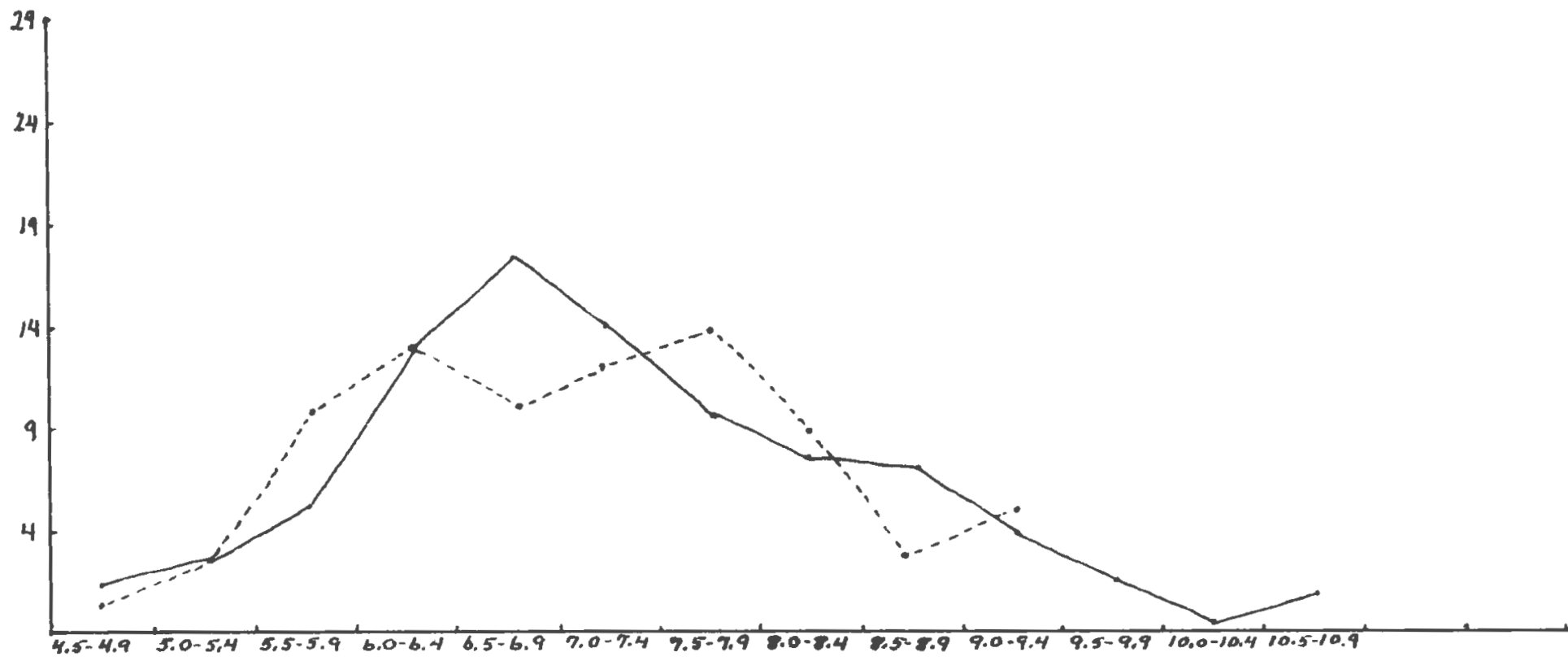

Grade Equivalent

Permanent Children

- . Transient Children 


\section{APPENDIX V. EVAIUATION FORM FOR CHARACTERISTICS}

\section{CHARACTERISTICS OF THE STABLE \\ AND TRANSIENT CHILDREN, IN \\ GRADES FOUR, . FIVE AND SIX}

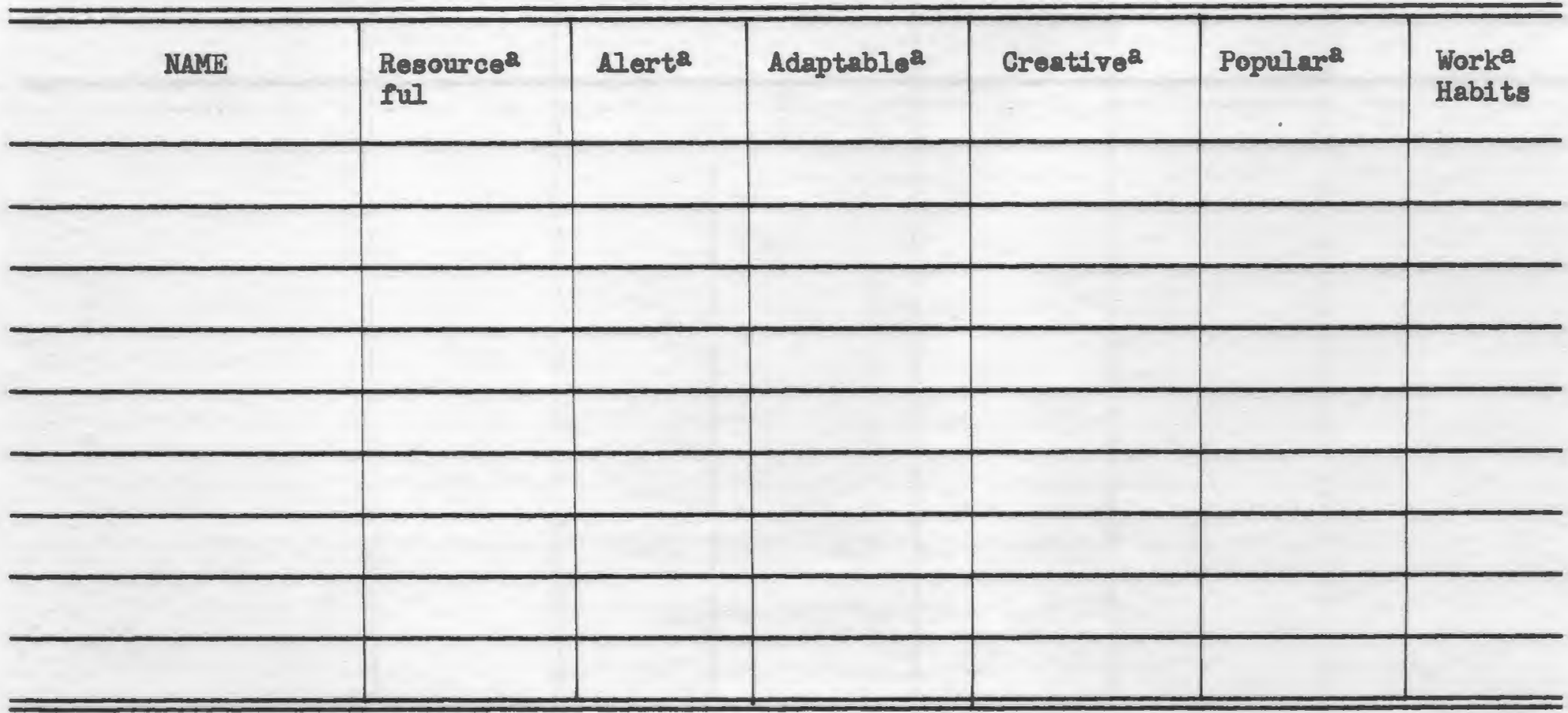

a - to be marked with the following code: Excellent - 1; Good - 2; Fair - 3; Poor - 4 .

b - to be marked as follows: Yes - I; Arerage - A; No - N. 
CHARACTERISTICS - Continued

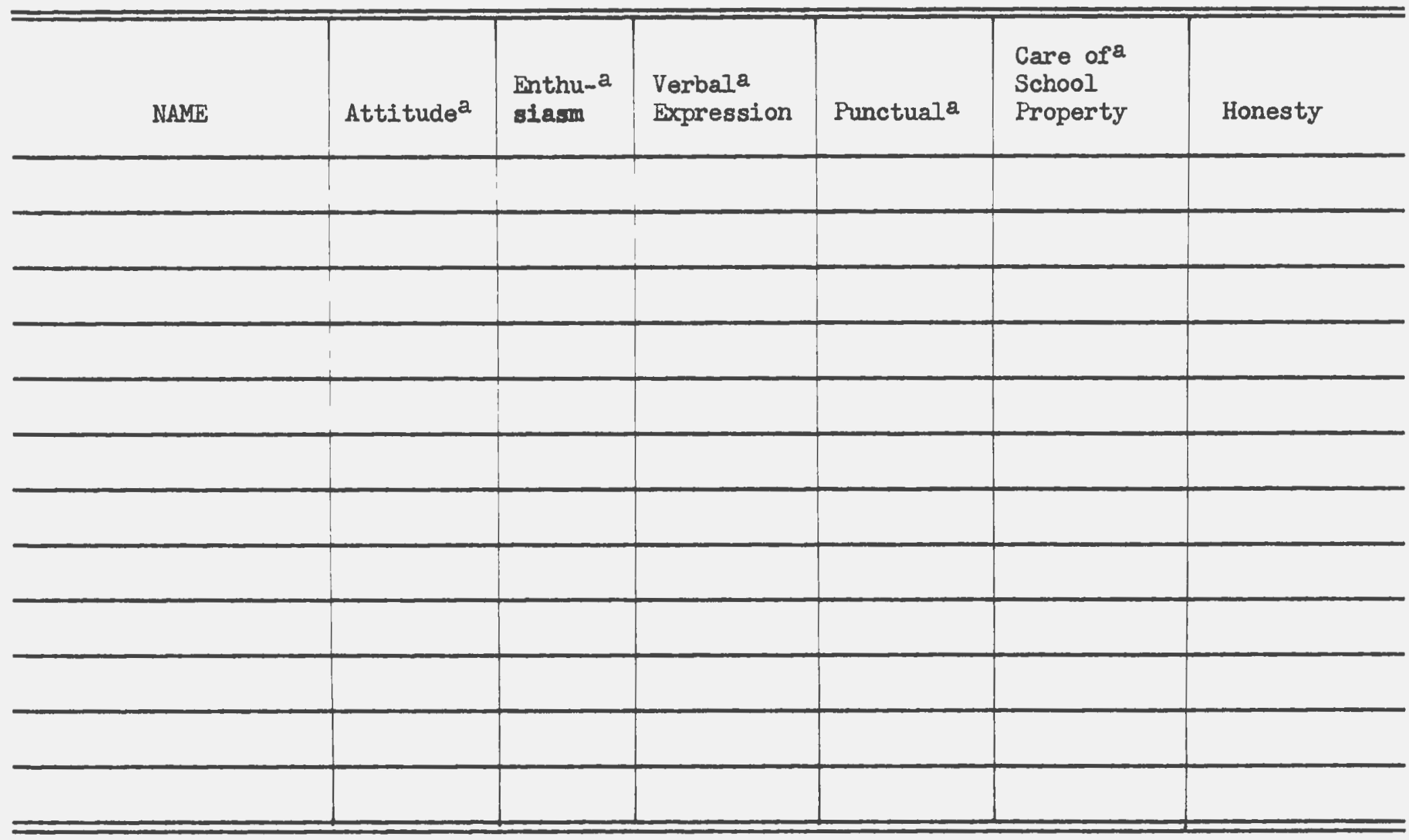


CHARACTERISTICS $=$ Continued

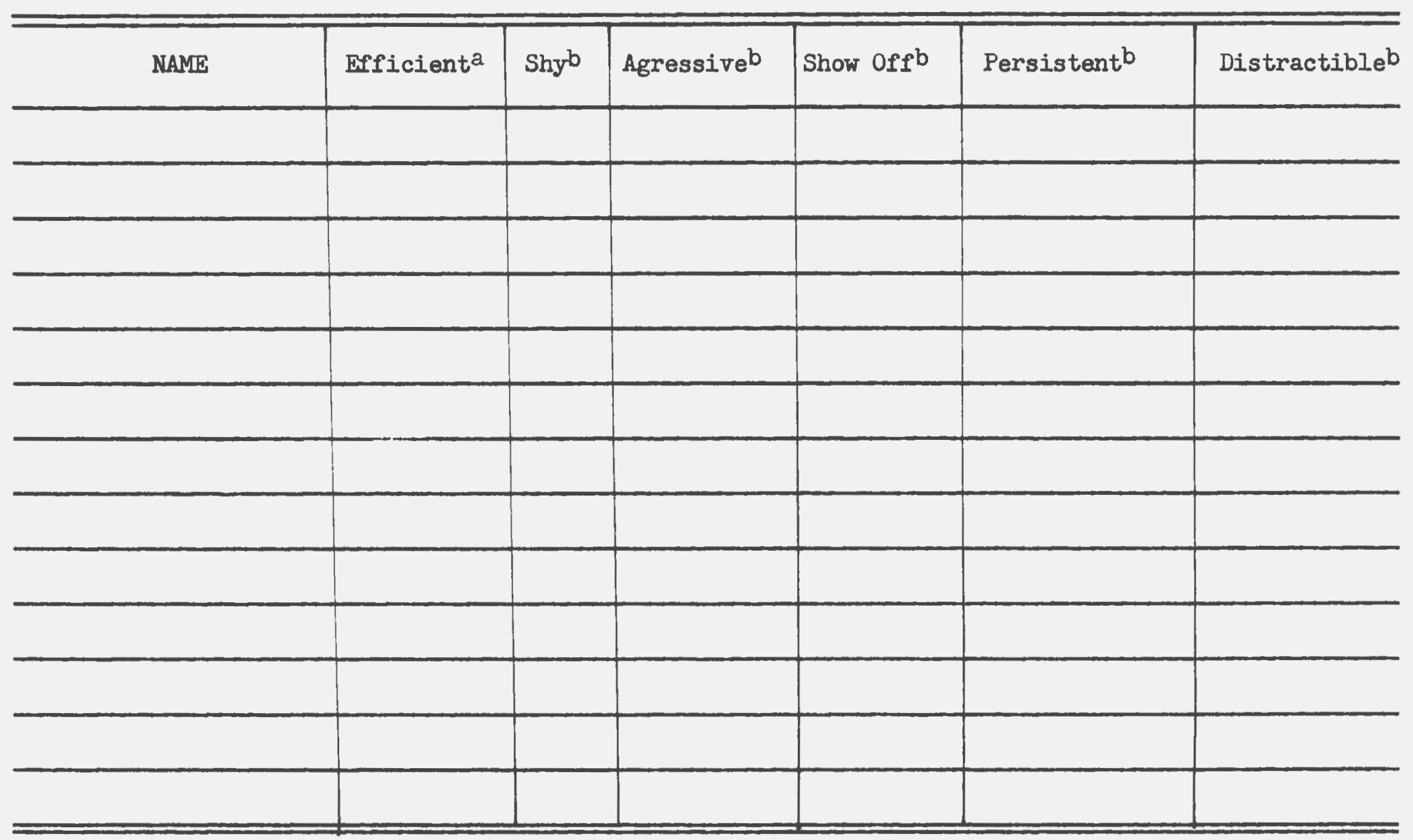


APPENDIX VI. EVALUATION FORM FOR PERTINENT INFORMATION

PERTINENT INFORMATION ABOUT STABLE

AND TRANSIENT, CHTIDREN. IN

GRADES FOUR, FIVE AND SIX

\begin{tabular}{|c|c|c|c|c|c|}
\hline NAME & $\begin{array}{l}\text { Comes From } \\
\text { Broken Homesa }\end{array}$ & $\begin{array}{l}\text { Repeated } \\
\text { Grade }^{a}\end{array}$ & $\begin{array}{l}\text { Enters Outside } \\
\text { Activities }\end{array}$ & $\begin{array}{l}\text { Size for } \\
\text { Ageb }\end{array}$ & $\begin{array}{l}\text { Number of } \\
\text { Sohools Attended }\end{array}$ \\
\hline & & & & & \\
\hline & & & & & \\
\hline & & & & & \\
\hline & & & & 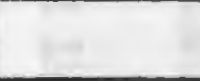 & \\
\hline & & & & & \\
\hline & & & & & (2) \\
\hline & & & 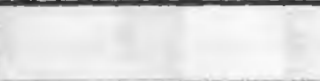 & 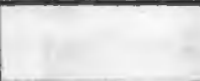 & \\
\hline & & & 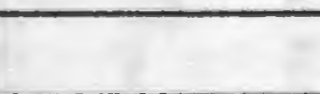 & 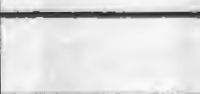 & \\
\hline & & & & 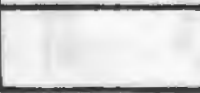 & \\
\hline
\end{tabular}

a - Answer with yes or no.

b - To be marked as follows: Large - I; Average - A; Small - S. 
Blough, Glenn 0. and Dodd, Alan I. "Children Are Their Orm Resources," Childhood Education, Vol. 34, (September, 1958).

Buchrueller, 1. D. When Children Move from School to School, ("Association For Childhood bducation International," 1960.)

"Changing Schools Next Month," Changing Times - The Kiplinger Harazine, August, 1959.

Contemporary Issnes in menentary Education, Education Policies Comision, N. K. A., 1960 .

Davis, Allison. Intelligence and Cultural Differences. Chicago: IIIInois: The University of Chicago Press, 1951 .

The Erening Bulletin (Providence, Rhode Island), Home Edition, Vol. XCIX, Wo. 31, February 7, 1961.

Coldatain, Cortrude and Craubard, Paul. "Integrating the New Child," Childhood Education, Vol. 34, (November, 1958).

Hamnond, Frances P. A Study of the Achievement and Adjustment Patterns of Service-Connected Children. Rhode Island: Universit ty of thode Island, 1960.

Hayes, Elsie. "Changing Noighborhood - Changing Schools," Educational Leadership, February, 1960.

Journal Bulletin 1959 Almanac, A Rhode Island Reference Book. Seventy-Third Annual Edition. Rhode Island: The Providence Journal Company.

Kinball, Solon T. Point of View of an Anthropologist. Paper read at the Department of Elementary Schools Principals N. F. A., Karch, 1961.

Kyte, George C. The Principal at Work. Boston: Ginn \& Company. 
Lane, Bess B. "On the Move", When Children Move from School to School ("Association for Childhood Education International", 1960).

Larsen, Dr. Robert E. New York Times, Section IV-Ell. (September 25, 1955).

Martin, Francis. "Mobility", Childhood Education, Vol. 34, (September, 1958).

McCormack, Patricia. When Moving Prepare Chtldren for Change in Their Environment," The Evening Bulletin (Providence, Rhode Island), Vol. XCIX, No. 36, Home Edition, February 13, 1961.

Newsweek, "The Lag in Brain Power", Vol. IVI, (October 31, 1960).

"North Kingstown Study Stresses Effects of Navy Installations", The Evening Bulletin (Providence, Rhode Island) ApriI 15, 1960.

Phillips, Beeman N. "Impact of Pupil Mobility of the Schools", Educational Administration and Supervision, Vol. 43, (February, 1957).

Potter, Ruth E. "Table VI," Statistical Tables, Rhode Island: Department of Education, 1958-1959.

"Preliminary Census Data", The Evening Bulletin, Vol. XCVIII, No. 130, June 2, 1950 .

Providence Sunday Journal (Providence, Rhode Island), Section N, State News and Features, (September 11, 1960).

Questionnaires to Superintendents in Impact Areas, Personal questionnaires sent out. 1960 .

Rhode Island, Writers Program of the W. P. A. "From Massachusetts line to Connecticut Line", Boston: Houghton Mifflin Company.

Rickover, Vice-Admiral Hyman G. Meet the Press, January 24, 1960. (Television).

School Iife, June, 1957.

Smith, G. Milton, Ph. D. A Simplified Guide to Statistics for Psychology and Education. New York: Finehart \& Company, 1946.

Teacher's Manual, Iowa Tests of Basic Skills, Boston: Houghton Mifflin Company, 1955-1956. 
"Valuation of Property Exempt From Taxation". North Kingstown: Tax Book, 1956.

Wahlquist, Arnold, Campbell, Reller, and Sands. The Administration of Public Education. "Pupil Accounting", New York: The Ronald Press Company, 1952.

Webster's New Collegiate Dictionary, Second Edition, Springfield, Massachusetts: Webster's G. \& C. Merriam Company, 1951.

Weymouth, Laure (Mrs.). Wife of the Captain of the aircraft carrier, Lake Champlain. (Personal Interview.)

White, Colonel Hunter C. Wickford and Its Old Houses. North Kingstown, Rhode Island: Main Street Association, May, 1960. 